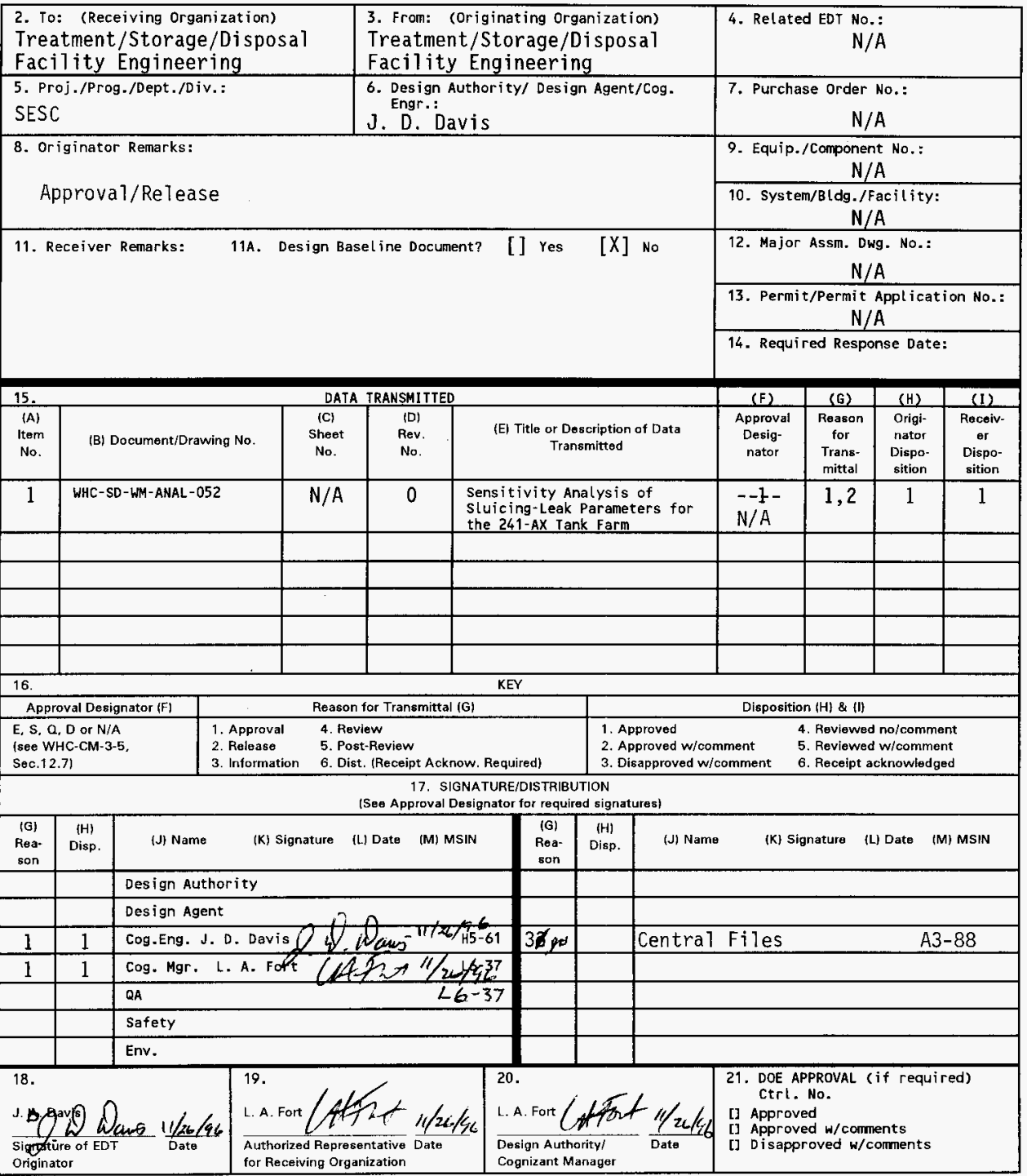

BD-7400-172-2 (05/96) GEF097 


\title{
Sensitivity Analysis of Sluicing-Leak Parameters for the 241-AX Tank Farm
}

\author{
M. G. Piepho ${ }^{1}$ \\ J. D. Davis ${ }^{2}$ \\ K. A. Lindsey \\ M. D. Ankeny \\ M. A. Prieksat
}

'Daniel B. Stephens \& Associates, Inc.

${ }^{2}$ SGN Eurisys Services Corp., Richland, WA 99352

U.S. Department of Energy Contract - BE-ACO6-87ft-10930 DE-AC06-96RL13200 pE

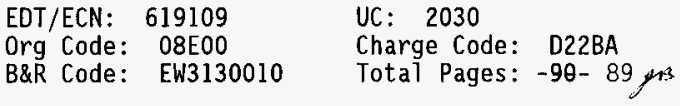

Key Words: Sensitivity analysis, sluicing-leak, 24l-AX Tank farm, recharge rate, groundwater contamination.

Abstract: The scope of this work was to analyze the sensitivity of contaminant fluxes from the vadose zone to the water table, to several parameters. Some of these parameters are controllable. The results were evaluated with respect to their sensitivity to the following types of parameters: hydrostratigraphy and hydraulic properties; volume, duration, and source area of leakage; simultaneous leakage from multiple tanks; pre-existing leaks; barriers to infiltration of meteoric water; and contaminant concentrations and geochemistry.

TRADEMARK DISCLAIMER. Reference herein to any specific commercial product, process, or service by trade name, trademark, manufacturer, or otherwise, does not necessarily constitute or imply its endorsement, recommendation, or favoring by the United States Government or any agency thereof or its contractors or subcontractors.

Printed in the United States of America. To obtain copies of this document, contact: WHC/BCS Document Control Services, P.0. Box 1970, Mailstop H6-08, Richland WA 99352, Phone (509) 372-2420; Fax $(509) 376-4989$.
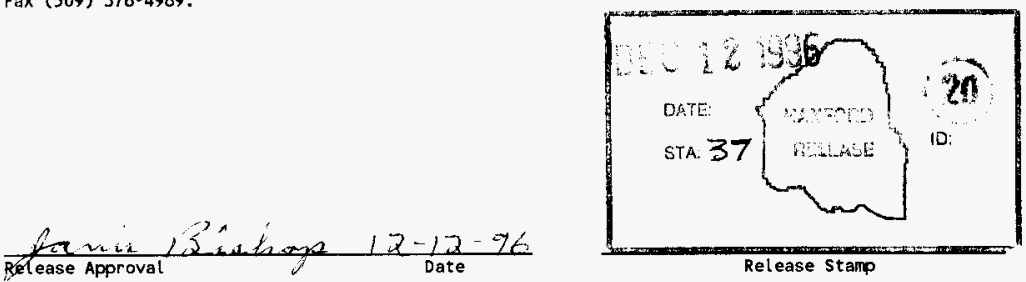

Release Stamp

\section{Approved for Public Release}




\section{SENSITIVITY ANALYSIS OF SLUICING-LEAK PARAMETERS FOR THE 241-AX TANK FARM}

M. G. Piepho'

J. D. Davis ${ }^{2}$

K. A. Lindsey ${ }^{1}$

M. D. Ankeny ${ }^{1}$

M. A. Prieksat ${ }^{1}$

November 1996

Prepared for the U.S. Department of Energy Office of Environmental Restoration and Waste Management

'Daniel B. Stephens \& Associates, Inc.

${ }^{2}$ SGN Eurisys Services Corp.

Richland, Washington 
WHC-SD-WM-ANAL-052, Rev. 0

\section{ACKNOWLEDGMENTS}

The authors would like to acknowledge the contributions that Len Collard of SGN Eurisys Services Corporation made to the analysis, particularly on the subject of gravel corrections to the hydraulic data. The authors also would like to thank Jeff Hertzel of Numatec Hanford Company for obtaining the funding for this work and the U.S. Department of Energy for providing the funding under Contract DE-AC06-87RL10930. 


\section{EXECUTIVE SUMMARY}

Sluicing by pressurized water will be used to remove radioactive and hazardous chemical waste from single-shell tanks (SST) buried beneath the Hanford Site. Because some tanks leaked previously, they can in many instances be expected during the sluicing process either to leak for the first time or to leak again. To date, however, there has been no technically defensible basis for establishing response guidelines to leakage. The issue of how much leakage may be tolerated during the sluicing of SST waste requires resolution before large-scale sluicing of SSTs can proceed. The analyses reported here represent the results of initial work to define a technical basis for operational responses to leakage.

The scope of this work was to analyze the sensitivity of contaminant fluxes, from the vadose zone to the water table, to several parameters. Some of these parameters can be controlled by operational considerations. The results were evaluated with respect to their sensitivity to the following types of parameters:

(P1) Hydrostratigraphy and Hydraulic Properties

(P2) Volume, Duration, and Source Area of Leakage

(P3) Simultaneous Leakage from Multiple Tanks

(P4) Pre-Existing Leaks

(P5) Barriers to Infiltration of Meteoric Water

(P6) Contaminant Concentrations and Geochemistry.

Given that the contaminants are fully mobile in groundwater, the parameters that most affect the flux of contaminants through the vadose zone to the water table were determined to be the following:

- Hydrostratigraphy and Hydraulic Properties

- Volume of Leakage

- Barriers to Infiltration of Meteoric Water.

Of these three, the results were most sensitive to the presence or absence of infiltration barriers and the time of their placement over the 241-AX Tank Farm. The results were also very sensitive to leak volume. For example, if the leak volume increased by a factor of 20 , the affect on groundwater quality, in terms of the amount of contaminant mass reaching the water table, increased by a factor of 400 at $100 \mathrm{yr}$ after sluicing, and by a factor of 40 after $1,000 \mathrm{yr}$.

In contrast to these findings, the results of other sensitivity analyses suggested that the occurrence of simultaneous sluicing leaks would not enhance or amplify the collective effects of multiple, but nonsimultaneous leaks. This finding indicates that there is no reason, from a risk-based perspective, not to permit the simultaneous sluicing of several tanks in a tank farm. 
The results of the sensitivity analyses suggest that contamination from pre-sluicing leaks will reach groundwater before the contamination in a sluicing leak. However, a sluicingleak volume of 8,000 gal would not significantly shorten the travel time to the water table of contaminants in pre-sluicing leaks. In contrast, a much larger sluicing leak of 40,000 gal would appreciably shorten the travel time to the water table of contaminants in pre-sluicing leaks.

In summary, without installation of a surface barrier to the infiltration of meteoric water within the first $30 \mathrm{yr}$ after sluicing, even a leak from sluicing as small as 4,000 gal may be an unacceptable risk to groundwater quality. On the other hand, if the contaminant mass in a sluicing leak is relatively small, then the allowable leakage volume could be much larger. In any case, leakage volumes in excess of $\sim 40,000$ gal would likely significantly enhance transport to the water table of contaminants currently residing in the vadose zone from earlier pre-sluicing leaks.

Because reduction of the infiltration of meteoric water into the tank farms is indicated by results of the sensitivity analyses to be so important to reducing risks to groundwater quality from tank leaks, a summary of the fractional release curves is shown for each barriersensitivity case in Figure ES-1. Also shown for purposes of comparison is the baseline case. The baseline case assumes that a permanent barrier is constructed over the 241-AX Tank Farm $30 \mathrm{yr}$ after sluicing operations cease. This figure is the same as Figure 3-12 in Chapter 3.0.

The figure clearly shows that, from a perspective of reducing risk to groundwater quality, it would be far better to emplace a temporary infiltration barrier immediately after sluicing operations, even if it were only partially effective, than to wait $30 \mathrm{yr}$ to construct a more effective permanent barrier to infiltrating precipitation.

Based on findings of the sensitivity analyses, recommended responses are as follow:

- Obtain better, site-specific hydrogeologic data for the tank farms

- Conduct sluicing operations to minimize the potential leak volumes from sluicing

- Design a temporary surface barrier to infiltrating precipitation that can be emplaced as soon as possible after sluicing of a tank farm

- Evaluate methods of mitigation applicable to sluicing leaks in excess of $\sim 40,000 \mathrm{gal}$

- Estimate contaminant concentrations that could be expected in leaks from specific tanks and perform tank-specific risk analyses to better evaluate the need for early emplacement of an infiltration barrier and/or leak mitigation system. 
WHC-SD-WM-ANAL-052, Rev. 0

Figure ES-1. Fraction of Mobile Contaminant Reaching the Water Table as a Function of Barrier Emplacement Date.

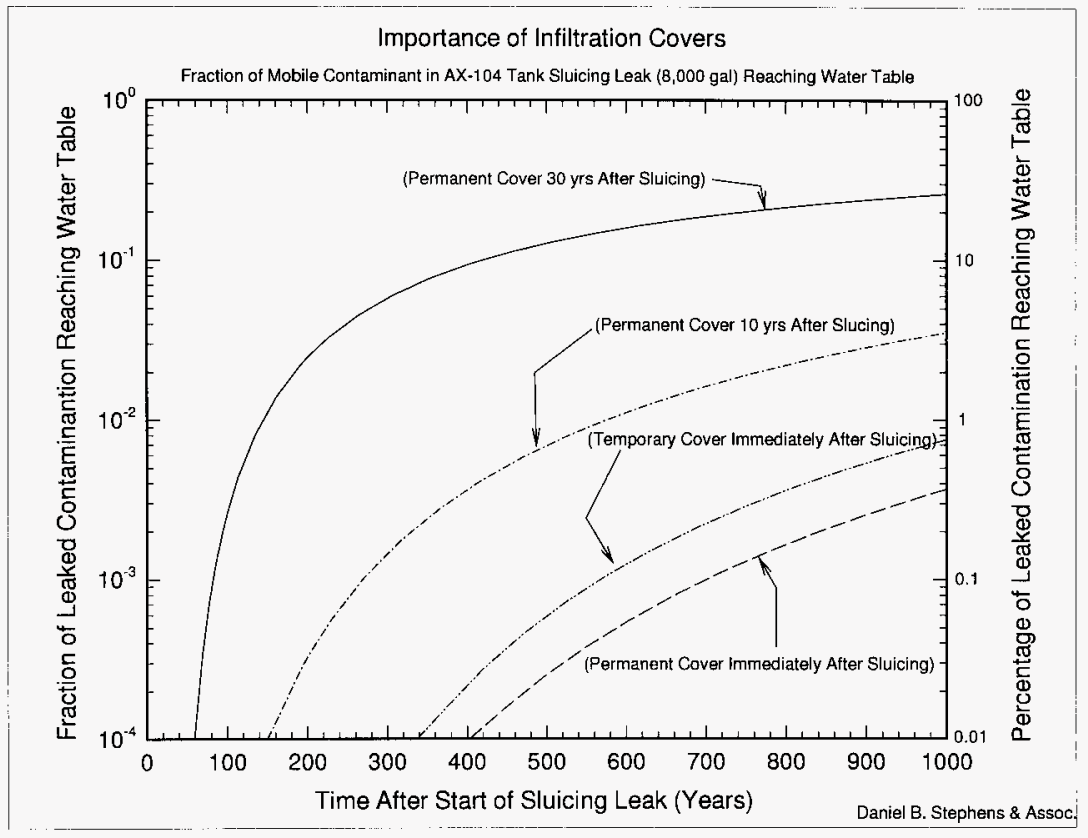

ES-3 


\section{CONTENTS}

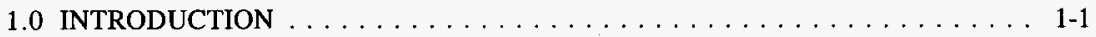

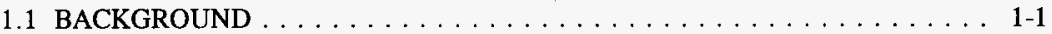

1.2 OBJECTIVE OF ANALYSIS $\ldots \ldots \ldots \ldots \ldots \ldots \ldots \ldots \ldots \ldots \ldots$

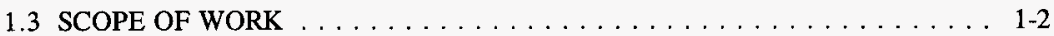

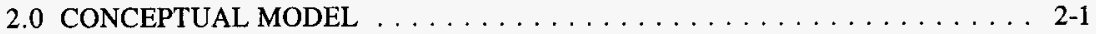

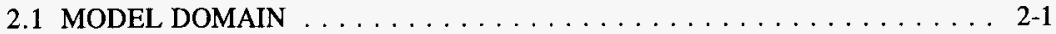

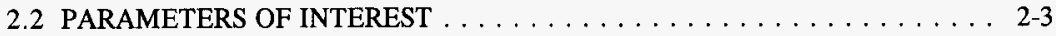

2.2.1 Parameter Group P1 . . . . . . . . . . . . . . . 2-3

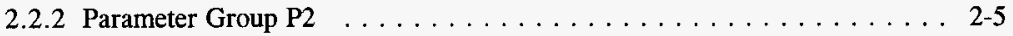

2.2.3 Parameter Group P3 . . . . . . . . . . . . . . . . . 2-6

2.2 .4 Parameter Group P4 . . . . . . . . . . . . . . . . . 2-6

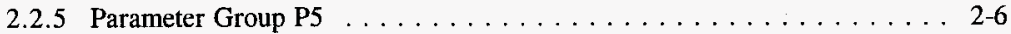

2.2.6 Parameter Group P6 . . . . . . . . . . . . . . . . . . . 2-7

2.3 MATHEMATICAL AND NUMERICAL MODEL $\ldots \ldots \ldots \ldots \ldots \ldots \ldots 2-7$

2.4 PERFORMANCE MEASURE $\ldots \ldots \ldots \ldots \ldots \ldots \ldots \ldots \ldots \ldots . \ldots \ldots$

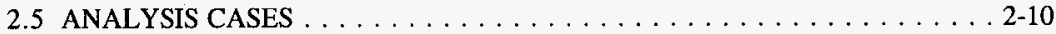

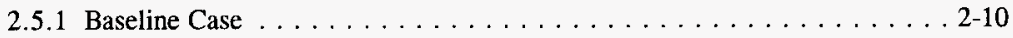

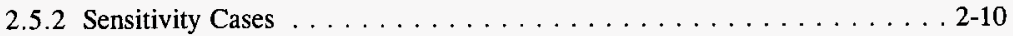

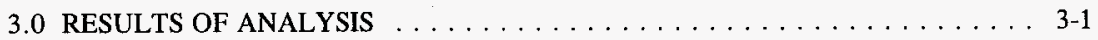

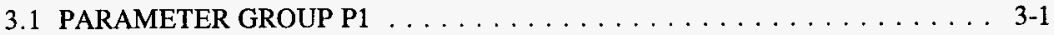

3.1.1 Contaminant Releases to the Water Table for P1 Cases . . . . . . . . . 3-1

3.1.2 Contaminant Concentration Contours for Baseline Case and Case P1-3 . . . 3-3

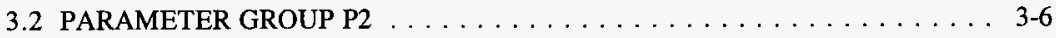

3.2.1 Contaminant Releases to the Water Table for P2 Cases . . . . . . . 3-6

3.2.2 Contaminant Concentration Contours for Case P2-3 (Largest Leak) . . . . 3-10

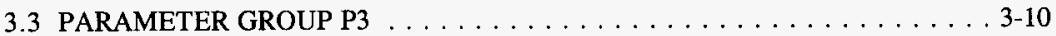

3.3.1 Contaminant Releases to the Water Table for P3 Cases . . . . . . . 3-10

3.3.2 Contaminant Concentration Contours for Case P3-1 (Multiple Leaks) . . . 3-14

3.4 PARAMETER GROUP P4 . . . . . . . . . . . . . . . . . 3-14

3.4.1 Contaminant Releases to the Water Table for P4 Cases . . . . . . . 3-14

3.4.2 Contaminal Concentration Contours for P4 Cases . . . . . . . . . 3-14

3.5 PARAMETER GROUP P5 . . . . . . . . . . . . . . . . . . . 3-17

3.5.1 Contaminant Releases to the Water Table for P5 Cases . . . . . . . . 3-17

3.5.2 Contaminant Concentration Contours for P5 Cases . . . . . . . . . 3-19

4.0 CONCLUSIONS, SUMMARY AND RECOMMENDATIONS . . . . . . 4-1

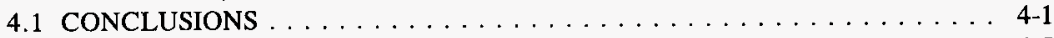

4.2 SUMMARY OF CONCLUSIONS $\ldots \ldots \ldots \ldots \ldots \ldots \ldots \ldots \ldots \ldots \ldots$

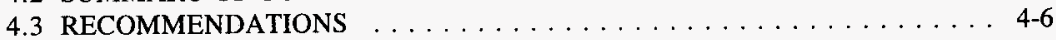




\section{CONTENTS (cont'd)}

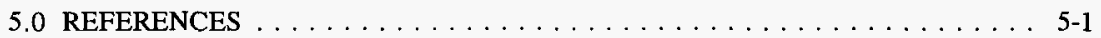

\section{APPENDICES:}

A Geologic Setting of the Hanford Site, 200 East Area, and 241-AX Tank Farm . . . . A-1

B Hydraulic Data and Gravel Corrections $\ldots \ldots \ldots \ldots \ldots \ldots \ldots$ B-1

\section{ATTACHMENT:}

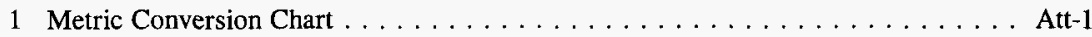

\section{FIGURES:}

2-1. Plan View of the 241-AX Tank Farm and Modeling Domain. . . . . . . . . 2-2

2-2. Simplified Stratigraphy for the 241-A and 241-AX Tank Farms. . . . . . . . . 2-4

2-3. PORFLOW Capabilities. . . . . . . . . . . . . . . . . 2-9

3-1. Fractional Release Curves for Parameter Group P1 Cases. . . . . . . . . . . 3-2

3-2. Concentration Contours for Baseline Case 30 Yrs after Sluicing . . . . . . . 3-4

3-3. Concentration Contours for Case P1-3 (Larger Model Domain) . . . . . . . . 3-5

3-4. Concentration Contours for Baseline Case $1 \mathrm{yr}$ after Sluicing . . . . . . . . . 3-7

3-5. Fractional Release Curves for Parameter Group P2 Cases . . . . . . . . . . 3-8

3-6. Total Mass Release Curves for Parameter Group P2 Cases . . . . . . . . . . . 3-9

3-7. Contaminant Concentration Contours for Case P2-3 (Largest Leak) . . . . . . . 3-11

3-8. Fractional Release Curves for Parameter Group P3 Cases . . . . . . . . . . . 3-12

3-9. Total Mass Release Curves for Parameter Group P3 Cases . . . . . . . . . . . 3-13

3-10. Contaminant Concentration Contours for Case P3-1 (Multiple Leaks) . . . . . . 3-15

3-11. Fractional Release Curves for Parameter Group P4 Cases . . . . . . . . . 3-16

3-12. Fractional Release Curves for Parameter Group P5 Cases . . . . . . . . . 3-18

\section{TABLES:}

4-1. Time After Sluicing Leak for Contaminant to Reach the Water Table $\ldots \ldots \ldots \ldots \ldots$ 4-2

4-2. Percentage of Contaminant Mass Reaching Water Table at Selected Times ........ 4-4 


\subsection{INTRODUCTION}

Sluicing by pressurized water will be used to remove radioactive and hazardous chemical waste from single-shell tanks (SST) buried beneath the Hanford Site. Because some tanks leaked previously, they can in many instances be expected during the sluicing process either to leak for the first time or to leak again. To date, however, there has been no technically defensible basis for establishing response guidelines to leakage. The issue of how much leakage may be tolerated during the sluicing of SST waste requires resolution before large-scale sluicing of SSTs can proceed. The analyses reported here represent the results of initial work to define a technical basis for operational responses to leakage.

A metric-SAE conversion chart (Attachment 1) is provided for convenience.

\subsection{BACKGROUND}

Because leakage in excess of some as-yet to-be-determined amount could result in adverse effects on long-term groundwater quality and may result in eventual exceedance of regulatory standards for groundwater protection, analyses designed to predict the effects on groundwater of leakage during sluicing operations are needed. This report fulfills part of that need.

The 241-AX Tank Farm was chosen for the analysis because the tanks of that farm were extensively sluiced in the past, the farm contains tanks believed to have leaked before or during sluicing, and it contains a tank (241-AX-104) that will be used by the Hanford Tanks Initiative Project (HTI) (WHC 1996) to demonstrate readiness for the first closure of a SST.

\subsection{OBJECTIVE OF ANALYSIS}

The objective of the analysis was to identify, for hypothetical conditions, volumes and rates of leakage from one or more tanks in a representative tank farm, the time required for a specified fraction of the leaked contaminants to reach the uppermost aquifer. The results of the numerical simulations comprising the analysis provide indications, for the specified conditions, of leakage volumes sufficient to promote relatively rapid movement of contaminants to the water table. 


\subsection{SCOPE OF WORK}

The scope of the work reported here was to analyze the sensitivity of contaminant releases from the vadose zone to several parameters, some of which can be controlled by operational considerations. The results were evaluated with respect to their sensitivity to the following types of parameters:

(P1) Hydrostratigraphy and Hydraulic Properties

(P2) Volume, Duration and Source Area of Leakage

(P3) Simultaneous Leakage from Multiple Tanks

(P4) Pre-Existing Leaks

(P5) Barriers to Infiltration of Meteoric Water

(P6) Contaminant Concentrations and Geochemistry. 


\subsection{CONCEPTUAL MODEL}

Conceptual models are the information, simplifications, and assumptions that collectively express our concept of how a system operates and is depicted for purposes of numerical simulation. Principal assumptions and simplifications of the hydrogeologic system represented for purposes of this analysis are as follow:

- The sluicing medium is water and the leaked fluid has the properties of water

- The system is isothermal

- Only single-phase fluid flow and contaminant transport is considered

- The annual rate of infiltration of meteoric water is constant and decreases when an infiltration barrier is added

- $\quad$ No system exists to mitigate potential leaks

- The simulated contaminant is nondecaying and mobile, with a unit concentration in the leaked fluid

- $\quad$ Risk calculations were deferred to a later date when contaminant concentrations in leaked fluid can better be estimated.

\subsection{MODEL DOMAIN}

The domain of the conceptual model was defined to include an area of $100 \mathrm{ft} \times 100 \mathrm{ft}$ at the surface (Figure 2-1), and to extend $273 \mathrm{ft}$ vertically from the land surface to the water table (Figure 2-2). The area thus defined in plan view includes one-quarter of all four tanks in the 241-AX Tank Farm, with each corner of the model domain coinciding with the center of a tank, as shown in Figure 2-1. The actual east-west horizontal distance between the 241-AX tank centers is $90 \mathrm{ft}$. However, a $100 \mathrm{ft}^{2}$ model domain was used as an approximation because a sensitivity case showed that the size of the model domain did not significantly affect the percentage of contaminant mass reaching the aquifer in a specified time. The north-south distance between 241-AX tank centers is $102 \mathrm{ft}$, not $100 \mathrm{ft}$. Both east-west and north-south distances between 241-A tank centers are $102 \mathrm{ft}$, as shown in Figure 2-1. 
Figure 2-1. Plan View of the 241-AX Tank Farm and Modeling Domain.

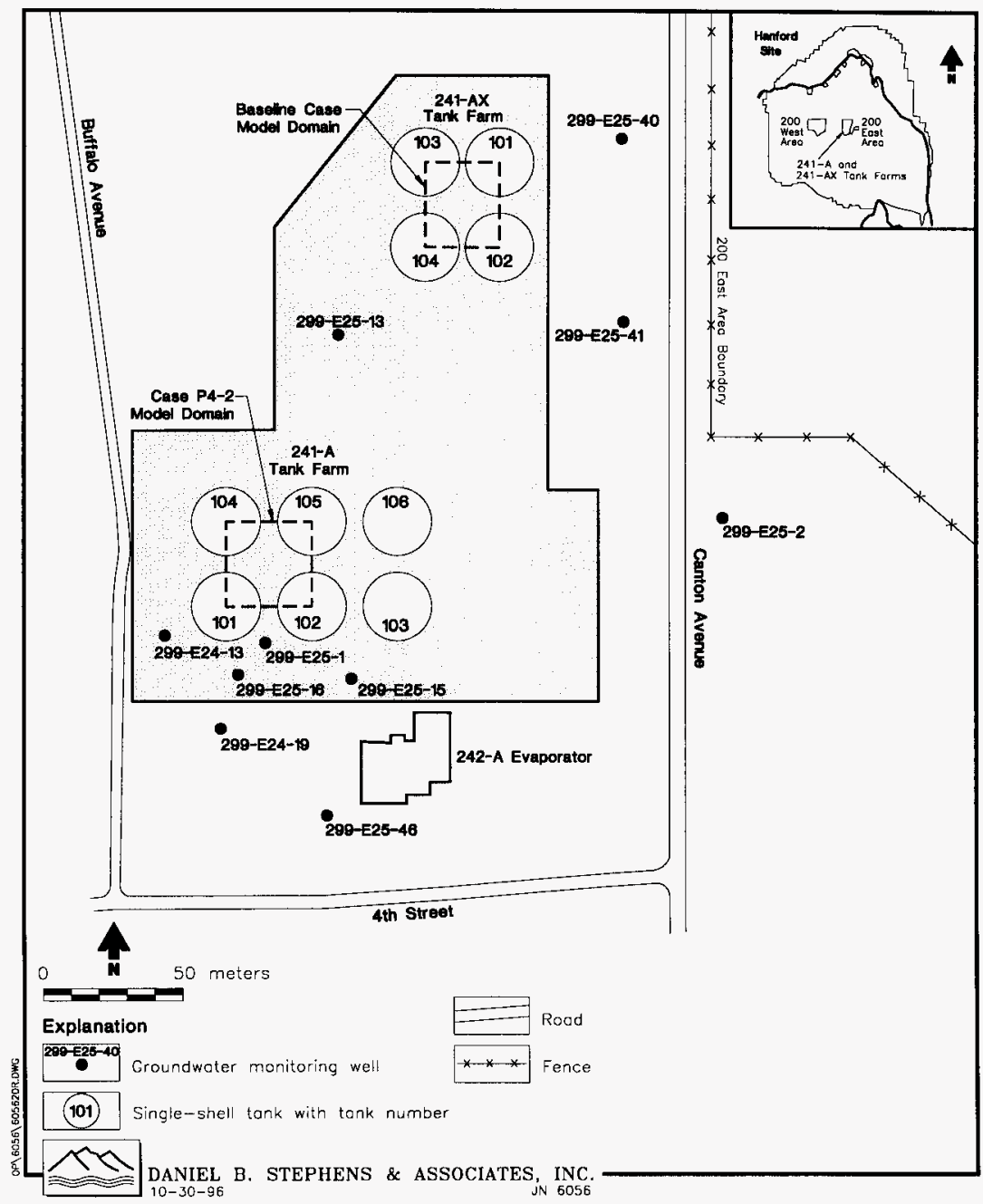


A simplification of the actual stratigraphy (Figure 2-2) at the 241-A and -AX tank farms was used for the model. A more detailed description of the lithologies that comprise the vadose zone beneath the 241-AX Tank Farm is provided in Appendix A, but was not used for the conceptual model because of the short time available to complete the analysis. By simplistically depicting the 241-AX Tank Farm stratigraphy, the four-tank conceptual model could also be used to simulate leaks from four of the six tanks in the 241-A Tank Farm.

A no-flow condition was applied to the vertical boundaries of the model domain. Imposition of a no-flow condition at these boundaries is believed to be conservative with respect to the analytical objectives because horizontal migration of the leaked contaminants would be prevented and vertical migration thereby enhanced.

Initial conditions at the start of sluicing were calculated based on (1) results of a steadystate simulation with an estimated $1 \mathrm{~cm} / \mathrm{yr}$ recharge rate before the 241-AX Tank Farm was built, and (2) an estimated $10 \mathrm{~cm} / \mathrm{yr}$ enhanced recharge resulting from the absence of vegetation and the presence of a graveled surface over the 241-AX Tank Farm since it was built $(\sim 32$ yr ago $)$.

At the time that enhanced recharge was assumed to begin, a $10 \%$ moisture content was estimated for the backfill around the tanks based on construction practices for compacting backfill soil. This increased moisture content was not by itself expected to significantly affect leaks from sluicing because any potential sluicing-water leak would in any case be preceded by $32 \mathrm{yr}$ with relatively high infiltration of precipitation. Conditions immediately before the start of sluicing operations are considered to be the initial conditions for the sluicing-water leak simulations.

\subsection{PARAMETERS OF INTEREST}

The parameters of interest whose values were varied in the sensitivity analyses were grouped into six categories, as listed in Section 1.3. The parameters that comprise each of these six categories are discussed in the sections that follow. Specific values used for each parameter are provided in the sections that describe the simulation cases.

\subsubsection{Parameter Group P1}

A simplified ("pancake or layercake") stratigraphy with best-estimate values for hydraulic properties of major lithologic units was used for most of the cases simulated for Parameter Group P1. Hydraulic properties of each lithology were estimated because no sitespecific hydraulic-properties data were available for the 241-AX Tank Farm. The values assigned for hydraulic properties were based on physical property data from the proposed grout facility to the east of the 241-A Tank Farm complex and data for sediment particle-size distributions from the 241-AX Tank Farm drywells. Detailed descriptions of the geologic and hydrologic data are given in Appendices A and B. 
Figure 2-2. Simplified Stratigraphy for the 241-A and 241-AX Tank Farms.

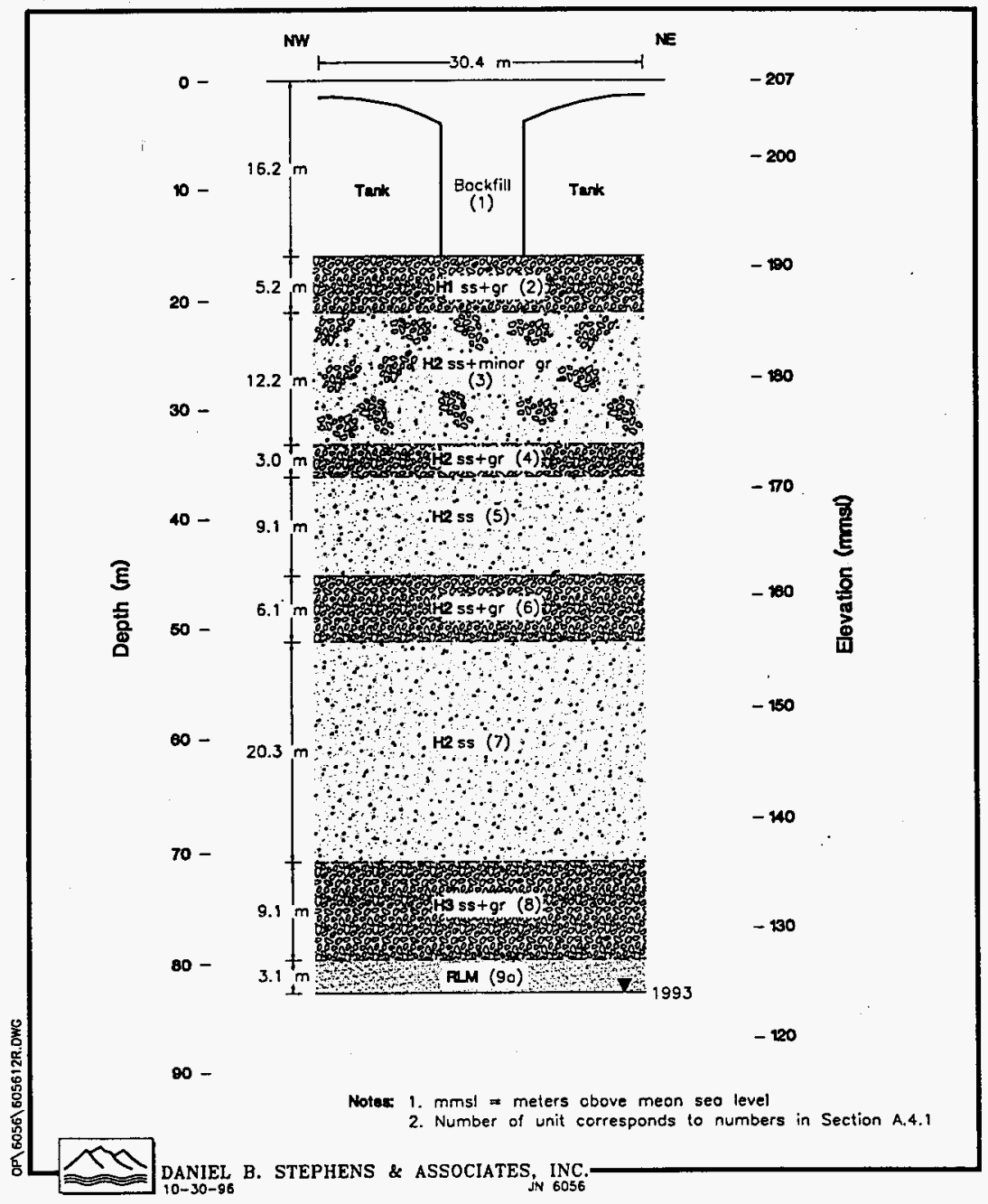


A sensitivity case with alternative hydraulic properties was analyzed for the same simplified stratigraphy to evaluate the relative importance of hydraulic properties data. The sensitivity case used hydraulic properties reported for the grout performance assessment (Piepho 1994; Kincaid et al. 1995). These data were based on averages for the entire Hanford Site.

In another sensitivity case, corrections for the effects of gravel on the pore space available for flow were neglected to quantitatively evaluate the effects of this correction factor on groundwater flow and contaminant transport. Because the model domain was relatively small (100 ft $\times 100 \mathrm{ft}$ in plan view), a larger model domain was used in an additional sensitivity case. This additional case evaluated effects on the vertical flux of the additional area available for lateral flow.

\subsubsection{Parameter Group P2}

Four values were assigned for the amount of fluid assumed to leak as a result of waste sluicing operations in the 241-AX Tank Farm: (1) 4,000 gal (the average value used by Jacobs Engineering in the Tank Waste Remediation System (TWRS) Environmental Impact Statement (EIS) (DOE and Ecology 1996), (2) 8,000 gal (minimum detectable leak [Iwatate 1996]), (3) 40,000 gal (Lowe 1993), and 160,000 gal (worst reasonable case for Tank 241-AX-101 if the maximum tank leak is initiated by sluicing and is not mitigated).

The duration of leakage for volumes of $\leq 40,000$ gal was assumed to be $0.1 \mathrm{yr}$ $(\sim 5 \mathrm{wk}$ ). One sensitivity case evaluated a leak duration of 6 mo, rather than $5 \mathrm{wk}$. The 160,000-gal leak was assumed to occur during $0.4 \mathrm{yr}$ (about $5 \mathrm{mo}$ ). The results of the simulations were not expected to be sensitive to the duration of leakage provided the duration was $\leq 1 \mathrm{yr}$ and the duration simulated was much longer than $1 \mathrm{yr}$.

Most simulation cases assumed that the leaks emanated from a source whose dimensions equaled that of one cell of the numerical grid $(\sim 2 \mathrm{~m} \times 1.5 \mathrm{~m} \times 1 \mathrm{~m})$.

One sensitivity case considered a much larger leak area, the area equivalent to the cells representing 180 degrees arc for a tank perimeter; in other words, a leak was simulated as emanating from half the tank circumference. The large $(160,000$-gal $)$ leak was assumed to occur over an area equal to the dimensions of three cells of the numerical grid $(2 \mathrm{~m} \times 5.5 \mathrm{~m} \mathrm{x}$ $1 \mathrm{~m})$.

Local symmetry was assumed for the conceptual model domain. Consequently, all tank leaks were assumed to be located at the boundaries of the model domain, and only one-half of each tank and tank leak needed to be modeled. The other half outside of the modeling domain was assumed to be essentially symmetrical with the half within the modeling domain. 


\subsubsection{Parameter Group P3}

Most simulations focused on a leak from a single tank to predict differences in fluxes and travel times resulting from various leak volumes. However, the effects of simultaneous leaks from more than one tank were also evaluated. One case was simulated in which two tanks were assumed to have leaked 8,000 gal each. Another case was simulated in which all four tanks in the 241-AX Tank Farm were assumed to be leaking simultaneously. In this instance, Tank 241-AX-101 was assumed to leak 40,000 gal and the other three tanks were assumed to leak 8,000 gal each.

\subsubsection{Parameter Group P4}

The effects of sluicing leaks on the mobility of contaminants in pre-sluicing leaks in the 241-A and -AX tank farms were also evaluated. Operations records (ICF KH 1994) for the 241-AX Tank Farm indicate that Tank 241-AX-104 leaked 8,000 gal in 1977 and Tank 241-AX-102 leaked 3,000 gal in 1988. The pre-sluicing leaks of the 241-AX tanks were simulated by assuming additional leakage and, alternatively, no additional leakage from sluicing operations.

Tank 241-A-105 in the tank farm adjoining the south end of the 241-AX Tank Farm was simulated to evaluate the effects of a large-volume leak; i.e., the 160,000 gal reported to have leaked from Tank 241-A-105 in 1965 (ICF KH 1994). This large leak was modeled using essentially the same conceptual model that was used to evaluate the effects of 241-AX Tank Farm leaks. The four-tank conceptual model used to simulate the 241-AX Tank Farm leaks was simply shifted south, to include the corners of tanks 241-A-105, -A-106, -A-102, and $-\mathrm{A}-103$.

\subsubsection{Parameter Group P5}

Ten $\mathrm{cm} / \mathrm{yr}$ of precipitation were assumed to infiltrate into the tank farms during the $30 \mathrm{yr}$ after sluicing began. Thirty years after the start of sluicing, installation of a barrier to infiltration was assumed. This was depicted by reducing the recharge rate to $0.05 \mathrm{~cm} / \mathrm{yr}$. One sensitivity case assumed that a temporary infiltration barrier was installed immediately after sluicing ended in the 241-AX Tank Farm. To evaluate the effects of delaying barrier installation, another sensitivity case assumed that the temporary barrier was installed over the tank farm about $10 \mathrm{yr}$ after completing sluicing operations.

A final sensitivity case for this parameter group simulated the effects of a temporary barrier installed immediately after the completion of sluicing operations, but assumed the barrier to be only $90 \%$ effective, thus allowing $1 \mathrm{~cm} / \mathrm{yr}$ of meteoric water to enter the tank farms. The intent of this sensitivity case was to simulate less-than-optimal performance of a partial barrier designed to allow continued access to the tanks. 


\subsubsection{Parameter Group P6}

To focus this portion of the sensitivity analysis on factors affecting groundwater flow rather than on factors affecting the chemistry of contaminant release and transport, only a generic, mobile contaminant was considered. Such an approach generally can be considered to be conservative because the initial and peak concentrations of a fully mobile contaminant would reach the water table before the corresponding concentrations of a contaminant retarded by sorption onto soil particles.

An actual, inventory-based volume and concentration of a specific contaminant species was not used because the objective of Parameter Group P6 sensitivity analyses was not to calculate risk, but to evaluate effects on the water table from sluicing leaks and the factors affecting groundwater flow in the vadose zone. A unit concentration was used for the generic contaminant in the sluicing-water leak. The value assigned for the distribution coefficient $\left(\mathrm{K}_{\mathrm{d}}\right)$ was zero (i.e., transport of the contaminant was not retarded by sorption).

For sensitivity cases that considered the effects of leaks which pre-dated sluicing-water leaks, a unit concentration was assigned to the pre-sluicing leaks; a much smaller contaminant concentration of 0.001 was assigned to the subsequent sluicing-water leaks. A 1000:1 ratio was used because the concentrations of mobile contaminants in a sluicing-water leak would be expected to be significantly less than concentrations of mobile contaminants in the waste that previously leaked from the tank. A sluicing-water leak would likely drive contaminants downward in sediments affected by previous leaks. Hence, contaminants from pre-sluicing leaks generally would be expected to reach the water table before those from sluicing-water leaks.

Longitudinal and transverse dispersivity coefficients of $1 \mathrm{~m} / 0.1 \mathrm{~m}$ were assigned to eliminate numerical dispersion and to depict the dispersive nature of an expanding contaminant plume. These values were considered to be reasonable minimum values, but they could be larger for actual contaminant plumes. The use of larger coefficient values would expand the

area of contamination relative to that which was simulated, resulting in contamination reaching the water table sooner.

\subsection{MATHEMATICAL AND NUMERICAL MODEL}

PORFLOW (a trademark of Analytic and Computational Research, Inc.) technical software was used for the sensitivity analyses of sluicing leak parameters (Runchal and Sagar 1993). PORFLOW is being used by TWRS at the Hanford Site. The software is being used to analyze the hydraulic properties of alternative materials proposed to fill the SSTs after waste retrieval, and to analyze movement of contaminants through the vadose zone for the HTI and TWRS vadose zone characterization projects. Consequently, to maintain consistency and establish a seamless interface with these projects, PORFLOW was selected to perform the analyses reported here. 
PORFLOW is a comprehensive mathematical model for multidimensional analysis of fluid flow, heat transfer, and mass transport of multiple contaminant species in geologic and man-made media. The media may be anisotropic and heterogeneous, and may contain distinctive, embedded elements that depict discrete fractures, boreholes, or sources and sinks for flow or contaminants. The physical processes simulated by PORFLOW are depicted in Figure 2-3.

PORFLOW relies on an inherently mass-conservative numerical method to solve complex mathematical equations. The software can accommodate three-dimensional cartesian or cylindrical geometry, transient or steady-state flow, confined or unconfined aquifer conditions, fully or partially saturated porous media, single or multi-phase systems, dynamically active phase changes between liquid and solid or liquid and gaseous phases, buoyancy effects due to density variations, and decay chains with up to four members.

The software offers a choice of basis functions for integration of equations, alternate methods for solution of the matrix of equations, options to solve any or all of the governing equations, and dynamic coupling between fluid flow, heat transfer, and mass transport. PORFLOW has been extensively peer reviewed, tested, documented, and approved for use at Hanford and other DOE sites by the U.S. Environmental Protection Agency and Washington State Department of Ecology. Capabilities of the software have been documented by the U.S. Nuclear Regulatory Commission (Runchal and Sagar 1993).

\subsection{PERFORMANCE MEASURE}

The performance measure chosen to evaluate the results of each sensitivity case was the time required for $0.1 \%$ of the leaked contaminant mass (from either sluicing leaks or presluicing leaks) to reach and enter the water table. The fraction of leaked contaminant reaching the water table was plotted for the entire interval of time that was simulated $(1,000 \mathrm{yr})$. Consequently, results are portrayed not only in terms of the singular result ( $0.1 \%$ flux mass) for the performance measure, but as a flux history, as well. Moreover, the times required for $1 \%$ and $10 \%$ of the leaked contaminant mass to reach the aquifer were also of interest and are shown.

The calculation of time required for $0.1 \%$ of the leaked contaminant mass to enter the uppermost aquifer differs from a simple travel time calculation in that consideration of the effects of diffusion and dispersion are included in the calculation of contaminant flux, both for pre-sluicing leaks and sluicing-water leaks. 
WHC-SD-WM-ANAL-052, Rev. 0

Figure 2-3. PORFLOW Capabilities.

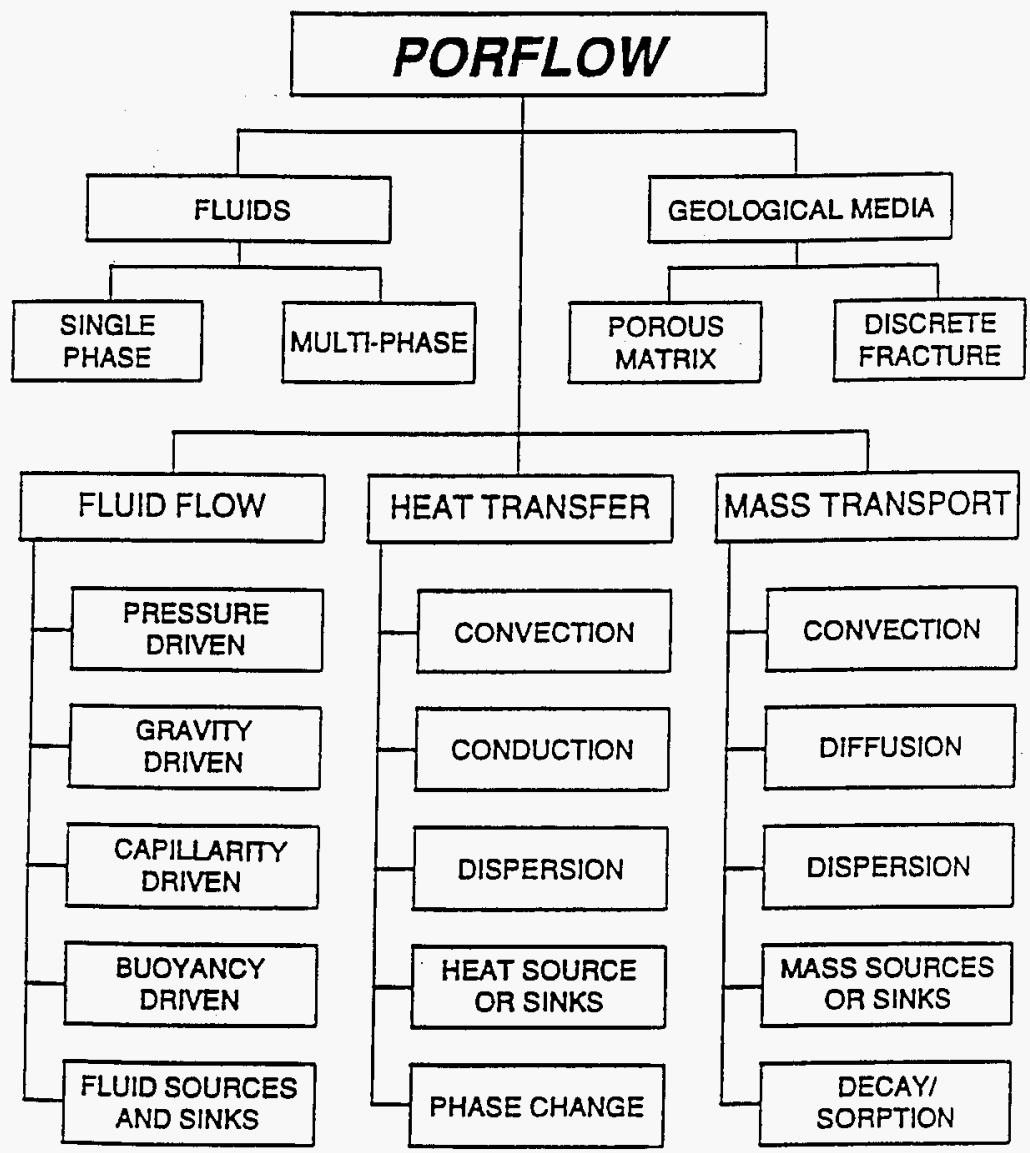




\subsection{ANALYSIS CASES}

The analysis cases were defined in terms of the six parameter groups described in Section 1.3. and a baseline case. The parameters for these cases are described in the following sections. The sensitivity cases are identified in terms of their parameter group (e.g., P1 for cases emphasizing the effects of hydrostratigraphy and hydraulic properties) and case number (e.g., P1-1 for the group P1, sensitivity case \#1 that uses hydraulic parameter values from the grout performance assessment (Piepho 1994; Kincaid et al. 1995).

\subsubsection{Baseline Case}

A baseline case (i.e., an analysis case whose premises and results are used as a point of reference for the subsequent sensitivity cases) was defined such that all sensitivity cases could easily be defined by simply identifying the change(s) to the baseline case parameters. Parameters of the baseline case, for each of the six parameter groups, are defined as follows:

- P1--Simplified stratigraphy with best-estimate values for hydrogeologic parameters

- P2--A single tank leak with a volume of 8,000 gal leaked in $0.1 \mathrm{yr}$ from a source area equal to the volume of one grid cell $(2 \mathrm{~m} \times 1.5 \mathrm{~m} \mathrm{x} 1 \mathrm{~m})$

- $\quad$ P3--No leaks that precede sluicing-water leaks

- P4--No leaks that precede sluicing-water leaks

- P5--Infiltration of meteoric water equal to $10 \mathrm{~cm} / \mathrm{yr}$ after the tank farm was constructed until $30 \mathrm{yr}$ after the initiation of sluicing; then, installation of a permanent infiltration barrier that reduces the infiltration to $0.05 \mathrm{~cm} / \mathrm{yr}$

- P6-Unit concentration with no retardation; longitudinal and transverse dispersivities of $1 \mathrm{~m}$ and $0.1 \mathrm{~m}$, respectively.

\subsubsection{Sensitivity Cases}

Three sensitivity cases were evaluated for Parameter Group P1, five for Parameter Group P2, three for Parameter Group P3, four for Parameter Group P4, three for Parameter Group P5, and none (only the baseline case) for Parameter Group P6. Hence, a total of 19 cases were simulated, including the baseline case. 
2.5.2.1 Parameter Group P1. Sensitivity cases for Parameter Group P1 focus on the affects of hydrostratigraphy and hydraulic properties of lithologic units.

Case P1-1: Use of vadose zone hydraulic data from the grout performance assessment (Piepho 1994; Kincaid et al. 1995); this data had no corrections for the effects of gravel on porosity and saturated hydraulic conductivity.

Case P1-2: Use of best-estimate (baseline case) values for hydraulic parameters, but with no corrections for the effects of gravel on porosity and saturated hydraulic conductivity.

Case PI-3: Use of a larger model domain to evaluate the effects of lateral spreading.

2.5.2.2 Parameter Group P2. This group of sensitivity analyses focused on the effects of the amount, duration, and area of leakage.

Case P2-1: Use of a leak volume equal to the average leak volume assumed for the TWRS EIS (DOE and Ecology 1996); i.e., 4,000 gal/0.1 yr.

Case P2-2: Occurrence of a large leak $(40,000 \mathrm{gal} / 0.1 \mathrm{yr})$.

Case P2-3: Occurrence of a $160,000 \mathrm{gal} / 0.4 \mathrm{yr}$ leak, distributed over the dimensions of three grid cells, rather than one grid cell. This is a reasonable "worst-case" leak for the 241-A Tank Farm complex, based on information available for the 241-A-105 Tank leak (ICF KH 1994). A leak of this magnitude is considered to have a very small probability of occurrence. Tank $241-\mathrm{AX}-101$ contains $-300,000$ gal of liquid, but at least half of that volume is not expected to drain because of the effect of capillary attraction by the sludge and salt cake particles.

Case P2-4: Occurrence of a leak distributed over an area equal to one-half of a tank circumference (depicted by nine grid cells of the model domain), rather than over the dimensions of a single grid cell.

Case P2-5: The duration of the baseline leak is $6 \mathrm{mo}$, rather than $5 \mathrm{wk}(0.1 \mathrm{yr})$.

2.5.2.3 Parameter Group P3. Sensitivity analyses of Parameter Group P3 analyzed the effects of simultaneous leakage from multiple tanks.

Case P3-1: Occurrence of simultaneous leaks from two tanks, each leaking $8,000 \mathrm{gal} / 0.1 \mathrm{yr}$ (e.g., tanks 241-AX-102, -104), with the source of each leak being equal in area to the dimension of one grid cell.

Case P3-2: Four tanks are assumed to leak simultaneously, each from an area equal to one grid-cell dimension, and each leaking $8,000 \mathrm{gal} / 0.1 \mathrm{yr}$. 
Case P3-3: Four tanks are assumed to leak simultaneously. (Equivalent to Case P2-2; i.e., 40,000 gal/0.1 yr for Tank 241-AX-101 plus leaks of 8,000 gal/0.1 yr from each of tanks 241-AX-102, -103, and -104).

2.5.2.4 Parameter Group P4. This group of sensitivity analyses focused on the cumulative effects of sluicing leaks on earlier tank leaks.

Case P4-1: Tank 241-AX-104 leaks 8,000 gal/0.1 yr beginning in 1977 and Tank 241-AX-102 leaks 3,000 gal/0.1 yr beginning in 1988. Contamination in the 8,000 -gal sluicing-related leak is assumed have 0.001 the concentration of the presluicing leak.

Case P4-1wo: Same as case P4-1, except that a sluicing leak does not occur. The objective of this case was to evaluate the behavior of a pre-existing leak in the absence of a subsequent sluicing leak. By comparing results to Case P4-1, the incremental effect of a 8,000 -gal sluicing leak on the two previous leaks in the 241-AX Tank Farm could be assessed.

Case P4-2: The characteristics of this case are as follow: Tank 241-A-105 leaks $160,000 \mathrm{gal} / 0.4 \mathrm{yr}$ beginning in 1963 from an area equal to the dimensions of three grid cells. The conceptual model used to depict the four tanks in the 241-AX Tank Farm was shifted to the 241-A Tank Farm. The 8,000-gal sluicing leak is assigned a contaminant concentration that is 0.001 that of the pre-sluicing leak.

Case P4-3: Same as Case P4-1, except that the sluicing leak has a larger volume of $40,000 \mathrm{gal}$, instead of $8,000 \mathrm{gal}$. The purpose of this case was to evaluate the effect of a large sluicing leak on prior leaks.

2.5.2.5 Parameter Group P5. These sensitivity cases focused on the impacts, as a function of time, of infiltrating meteoric water. In effect, Parameter Group P5 assessed the effects of barriers to infiltrating meteoric water on the movement of tank leaks. For purposes of the analysis, temporary barriers were assumed to be emplaced within the 30 -yr period after sluicing began. Permanent barriers were assumed to have been constructed over the 241-AX Tank Farm 30 yr after sluicing began.

Case P5-1: Infiltration of $10 \mathrm{~cm} / \mathrm{yr}$ until the end of sluicing; $0.05 \mathrm{~cm} / \mathrm{yr}$ thereafter.

Case PS-2: Infiltration of $10 \mathrm{~cm} / \mathrm{yr}$ for $10 \mathrm{yr}$ after sluicing; $0.05 \mathrm{~cm} / \mathrm{yr}$ thereafter. The objective of this case was to evaluate the effects of delaying emplacement of a temporary barrier until $10 \mathrm{yr}$ after the completion of sluicing.

Case P5-3: Infiltration of $1 \mathrm{~cm} / \mathrm{yr}$ for $30 \mathrm{yr}$ after sluicing; $0.05 \mathrm{~cm} / \mathrm{yr}$ thereafter. This case depicts installation of a temporary infiltration barrier that is only $90 \%$ 
effective (i.e., reduces the infiltration rate from $10 \mathrm{~cm} / \mathrm{yr}$ to $1 \mathrm{~cm} / \mathrm{yr}$ ). The objective of this case was to assess the potential benefit of installing a relatively low-cost, temporary infiltration barrier that permits continued access to the tanks.

2.5.2.6 Parameter Group P6. No sensitivity cases were defined for the geochemical/ inventory parameter group because unit concentrations were used for contamination from the pre-sluicing leak. The generic contaminant species was assumed to be mobile (i.e., a distribution coefficient of zero was used) and have no radioactive decay. The dispersion parameters were also fixed at reasonable minimum values.

2.5.2.7 Considerations for Additional Analyses. Additional sensitivity analyses merit future consideration. Recommendations in that regard include evaluation of a case with larger dispersion coefficients and a case with a different location of the leak relative to the geometry of the tank (e.g., a leak other than at the periphery of a tank). When flow-property values specific to vadose zone lithologies beneath the 241-AX Tank Farm become available (Barnett et al. 1996), a detailed update of the stratigraphic description provided in Appendix A should be used to revisit the sensitivity analyses for Parameter Group P1. 


\subsection{RESULTS OF ANALYSIS}

Results for the sensitivity cases are described and graphically depicted as plots of fractional release versus time for each sensitivity case. The fractional release curve portrays the fraction of contaminant mass in a sluicing leak or pre-sluicing leak predicted to reach the water table in a specified time. In addition, a plot of concentration contours is shown for some sensitivity cases at various times after the sluicing leak hypothetically occurs.

\subsection{PARAMETER GROUP P1}

Results for this parameter group analyze effects on the performance measures of hydraulic data, stratigraphy, and model domain size.

\subsubsection{Contaminant Releases to the Water Table for P1 Cases}

The fractional release curves for this group are shown in Figure 3-1. The baseline case, which consisted of an 8,000-gal leak occurring over a 5-wk period, shows that about $26 \%$ of the contaminant mass will reach the water table $\sim 1,000$ yr after the sluicing leak begins. Small amounts of the contaminant reach the water table $\sim 80 \mathrm{yr}$ after the leak begins.

Results for Case P1-3 (larger model domain) show that the larger model domain has no significant effect on the vertical flux of contaminants to the water table. As confirmed by the results for Parameter Group P6, the larger model domain allows the contaminant to become distributed over a larger area in the vadose zone. However, the broader distribution results in lower concentrations entering the water table over a larger area, such that the total contaminant flux to the water table is the same as that for the baseline case.

Results for Case P1-1, which used the grout performance assessment (Piepho 1994; Kincaid et al, , 1995) hydraulic data, show a large increase in contaminant reaching the water table by a specified time compared to the baseline case. For Case P1-1, 54\% of the contaminant mass reached the water table by $\sim 1,000$ yr after the sluicing leak began; small amounts of the contaminant reach the water table $\sim 60 \mathrm{yr}$ after the sluicing leak began.

The results from Case P1-1 demonstrate the importance of detailed, site-specific hydraulic properties data to the credibility of contaminant transport predictions used to help resolve issues of relative risk and regulatory compliance. In Case P1-1, the use of data from the grout performance assessment for the 241-AX Tank Farm resulted in a two-fold increase in the amount of contaminant predicted to reach the water table in $1,000 \mathrm{yr}$, and a much larger increase for durations of $<1,000 \mathrm{yr}$. Because many accepted measures of relative risk are directly proportional to the mass of contaminant reaching a receptor per unit of time, reduction of unacceptable uncertainty in assessing these risks requires the use of verifiable, site-specific hydraulic properties data. 
WHC-SD-WM-ANAL-052, Rev. 0

Figure 3-1. Fractional Release Curves for Parameter Group P1 Cases.

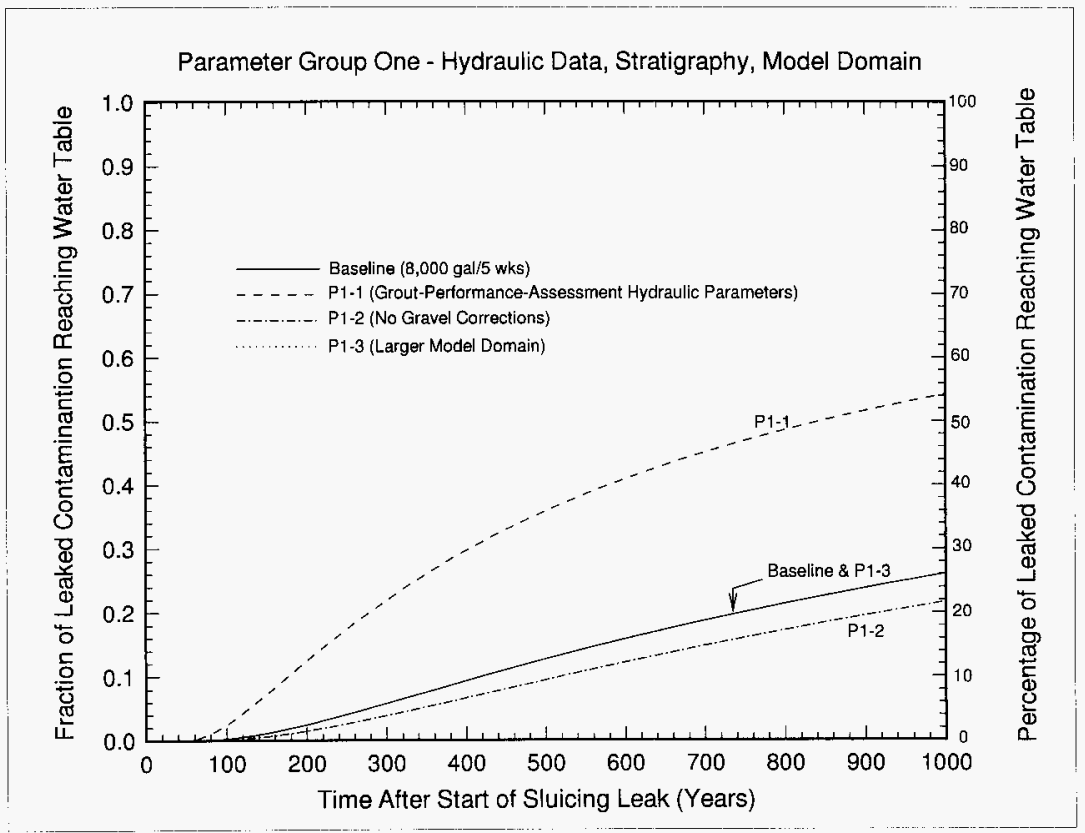


Results from Case P1-1 also were compared to results from Case P1-2. This comparison was made because grout project analyses did not use hydraulic data adjusted to account for gravel in the stratigraphic column. Both Case P1-2 and the baseline case used hydraulic data corrected for the presence of gravel. The gravel corrections for the baseline case are described in detail in Appendix B.

Hydraulic properties data require adjustment when gravel is present in the stratigraphic column because gravel particles have essentially no effective porosity. Hence, the presence of gravel effectively reduces the cross-sectional area through which flow can occur. Other factors being equal, the occurrence of gravel results in more rapid movement of leaks from SSTs through the vadose zone because flow is channeled through an effectively reduced cross sectional area.

Based on currently available stratigraphic information, lithologic units beneath the 241-AX Tank Farm may contain relatively little gravel. Consequently, the results for Case P1-2, without the gravel corrections, show only a modest decrease in the mass flux of contaminants reaching the water table in a specified duration. A relatively large difference would result from the use of gravel-corrected hydraulic data versus uncorrected data where tank farms are underlain by comparatively gravelly sediments.

The maximum gravel content of sediments underlying the 241-AX Tank Farm has been estimated based on relatively near-surface information to be about $30 \mathrm{wt} \%$ (see Appendix A). In contrast, sediments that underlie other tank farms locally consist of $>50 \mathrm{wt} \%$ gravel. Furthermore, open-framework gravel, in which gravel particles are supported by other gravel particles with little or no intervening finer-grained silt or sand, is common at the Hanford Site. The presence of open-framework gravel would facilitate very rapid transport of leaked contaminants to the water table and, concomitantly, result in very little retention of the leaked contaminants in the vadose zone.

\subsubsection{Contaminant Concentration Contours for Baseline Case and Case P1-3}

Contaminant concentration contours for the baseline case are shown in Figure 3-2. The concentration contours for Case P1-3, using the expanded model domain, are shown in Figure 3-3. The distribution of contours for Case P1-3 clearly indicates a marginally larger spread of contaminants than for the baseline case, for $30 \mathrm{yr}$ after a sluicing leak begins. There are lower concentrations in the vadose zone of the expanded model domain because the contaminant plume can spread out more over the larger domain. However, the contaminant flux to the water table is not smaller (see Figure 3-1) for the expanded model domain, even though it has lower concentrations. This is because the lower concentrations are spread out over a larger area above the water table, and the mass flux is a product of concentration (just above water table), area, and infiltration rate. Hence, the lower concentrations times the larger area for the expanded model domain is the same as the larger concentrations times a smaller area for the baseline case (see Figure 3-1). 
WHC-SD-WM-ANAL-052, Rev, 0

Figure 3-2. Concentration Contours for Baseline Case 30 Yrs after Sluicing.

Simulated Relative Concentration of Mobile Contaminant 30 Yr After Sluicing Leak; 8,000-Gal Leak; Duration of 5 Wks

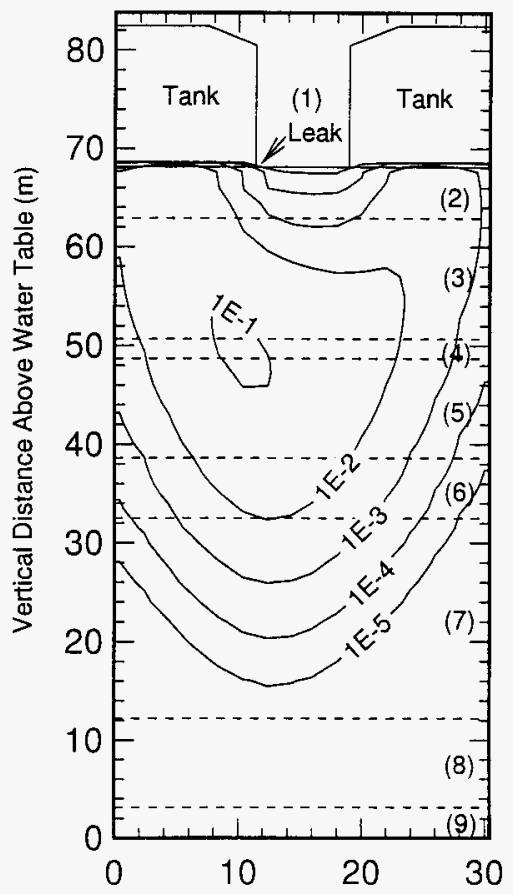

Horizontal Distance From Center of Tank at Left (m) 
WHC-SD-WM-ANAL-052, Rev. 0

Figure 3-3. Concentration Contours for Case P1-3 (Larger Model Domain).

\section{Simulated Relative Concentration of Mobile Contaminant}

30 Yr After Sluicing Leak; 8,000-Gal Leak; Duration of 5 Wks

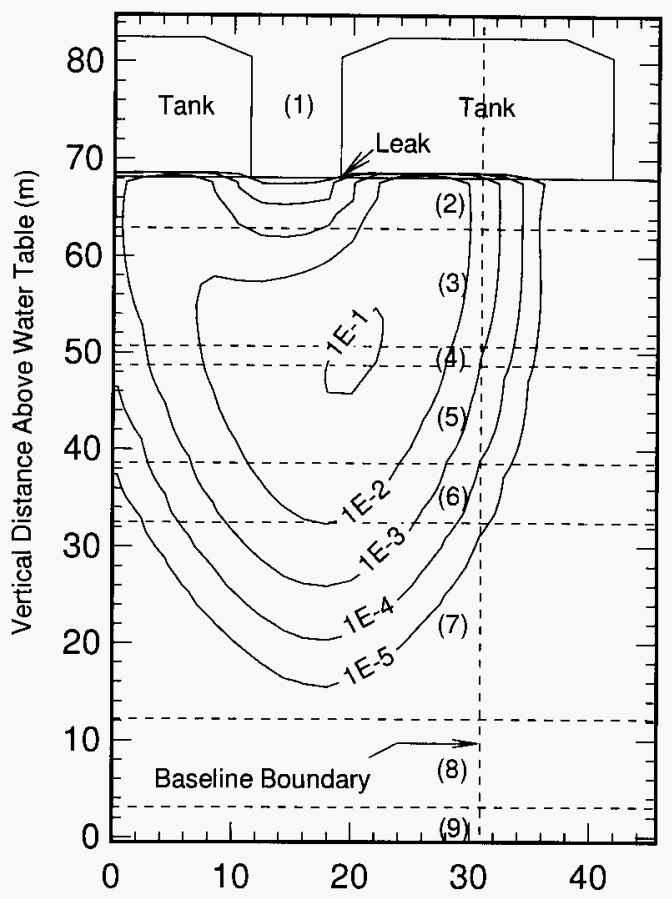

Horizontal Distance From Center of Tank at Left (m) 
Figure 3-4 shows the concentration contours for the baseline case 1 yr after sluicing ends. Comparison of this figure with Figures 3-2 and 3-3 shows how rapidly the contaminants spread under the tanks. The rapid spread of the contaminant plume has important implications on the potential cost of mitigation as a function of time.

\subsection{PARAMETER GROUP P2}

Parameter Group P2 consists of the parameters affecting the volume and duration of the sluicing leak, and areal extent of the leak source.

\subsubsection{Contaminant Releases to the Water Table for P2 Cases}

Curves that depict the fraction of leaked contaminant entering the water table as a function of time for Parameter Group P2 sensitivity cases are shown in Figure 3-5. Leaks for all sensitivity cases were given the same unit concentration of contaminant.

For example, Case P2-3 has a leak volume of $160,000 \mathrm{gal}$, which is $\sim 20$ times that of the baseline leak volume of 8,000 gal. Hence, in Case P2-3 there is 20 times more contaminant mass leaked than in the baseline case. The total mass of contaminant reaching the water table compared to the baseline case is shown in Figure 3-6.

The results clearly show that, disproportionately to the leak size, a larger fraction of the large-leak contaminants enter the aquifer by a specified time. For example, 1,000 yr after the sluicing leak begins, results for Case P2-3 show that $\sim 53 \%$ of the contaminant mass (the mass of which is 20 times larger than that of the baseline case) has entered the aquifer compared to only $26 \%$ of the contaminant mass leaked for the baseline case. The implication of this is that, for an equal volume of leaked contaminant entering the water table, a 160,000 gal leak is likely to have twice the impact on groundwater quality as an 8,000 gal leak after $1,000 \mathrm{yr}$. The impact is even larger for times $<1,000 \mathrm{yr}$. In other words, the rate at which the two mass-flux curves diverge from one another is larger at earlier times, as shown in Figures 3-5 and 3-6.

Results for Case P2-4, in which the sluicing leak occurs from an area equal to a halftank circumference rather than a single grid cell, indicate that a smaller fraction of contaminant is released to the water table than for the baseline case. This result reflects that the leak has been distributed over a larger area, resulting in a lower moisture content within that area. Hence, the contaminant moves less rapidly because the moisture-holding capability (i.e., matric potential) of relatively dry sediments is more effective than that of relatively wet sediments in holding the moisture.

Results for Case P2-5, in which the duration of the sluicing leak is 6 mo rather than 5 wk, is also shown in Figure 3-5. A longer leak duration generally does not affect the contaminant flux to the aquifer if the leak volumes are equal. After the passage of $\geq 100 \mathrm{yr}$, the duration of the leak is not important in determining the contaminant flux to the water table. 
Figure 3-4. Concentration Contours for Baseline Case $1 \mathrm{yr}$ after Sluicing.

Simulated Relative Concentration of Mobile Contaminant One Yr After Sluicing Leak; 8,000-Gal Leak; Duration of 5 Wks

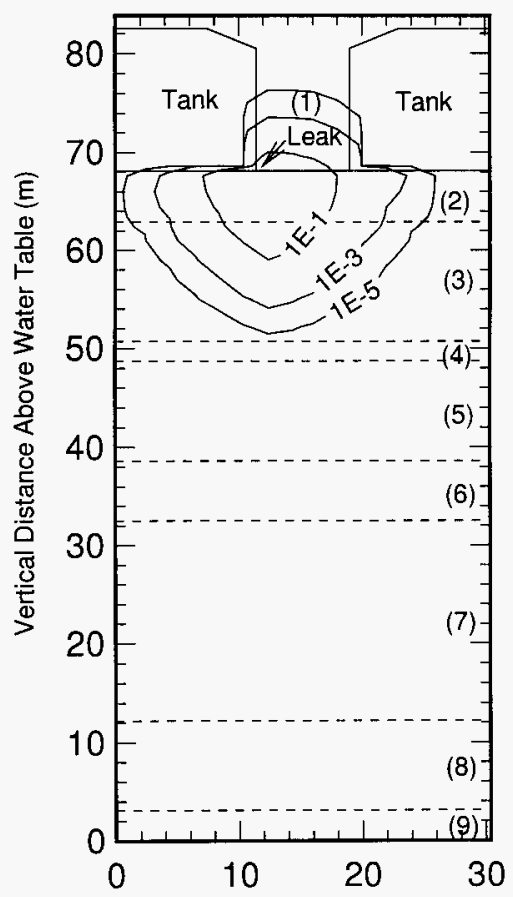

Horizontal Distance From Center of Tank at Left (m) 
WHC-SD-WM-ANAL-052, Rev. 0

Figure 3-5. Fractional Release Curves for Parameter Group P2 Cases.

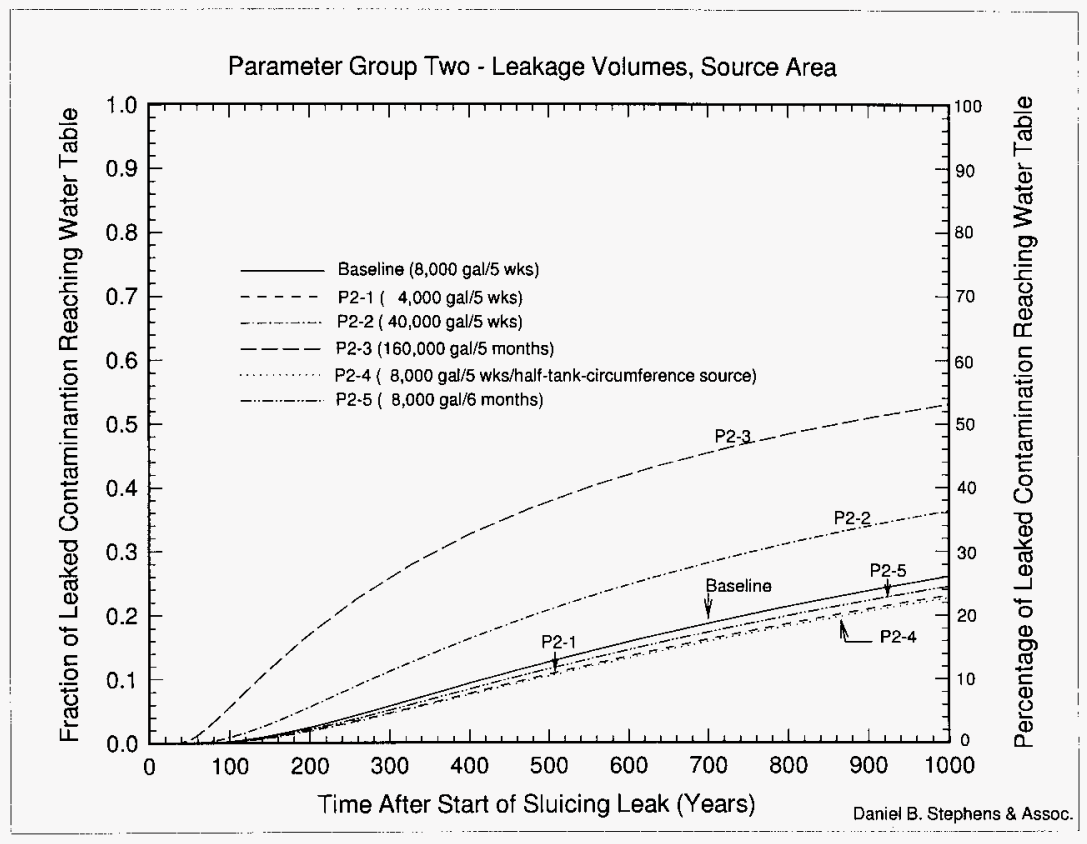


WHC-SD-WM-ANAL-052, Rev. 0

Figure 3-6. Total Mass Release Curves for Parameter Group P2 Cases.

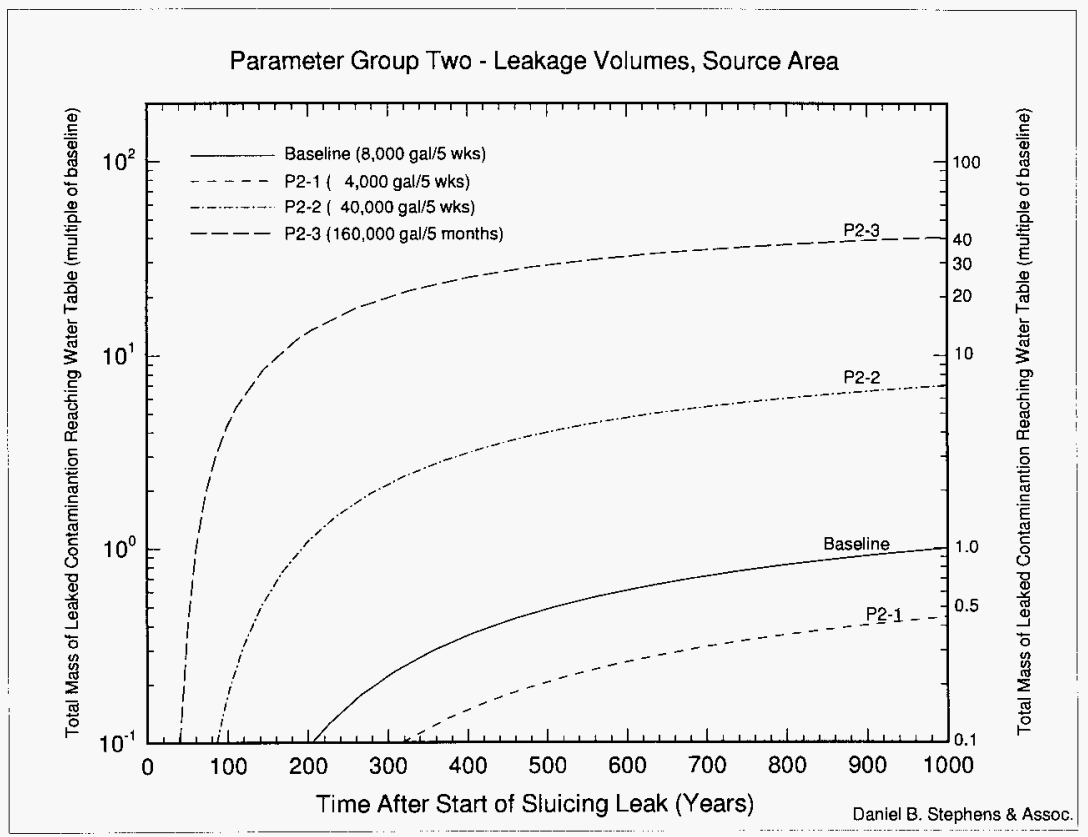


In general, if the leak duration is significantly shorter than the travel time through the vadose zone, then the contaminant flux rate to the water table is not sensitive to the duration of the leak.

\subsubsection{Contaminant Concentration Contours for Case P2-3 (Largest Leak)}

Concentration contours for the large (160,000-gal) sluicing leak $1 \mathrm{yr}$ after the leak occurs are shown in Figure 3-7. Results shown in the figure suggest that the contaminants have migrated much deeper under the tanks than for the smaller baseline-case leak (see Figure 3-4). The large leak has penetrated about $40 \mathrm{~m}$ below the tanks; the smaller baseline leak penetrated about $15 \mathrm{~m}$. Clearly, the volume of a very large leak enhances the transport of contaminants contained in the leak to the water table.

\subsection{PARAMETER GROUP P3}

Parameter Group P3 consists of parameters used to evaluate the effects of simultaneous leaks. Sensitivities to the number of such leaks and their volumes were evaluated. The results of multi-leak simulations are of interest in indicating whether the deleterious effects on groundwater quality of singular leaks would likely be amplified by simultaneous leakage of several adjacent tanks being sluiced at the same time. In other words, if multiple leaks produce a fractional release curve that is more steeply sloped than the corresponding curve for a single leak, then it may be ill advised to simultaneously sluice waste from several tanks in the same tank farm at the same time.

\subsubsection{Contaminant Releases to the Water Table for P3 Cases}

The fractional release curves for Parameter Group P3 sensitivity cases are shown in Figure 3-8. The fractional release rates are about the same for two to four leaks, each with a leak volume of 8,000 gal. Although multiple leaks will release more contaminant mass than a single leak, as shown in Figure 3-9, the fractional release rates to the water table are about the same as for single leaks.

If the volume of one of the leaks is 40,000 gal, then the fractional release rate is somewhat amplified, as shown by the results for Case P3-3. This case had three 8,000-gal leaks and one 40,000-gal leak.

In summary, results from these cases show that simultaneous sluicing of waste from several tanks in the same tank farm will not significantly increase the impacts on groundwater quality compared to multiple leaks occurring at different times. 
WHC-SD-WM-ANAL-052, Rev. 0

Figure 3-7. Contaminant Concentration Contours for Case P2-3 (Largest Leak).

Simulated Relative Concentration of Mobile Contaminant

One Yr After Sluicing Leak; 160,000-Gal Leak; Duration of 5 Months

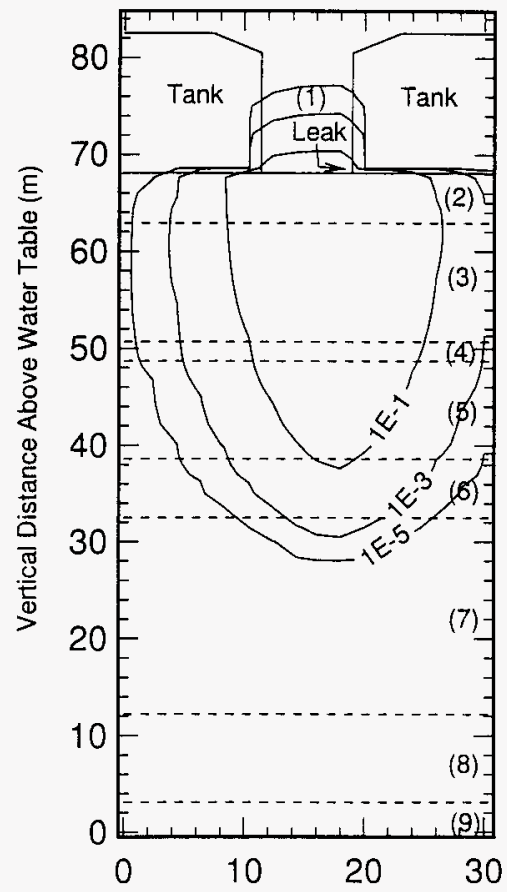

Horizontal Distance From Center of Tank at Left ( $m$ ) 
WHC-SD-WM-ANAL-052, Rev. 0

Figure 3-8. Fractional Release Curves for Parameter Group P3 Cases.

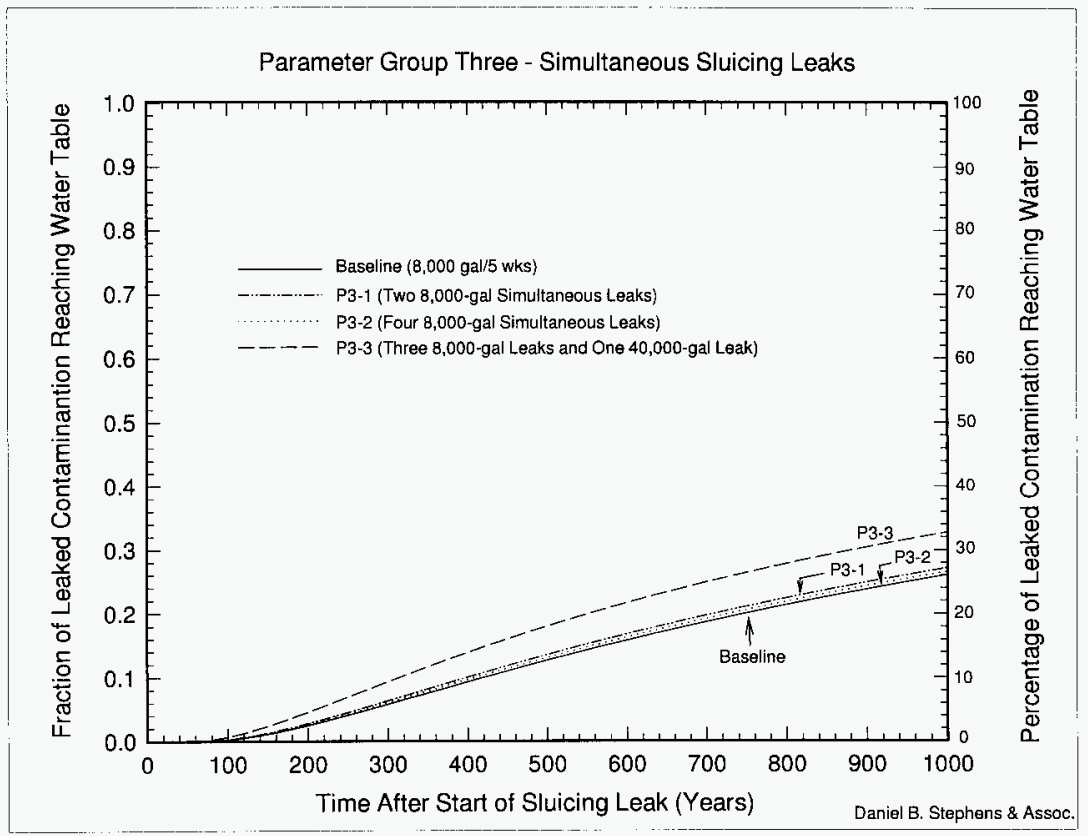


WHC-SD-WM-ANAL-052, Rev. 0

Figure 3-9. Total Mass Release Curves for Parameter Group P3 Cases.

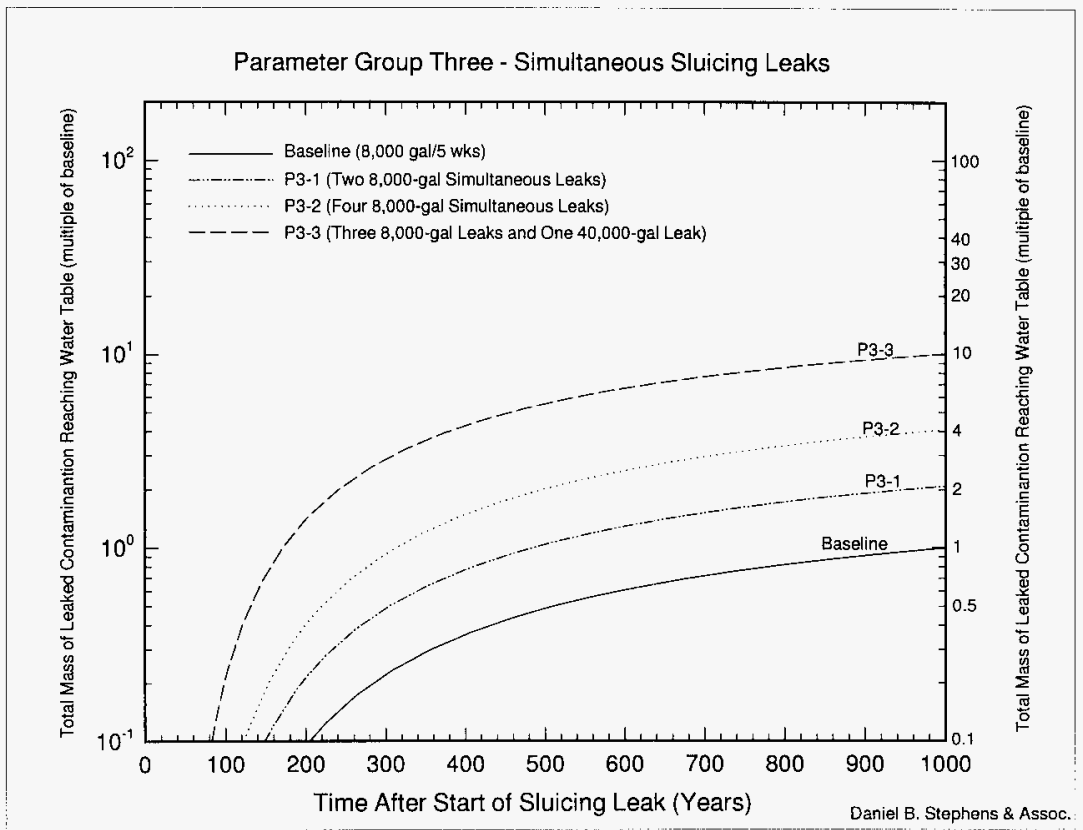




\subsubsection{Contaminant Concentration Contours for Case P3-1 (Multiple Leaks)}

Results for Case P3-1 are shown as concentration contours in Figure 3-10. The results for Case P3-1 clearly show that there is an increase in contaminant concentration relative to the baseline case because more contaminant mass is present (see Figure 3-9). However, the fractional mass release rate to the water table is about the same as for the baseline case (see Figure 3-8), indicating that the two simultaneous leaks of Case P3-1 are sufficiently far apart to behave the same as two leaks occurring at different times. The results indicate that the volume of precipitation infiltrating from the surface is sufficient to dominate the vadose zone transport of the contamination to the water table for both the baseline case and multiple-leak cases P3-1 and P3-2).

\subsection{PARAMETER GROUP P4}

Parameter Group P4 consists of parameters that depict past leaks in the 241-AX Tank Farm and the largest leak in the 241-A Tank Farm. These leaks pre-date the sluicing leaks simulated for the 241-AX Tank Farm. The objective of these cases was to indicate what effect sluicing leaks would have on the pre-sluicing leaks.

A unit concentration was assumed for contaminants from past leaks. A much smaller concentration $(0.001)$ was assumed for contaminants leaked during subsequent sluicing. This ratio was used to focus the analysis on the effect of sluicing on the contaminant mass in the pre-sluicing leak and is based on the assumption that the addition of clean sluicing water to SSTs typically will significantly dilute the concentrations of mobile contaminants in the waste.

\subsubsection{Contaminant Releases to the Water Table for P4 Cases}

Results for Parameter Group P4 are expressed as fractional release curves in Figure 3-11. Case P4-1 simulated the two pre-existing leaks in the 241-AX Tank Farm. Tank 241-AX-104 leaked 8,000 gal in 1977. Tank 241-AX-102 leaked 3,000 gal in 1988 (ICF KH 1994). Case P4-1wo is the same as Case P4-1, but without a sluicing leak.

The curves for these two cases clearly show that an 8,000-gal sluicing leak would have little effect on the pre-sluicing leaks in the 241-AX Tank Farm. This conclusion is attributed to the fact that $30 \mathrm{yr}$ of precipitation infiltrating at a rate of $10 \mathrm{~cm} / \mathrm{yr}$ (which for the modeling domain is equal to $-24,000 \mathrm{gal} / \mathrm{yr}$ ) dominates whatever effect is attributable to the much smaller 8,000 -gal sluicing leak. A larger sluicing leak would have a much larger impact, as indicated by Case P4-3.

\subsubsection{Contaminal Concentration Contours for P4 Cases}

To keep the number of illustrations at a manageable number showing information critical to the conclusion, contaminant concentration contours are not shown for Parameter Group P4 cases. 
WHC-SD-WM-ANAL-052, Rev. 0

Figure 3-10. Contaminant Concentration Contours for Case P3-1 (Multiple Leaks).

Simulated Relative Concentration of Mobile Contaminant 30 Yr After Sluicing Leak; Two 8,000-Gal Leaks; Duration of 5 Wks

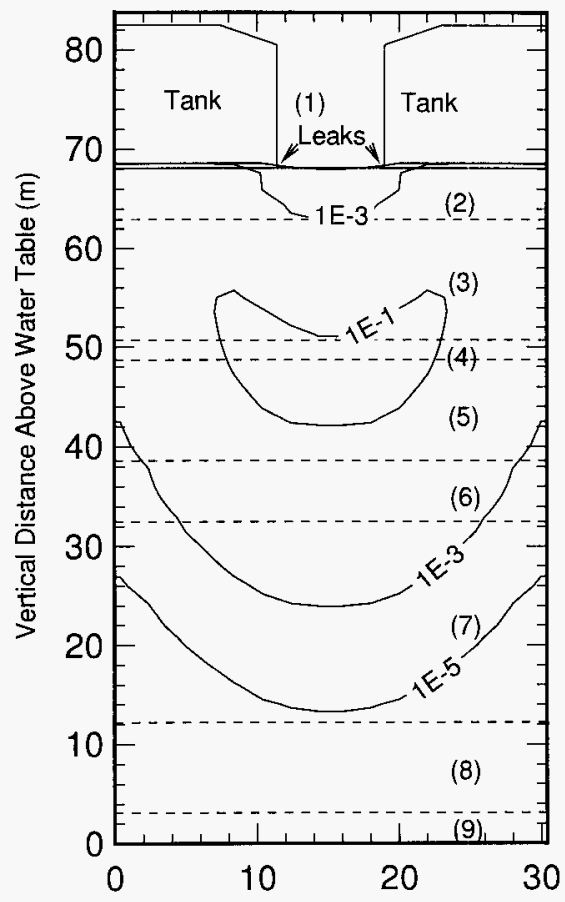

Horizontal Distance From Left Tank Center $(\mathrm{m})$ 
WHC-SD-WM-ANAL-052, Rev. 0

Figure 3-11. Fractional Release Curves for Parameter Group P4 Cases.

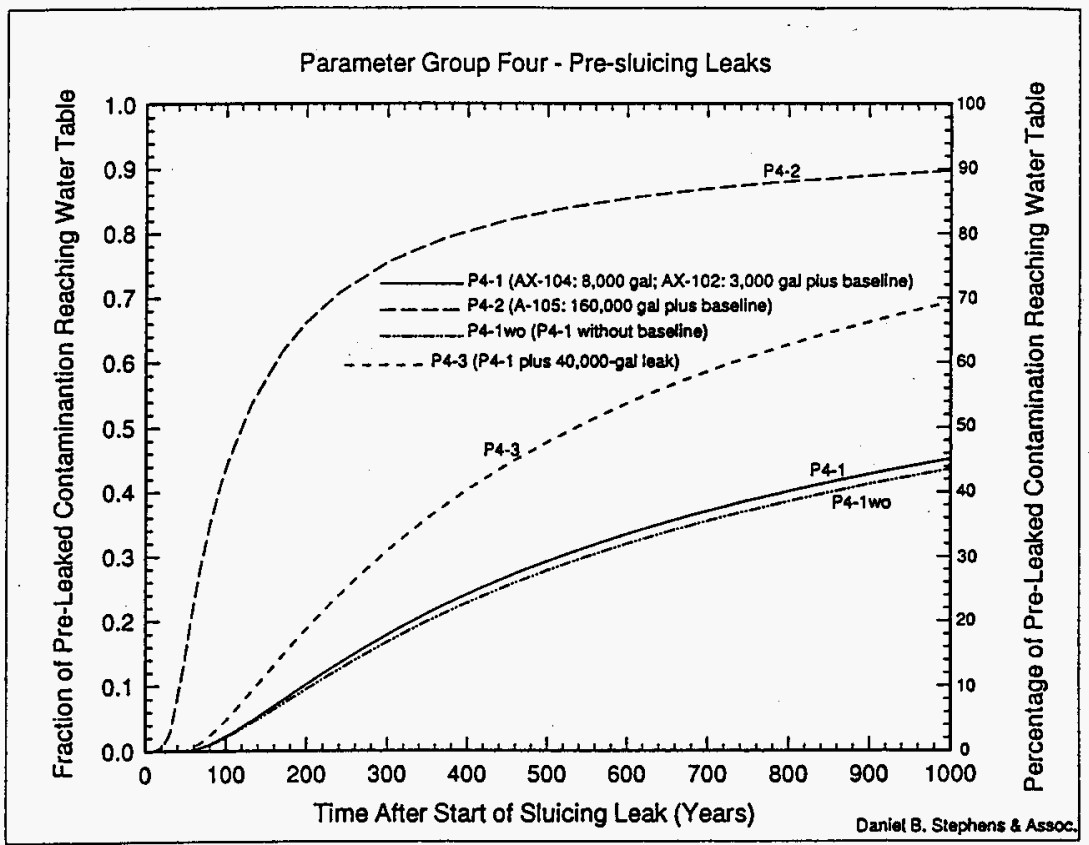


Case P4-2 evaluated the effects of a large leak from Tank 241-A-105 that predates sluicing. Based on available information, this tank was assumed to have leaked 160,000 gal in 1963. The actual volume leaked is not known but could range from 10,000 gal to 277,000 gal (Hanlon 1994). Results for this case indicate that the contaminant mass from this leak would reach the water table within the next $20 \mathrm{yr}$.

Case P4-3 evaluates the effects of a larger sluicing leak on pre-sluicing leaks in the 241-AX Tank Farm. In other words, this case is identical to Case P4-1 except that a 40,000 -gal sluicing leak is simulated instead of an 8,000-gal sluicing leak. The larger leak significantly enhances transport of contaminants in the pre-sluicing leak, as shown by the fractional release curve for Case P4-3 in Figure 3-11.

\subsection{PARAMETER GROUP P5}

Parameter Group P5 consists of parameters relating to effects of the time of emplacement of an infiltration barrier and the effects of partial leakage of precipitation through that barrier. The sensitivity cases evaluate the effects of emplacing permanent or temporary barriers at various times. The objective of these sensitivity cases was to evaluate the potential effectiveness of a temporary infiltration barrier emplaced (1) immediately after the end of sluicing and (2) $10 \mathrm{yr}$ after the end of sluicing.

The baseline case assumed that no barrier was constructed until $30 \mathrm{yr}$ after sluicing. Hence, for $30 \mathrm{yr}$, about $\sim 24,000$ gal of meteoric water per year were assumed to enter the top of the modeling domain (a surface area of $10,000 \mathrm{ft}^{2}$ ).

\subsubsection{Contaminant Releases to the Water Table for P5 Cases}

The fractional release curves for Parameter Group P5 are shown in Figure 3-12. Because of the low flux rates, the plot is shown on a log scale. Case P5-1, which has the lowest flux rate, assumed that an infiltration barrier is constructed over the 241-AX Tank Farm immediately after sluicing is completed. Infiltration through the temporary barrier was assumed to be $0.05 \mathrm{~cm} / \mathrm{yr}$. For this case, the fraction of the leaked contaminant mass predicted to reach the aquifer in $1,000 \mathrm{yr}$ is $<1 \%$. Hence, the results clearly indicate the beneficial effect that would result from expedited construction of a temporary barrier.

If a temporary barrier to the infiltration of precipitation were emplaced $10 \mathrm{yr}$ after the end of sluicing (Case P5-2), the fractional release curve again shows that the flux of contaminants to the water table is much smaller at any specified time than it is for the corresponding baseline case. Case P5-3 assumes that the temporary barrier allows $1 \mathrm{~cm} / \mathrm{yr}$ infiltration through the top of the model domain, rather than the $0.05 \mathrm{~cm} / \mathrm{yr}$ allowed by a permanent barrier with significantly better performance, as which was assumed for cases P5-1 and P5-2. Even if the temporary barrier is only $90 \%$ effective, the fractional release curve is 
WHC-SD-WM-ANAL-052, Rev. 0

Figure 3-12. Fractional Release Curves for Parameter Group P5 Cases.

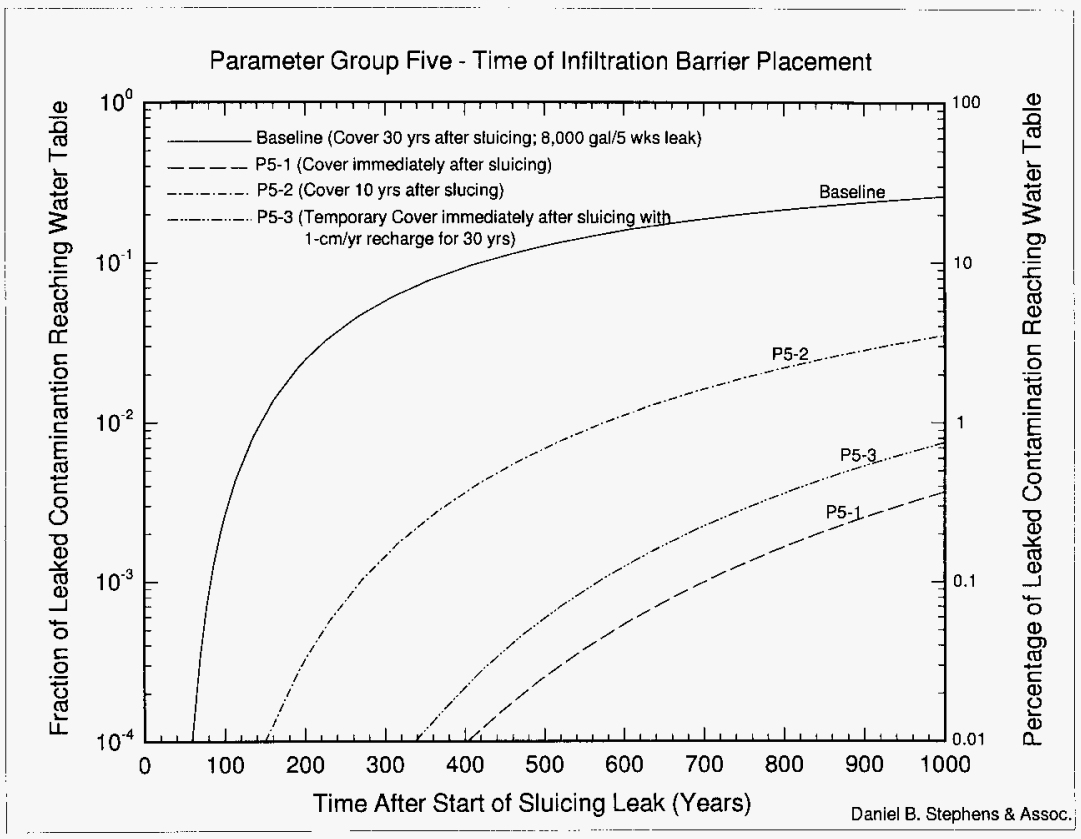


much smaller than that for the baseline case. For Case P5-3, the fraction of contaminant mass reaching the water table is $<1 \%$ after $1,000 \mathrm{yr}$.

Results from these cases show that emplacement of a temporary barrier to infiltrating precipitation could be very effective in slowing the release of contaminants to the water table. A temporary barrier presumably could be emplaced over a tank farm much sooner than a permanent barrier. Construction of the latter would likely require regulatory approval for tank farm closure. That, in turn, may require a lengthy period of time to remove residual waste and backfill the tanks with an inert material needed to structurally support the weight of a permanent barrier.

\subsubsection{Contaminant Concentration Contours for P5 Cases}

To keep the number of illustrations at a manageable number showing information critical to the conclusions, contaminant concentration contours are not shown for Parameter Group P5 cases. 
WHC-SD-WM-ANAL-052, Rev. 0

\subsection{CONCLUSIONS, SUMMARY AND RECOMMENDATIONS}

Evaluation of the results of the sensitivity analyses lead to several significant conclusions. Those conclusions and several recommendations based on them are summarized in the following sections.

\subsection{CONCLUSIONS}

The predicted durations after sluicing for various percentages of contaminant mass in sluicing leaks to reach the water table are shown in Table 4-1. The table shows travel times for $0.1 \%, 1 \%$, and $10 \%$ of the mobile contaminant mass in the hypothetical sluicing leaks to reach the water table. Each case simulated is ranked with respect to the time required for $0.1 \%$ of the contaminant mass to reach the water table.

The shortest times for $0.1 \%$ of the contaminant mass in the leak to reach the water table are associated with the largest leak. The pre-sluicing leak of 160,000 gal is predicted to reach the water table within $10 \mathrm{yr}$ after a subsequent sluicing leak. A sluicing leak of 8,000 gal appears to be relatively insignificant because its effects are overwhelmed by the comparatively large volume of water from natural precipitation that annually enters the top of the model domain and eventually enters the water table $(\sim 24,000 \mathrm{gal} / \mathrm{yr})$.

The pre-sluicing leak of $11,000 \mathrm{gal}$ in the 241-AX Tank Farm is the next leak to reach the water table, with or without a subsequent sluicing leak. However, if the volume of the sluicing leak is $40,000 \mathrm{gal}$, then the pre-sluicing leak reaches the aquifer in less time. Cases P4-1 and P4-1wo show that an 8,000-gal sluicing leak has no significant effect on the time required for a pre-existing leak to reach the water table.

A 40,000-gal sluicing leak is the next leak to reach the water table; the leak for the case using hydraulic data from the grout performance assessment follows close behind. Results for the case using grout performance assessment data demonstrate the importance of using good quality, site-specific hydraulic data. The travel times for this case are nearly the same as those for the case with the 40,000 -gal leak, even though the grout-data case had only an 8,000-gal leak. In fact, the grout-data case had shorter travel times than the 40,000 -gal leak case (P2-2), for $1 \%$ and $10 \%$ of the contaminant mass to reach the water table and these travel times were as short as those for cases with pre-sluicing leaks.

The simultaneous-leak cases have the next shortest travel times. The case in which one of the leaks is 40,000 gal has the fastest travel time of the group. The P3-1 and P3-2 simultaneous-leak cases, which have only 8,000-gal sluicing leaks, have travel times approximating those of the baseline case which had only a single leak. Hence, these cases show that travel times are not appreciably enhanced if simultaneous leaks occur. 
Table 4-1. Time After Sluicing Leak for Contaminant to Reach the Water Table.

\begin{tabular}{|c|c|c|c|c|}
\hline Case & Description & $\begin{array}{c}\text { Time for } 0.1 \% \text { to } \\
\text { Reach Water Table (yr) }\end{array}$ & $\begin{array}{l}\text { Time for } 1 \% \text { to } \\
\text { Reach Water Table (yr) }\end{array}$ & $\begin{array}{c}\text { Time for } 10 \% \text { to Reach } \\
\text { Water Table }(y r)\end{array}$ \\
\hline P4-2 & $\begin{array}{c}\text { Pre-sluicing leak } \\
(160,000 \mathrm{gal})\end{array}$ & 10 & 21 & 40 \\
\hline $\mathbf{P} 2-3$ & $\begin{array}{l}160,000 \text {-gal } \\
\text { sluicing leak }\end{array}$ & 40 & 59 & 139 \\
\hline P4-3 & $\begin{array}{l}\text { Pre-sluicing leaks ( } 11,000 \mathrm{gal}) \\
\text { with } 40,000 \text {-gal sluicing leak }\end{array}$ & 46 & 64 & 142 \\
\hline P4-1 & $\begin{array}{l}\text { Pre-sluicing leaks } \\
\quad(11,000 \mathrm{gal})\end{array}$ & 53 & 80 & 200 \\
\hline P4-1wo & $\begin{array}{l}\text { Pre-sluicing leaks, but no } \\
\text { sluicing leak }\end{array}$ & 53 & 81 & 208 \\
\hline P2-2 & 40,000-gal sluicing leak & 62 & 100 & 280 \\
\hline $\mathrm{P} 1-1$ & $\begin{array}{l}\text { Grout performance assessment } \\
\text { hydraulic data }\end{array}$ & 65 & 80 & 180 \\
\hline P3-3 & $\begin{array}{l}4 \text { simultaneous leaks } \\
\text { with one } 40,000 \mathrm{gal}\end{array}$ & 66 & 110 & 315 \\
\hline P3-1 & $\begin{array}{l}2 \text { simultaneous sluicing leaks } \\
(8,000 \text { gal each })\end{array}$ & 80 & 139 & 400 \\
\hline P3-2 & $\begin{array}{l}4 \text { simultaneous sluicing leaks } \\
(8,000 \mathrm{gal} \text { each })\end{array}$ & 80 & 140 & 411 \\
\hline Pl-3 & $\begin{array}{l}50 \% \text { larger } \\
\text { model domain }\end{array}$ & 80 & 140 & 422 \\
\hline Baseline & $\begin{array}{l}8,000-\text { gal sluicing leak for } \\
5 \mathrm{wk}\end{array}$ & 80 & 140 & 422 \\
\hline P2-5 & $\begin{array}{l}8,000 \text {-gal sluicing leak for } \\
6 \mathrm{mo}\end{array}$ & 84 & 152 & 450 \\
\hline $\mathrm{P} 2-1$ & 4,000 -gal sluicing leak & 88 & 159 & 479 \\
\hline P2-4 & $\begin{array}{l}\text { Half-tank circumference } \\
\text { sluicing leak }\end{array}$ & 88 & 160 & 483 \\
\hline P1-2 & $\begin{array}{c}\text { No gravel correction of } \\
\text { hydraulic data }\end{array}$ & 98 & 170 & 520 \\
\hline P5-2 & $\begin{array}{c}\text { Permanent cover } 10 \text { yr after } \\
\text { leak }\end{array}$ & 270 & 574 & $>1000$ \\
\hline P5-3 & $\begin{array}{c}\text { Temporary cover immediately } \\
\text { after leak }\end{array}$ & 570 & $>1000$ & $>1000$ \\
\hline P5-1 & $\begin{array}{l}\text { Permanent cover immediately } \\
\text { after leak }\end{array}$ & 700 & $>1000$ & $>1000$ \\
\hline
\end{tabular}


If a sluicing leak occurs during a 6-mo rather than a $5 \mathrm{wk}$ period, then the travel times are slightly ( $4 \mathrm{yr}$ or $5 \%$ ) slower. A smaller sluicing leak of 4,000 gal also has slightly ( $8 \mathrm{yr}$ or $10 \%)$ slower travel times than the baseline case. The reason that these travel times are not longer is that the meteoric water infiltrating into the top of the model domain $(\sim 24,000 \mathrm{gal} / \mathrm{yr})$, not the leak itself, drives the contents of any small leak to the water table. If $8,000 \mathrm{gal}$ of sluicing water leaks from half of the tank perimeter, then the travel time (for $0.1 \%$ of mass) is about $10 \%$ longer than for the same-sized leak in the base case from a point source. Case P1-2 shows that the gravel corrections of the hydraulic data are important and should not be overlooked in simulating groundwater flow and contaminant transport.

The slowest travel times by far are for cases that include emplacement of an infiltration cover before $30 \mathrm{yr}$ elapse after sluicing. Even if the infiltration cover is only $90 \%$ efficient and allows water to infiltrate at the rate of $1 \mathrm{~cm} / \mathrm{yr}$, the travel times are much longer than for cases in which no infiltration barrier is present. From the perspective of the performance measures, installation of a temporary barrier over the 241-AX Tank Farm immediately after sluicing is indicated to be preferable to placing a permanent cover over the tank farm $10 \mathrm{yr}$ after sluicing.

This conclusion is reached because a temporary barrier could be expected to allow only $30 \mathrm{~cm}$ of infiltration from precipitation during $30 \mathrm{yr}$, whereas a permanent barrier emplaced $10 \mathrm{yr}$ after sluicing is predicted to allow $\sim 100 \mathrm{~cm}$ of water to infiltrate during the same $30 \mathrm{yr}$. Hence, expeditious emplacement of an infiltration barrier is indicated because, in the absence of a barrier, each year $\sim 24,000 \mathrm{gal}$ of meteoric water can be expected to infiltrate a $100 \mathrm{ft} \mathrm{x}$ $100 \mathrm{ft}$ surface area in the 200 Area tank farms.

The percentage of contaminant mass in a pre-sluicing or sluicing leak that reaches the water table within a specific time after the sluicing leak ends is also of interest. These results are shown for all cases in Table 4-2. Each result for 1,000 yr after sluicing is listed in order of largest to smallest percentage of contaminant mass reaching the water table.

The conclusions from Table 4-2 are essentially the same as those from Table 4-1 and discussed above. However, the grout-data case is ranked higher in Table 4-2 than in Table 41 , emphasizing the importance of reliable site-specific hydraulic data. A larger percentage of contaminant mass reaches the groundwater in $1,000 \mathrm{yr}$ for the grout-data case with only an 8,000 -gal leak, compared to that reaching the water table in 1,000 yr for the 160,000 -gal leak case (P2-3).

Table 4-2 clearly shows the benefit of early emplacement of an infiltration barrier. By placing a temporary infiltration cover over the 241-AX Tank Farm immediately after sluicing, the percentage of contaminant mass reaching the water table can be reduced to $<1 \%$ during a $1,000 \mathrm{yr}$ period after sluicing. 
Table 4-2. Percentage of Contaminant Mass Reaching Water Table at Selected Times.

\begin{tabular}{|c|c|c|c|c|}
\hline Case & Description & $\begin{array}{l}\text { \% Reaching Water Table } \\
\text { in } 100 \mathrm{yr}\end{array}$ & $\begin{array}{l}\text { \% Reaching Water Table } \\
\text { in } 500 \mathrm{yr}\end{array}$ & $\begin{array}{l}\% \text { Reaching Water } \\
\text { Table in } 1,000 \mathrm{yr}\end{array}$ \\
\hline P4-2 & $\begin{array}{l}\text { Pre-sluicing leak } \\
\quad(160,000 \mathrm{gal})\end{array}$ & 46 & 83 & 90 \\
\hline P4-3 & $\begin{array}{c}\text { Pre-sluicing leaks } \\
(11,000 \text { gal }) \text { with } \\
40,000 \text {-gal sluicing leak }\end{array}$ & 5 & 48 & 69 \\
\hline P1-1 & $\begin{array}{c}\text { Grout performance } \\
\text { assessment } \\
\text { hydraulic data }\end{array}$ & 2 & 36 & 54 \\
\hline P2-3 & $\begin{array}{l}160,000 \mathrm{gal} \\
\text { sluicing leak }\end{array}$ & 6 & 38 & 53 \\
\hline P4-1 & $\begin{array}{l}\text { Pre-sluicing leaks } \\
\quad(11,000 \text { gals })\end{array}$ & 2 & 29.5 & 45 \\
\hline P4-1wo & $\begin{array}{l}\text { Pre-sluicing leaks, but } \\
\text { no sluicing leak }\end{array}$ & 2 & 28 & 43.5 \\
\hline $\mathrm{P} 2-2$ & 40,000 -gal sluicing leak & 1 & 21 & 36 \\
\hline P3-3 & $\begin{array}{l}4 \text { simultaneous leaks, with } 1 \\
\text { of } 40,000 \mathrm{gal}\end{array}$ & 0.7 & 18 & 30.5 \\
\hline P3-1 & $\begin{array}{l}2 \text { simultaneous sluicing } \\
\text { leaks ( } 8,000 \text { gal each) }\end{array}$ & 0.3 & 13.5 & 27.5 \\
\hline P3-2 & $\begin{array}{l}4 \text { simultaneous sluicing } \\
\text { leaks }(8,000 \text { gal each) }\end{array}$ & 0.3 & 13 & 26.5 \\
\hline P1-3 & $\begin{array}{l}50 \% \text { larger } \\
\text { model domain }\end{array}$ & 0.3 & 14 & 26 \\
\hline Baseline & $\begin{array}{c}8,000 \text {-gal sluicing leak for } 5 \\
\text { wk }\end{array}$ & 0.3 & 14 & 26 \\
\hline $\mathrm{P} 2 \cdot 5$ & $\begin{array}{c}8,000 \text {-gal sluicing leak for } 6 \\
\text { mo }\end{array}$ & 0.15 & 12 & 24.2 \\
\hline P2-1 & 4,000 -gal sluicing leak & 0.11 & 11 & 23 \\
\hline P2-4 & $\begin{array}{l}\text { Half-tank circumference } \\
\text { sluicing leak }\end{array}$ & 0.11 & 11 & 22.8 \\
\hline P1-2 & $\begin{array}{l}\text { No gravel correction of } \\
\text { hydraulic data }\end{array}$ & 0.1 & 9 & 21.8 \\
\hline P5-2 & $\begin{array}{c}\text { Permanent cover } 10 \mathrm{yr} \text { after } \\
\text { leak }\end{array}$ & $<0.01$ & 0.7 & 3.5 \\
\hline P5-3 & $\begin{array}{l}\text { Temporary cover } \\
\text { immediately after leak }\end{array}$ & $<0.01$ & 0.06 & 0.75 \\
\hline P5-1 & $\begin{array}{l}\text { Permancnt cover } \\
\text { immediately after leak }\end{array}$ & $<0.01$ & 0.02 & 0.37 \\
\hline
\end{tabular}


This table also shows that larger, single leaks have more effect on groundwater quality than a volumetrically equivalent number of smaller leaks. For example, one 160,000-gal leak has the same leak volume as twenty 8,000 -gal leaks, but the percentage of contaminant mass reaching the groundwater in $1,000 \mathrm{yr}$ from the 160,000 -gal leak is equivalent to forty 8,000 -gal leaks. This amplification results from the fact that a much larger percentage of the contaminant mass in a large leak reaches the water table in 1,000 yr. The amplification occurs because, at $100 \mathrm{yr}$ after sluicing, $6 \%$ of the larger contaminant mass from the 160,000 -gal leak has entered the water table. This mass is 20 times larger than the contaminant mass from the 8,000 -gal leak. In the latter, only $0.3 \%$ of the contaminant mass reaches the water table in $100 \mathrm{yr}(20 * 6 \% / 0.3 \%=400$ times more mass reaching the water table in $100 \mathrm{yr})$. In other words, based on the mass-flux to the water table within $100 \mathrm{yr}$ of sluicing, the 160,000 -gal leak is equivalent to four-hundred 8,000 -gal leaks.

Another important conclusion is that simultaneous sluicing leaks do not appear to enhance or amplify the effects on the water table caused by an equivalent volume from nonsimultaneous leaks. This result suggests that there is no reason, from the perspective of risk to groundwater quality, to prohibit the simultaneous sluicing of multiple tanks in the same tank farm. In any case, contamination from pre-sluicing leaks will likely reach the water table before contamination from a sluicing leak. A sluicing leak of 8,000 gal has no significant effect on the transport of contaminants in pre-sluicing leaks; however, a larger sluicing leak (e.g., 40,000 gal) discernibly enhances the transport of contaminants from pre-sluicing leaks.

\subsection{SUMMARY OF CONCLUSIONS}

In summary, important parameters affecting the transport of mobile contaminant species from the vadose zone to the water table are the following:

- Hydraulic Data

- Leak Volumes

- Infiltration Barriers.

Of these, the presence or absence of an infiltration barrier and its time of emplacement are the most important.

Without knowing the concentration of a contaminant in a specific sluicing leak, it is not possible to predict the risk to groundwater quality of leaks resulting from the sluicing of SSTs. However, if a significant percentage of contaminant mass from a leak reaches the water table, the risk to groundwater quality could be substantial if the contaminant concentration in the leak is high.

Contaminants from even small leaks will eventually reach the water table because of the volume of meteoric water infiltrating through the tank farm surface. It is this water which is the principal agent for driving the contaminant mass downward. However, if a barrier to infiltration can be emplaced over a tank farm shortly after sluicing, the risks are greatly diminished. 
If the volume of sluicing leaks approach or exceed 40,000 gal, then the leak volume, by itself, becomes a significant force for driving leaked contaminants to the water table. Hence, sluicing leaks of $\sim 40,000$ gal or more need to be avoided and/or mitigated.

In summary, if a barrier to infiltrating meteoric water is not emplaced soon after the completion of sluicing, even a small (e.g., 4,000 gal) sluicing leak may cause significant deterioration of groundwater quality. Alternatively, if there is little or no contaminant mass in the sluicing leak, then the allowable leakage could be much higher, except for very large leak volumes ( $>40,000 \mathrm{gal})$ which would still adversely affect any pre-existing contamination in the vadose zone.

\subsection{RECOMMENDATIONS}

Recommended responses based on the conclusions summarized above are as follow:

- Obtain better hydrogeologic data for the vadose zone of the tank farms

- Minimize the potential leak volumes from sluicing

- Design and install a temporary infiltration barrier as soon as possible after sluicing is completed

- Evaluate mitigation techniques for potential use if a large sluicing leak occurs

- Obtain better estimates of contaminant concentrations that would be present in sluicing leaks and analyze the risks to determine whether an infiltration barrier or mitigation system is needed

- Design and implement risk-based sensitivity analyses to refine the findings reported here. 


\subsection{REFERENCES}

Barnett, D. B., J. D. Davis, H. Hampt, J. W. Lindberg, K. F. Donnelson, 1996, Hanford Tanks Initiative Work Plan -- Subsurface Characterization to Support the ClosureReadiness Demonstration for Tank 241-AX-104, WHC-SD-WM-WP-337, Rev. 0, Westinghouse Hanford Company, Richland, Washington.

DOE and Ecology, 1996, Tank Waste Remediation System, Hanford Site, Richland, Washington, Final Environmental Impact Statement, DOE/EIS-0189, U. S. Department of Energy, Richland, Washington, and Washington State Department of Ecology, Olympia, Washington.

Hanlon, B. M., 1994, Tank Farm Surveillance and Waste Status Summary Report for March 1994, WHC-EP-0182-72, Westinghouse Hanford Company, Richland, Washington.

ICF KH, 1994, Historical Tank Content Estimate for the Northeast Quadrant of the Hanford 200 East Area, Work Order ER4945, WHC-SD-WM-ER-349, Rev. 0, prepared by ICF Kaiser Hanford for Westinghouse Hanford Company, Richland, Washington.

Iwatate, D. F., 1996, Proposed Strategy for Leak Detection, Monitoring, and Mitigation (LDMM) During Hanford Single-Shell Tank Waste Retrieval, WHC-SD-WM-ES-378, Rev. 0, Westinghouse Hanford Company, Richland, Washington.

Kincaid, C. T., J. W. Shade, G. A. Whyatt, M. G. Piepho, R. Rhoads, J. A. Voogd, J. H. Westsik, Jr., M. D. Freshley, K. A. Blanchard, B. G. Lauzon, 1995, Performance Assessment of Grouted Double-Shell Tank Waste Disposal at Hanford, WHC-SD-WM-EE-004, Rev. 1, Westinghouse Hanford Company, Richland, Washington.

Lowe, S., W. Carlos, J. Irwin, R. Khaleel, N. Kline, J. Ludowise, R. Marusich, P. Rittman, 1993, Engineering Study of Tank Leaks Related to Hydraulic Retrieval of Sludge from Tank 24I-C-106, WHC-SD-WM-ES-218, Westinghouse Hanford Company, Richland, Washington.

Piepho, M. G., 1994, Grout Performance Assessment Results of Benchmark, Base, Sensitivity and Degradation Cases, WHC-SD-WM-TI-561, Rev. 0, Westinghouse Hanford Company, Richland, Washington.

Runchal, A. K., and B. Sagar, 1993, PORFLOW: A Multifluid Multiphase Model for Simulating Flow, Heat Transfer, and Mass Transport in Fractured Porous Media Users Manual, NUREG/CR5991, U. S. Nuclear Regulatory Commission, Washington, D.C.

WHC, 1996, Hanford Tanks Initiative Plan, WHC-SD-WM-PMP-022, Rev. 0, Westinghouse Hanford Company, Richland, Washington. 
WHC-SD-WM-ANAL-052, Rev. 0

APPENDIX A

GEOLOGIC SETTING OF THE HANFORD SITE, 200 EAST AREA, AND 241-AX TANK FARM 
WHC-SD-WM-ANAL-052, Rev. 0

\section{CONTENTS}

A1.0 INTRODUCTION $\ldots \ldots \ldots \ldots \ldots \ldots \ldots \ldots \ldots \ldots \ldots \ldots \ldots \ldots \ldots$

A2.0 GEOLOGY OF THE HANFORD SITE AND 200 EAST AREA $\ldots \ldots \ldots \ldots$. . A-1

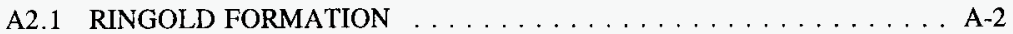

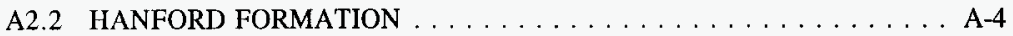

A2.3 SURFICIAL DEPOSITS $\ldots \ldots \ldots \ldots \ldots \ldots \ldots \ldots \ldots \ldots$

A3.0 HYDROLOGY OF THE HANFORD SITE AND 200 EAST AREA . . . . . . . A-5

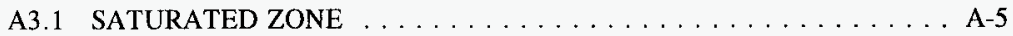

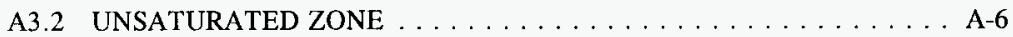

A3.3 VADOSE ZONE GEOLOGY OF THE 241-AX TANK FARM . . . . . A A-6

A3.3.1 Excavation Backfill . . . . . . . . . . . . . . A 6

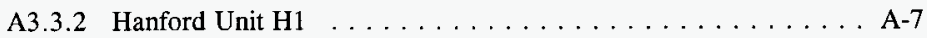

A3.3.3 Hanford Unit $\mathrm{H} 2 \ldots \ldots \ldots \ldots \ldots \ldots \ldots$ A $\ldots \ldots \ldots$

A3.3.4 Hanford Unit $\mathrm{H} 3 \ldots \ldots \ldots \ldots \ldots \ldots \ldots$. . . . . . . . . . . . . . . . . . . . . . .

A3.3.5 Ringold Formation . . . . . . . . . . . . . . A A-10

A4.0 241-AX TANK FARM VADOSE ZONE MODELS $\ldots \ldots \ldots \ldots \ldots \ldots \ldots$

A4.1 SIMPLIFIED CONCEPTUAL MODEL $\ldots \ldots \ldots \ldots \ldots \ldots \ldots \ldots$

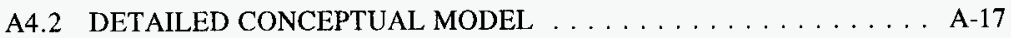

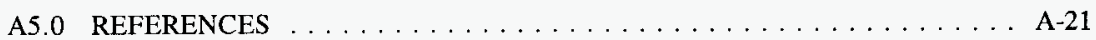

\section{FIGURES:}

A-1. Stratigraphic Units Found Adjacent to and Underlying the Hanford Site,

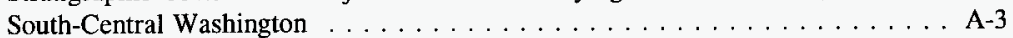

A-2. Structure Contour Map of the Top of Hanford Formation Unit H1

Beneath the 241 -AX Tank Farm . . . . . . . . . . . . . . . . A-8

A-3. Structure Contour Map of the Top of Hanford Formation Unit H2

Beneath the 241 -AX Tank Farm ... . . . . . . . . . . . . . . . A 9

A-4. Structure Contour Map of the Top of Hanford Formation Unit H3

Beneath the 241-AX Tank Farm ... . . . . . . . . . . . . . . . A-11

A-5. Structure Contour Map of the Top of Ringold Formation Lower Mud Unit

Beneath the 241-AX Tank Farm ... . . . . . . . . . . . . . . . A A-12

A-6. Structure Contour Map of the Top of Ringold Formation Unit A

Beneath the 241 -AX Tank Farm .................. A-13

A-7. Simplified Geologic Model Showing the Main Lithologic Units

Comprising the Vadose Zone Beneath the $241-$ AX Tank Farm . . . . . . . . A-16 
WHC-SD-WM-ANAL-052, Rev. 0

\section{CONTENTS (cont.)}

\section{FIGURES (cont.):}

A-8. Detailed Geologic Model Illustrating the Distribution of the Main Lithologies Comprising the Vadose Zone Beneath Tanks 241-AX-101 and $-103 \ldots \ldots \ldots$. . A-18 A-9. Detailed Geologic Model Illustrating the Distribution of the Main Lithologies Comprising the Vadose Zone Beneath the Center of the 241-AX Tank Farm .. . A-19 A-10. Detailed Geologic Model Illustrating the Distribution of the Main Lithologies Comprising the Vadose Zone Beneath Tanks 241-AX-102 and $-104 \ldots \ldots$. . . A-20 


\section{A1.0 INTRODUCTION}

Geologic logs of boreholes drilled in the 200 East Area typically have been constructed from descriptions of particle grain sizes in samples obtained from drill cuttings and split-spoon samplers. Consequently, most of these logs portray only large- to moderate-scale features.

Small-scale features and features not dependant on grain size (e.g., degree of cementation, compaction, matrix content, and bedding) have been described only in instances where such data are needed by a specific project, where pre-determined sampling intervals correspond with such features, or distinctive aspects of the samples were recognized for their geologic significance. Chip samples, typically taken at $5 \mathrm{ft}$ intervals, are routinely archived in the Hanford Geotechnical Sample Library. Saturated and unsaturated hydrologic parameters have been determined based on a relatively small number of aquifer tests, laboratory analyses, and flow-meter measurements.

\section{A2.0 GEOLOGY OF THE HANFORD SITE AND 200 EAST AREA}

The geology of the Hanford Site has been described in detail by DOE (1988), Delaney et al. (1991), Reidel et al. (1992), and Lindsey et al. (1994a,b). This section summarizes information contained in those reports. The Hanford Site is located within the Columbia Basin, a broad structural depression between the Cascade Range, Okanogan Highlands, northern Rocky Mountains, and Blue Mountains. The Columbia Basin is filled by a thick sequence of tholeiitic basalt flows called the Columbia River Basalt Group (CRBG) and thin sedimentary deposits of continental origin.

Folding and faulting in the Columbia Basin over the past 17-million yr has created broad structural and topographic basins separated by asymmetric anticlinal ridges. The Hanford Site occurs within one of the larger basins, the Pasco Basin. The Pasco Basin, the location of the Hanford Site, is bounded on the north by the Saddle Mountains and on the south by Rattlesnake Mountain and the Rattlesnake Hills. The Pasco Basin is divided into a series of east-west trending synclines by the Yakima Ridge and Umtanum Ridge anticlines. The largest syncline, the Cold Creek syncline, lies between Umtanum Ridge and Yakima Ridge and is the principal structure containing the Hanford Site waste management areas, including the 200 East Area and the 241-AX Tank Farm.

Overlying the CRBG in the synclinal basins is up to $1,700 \mathrm{ft}$ of sediment derived from continental sources. This sediment is late Miocene, Pliocene, and Pleistocene in age. In ascending order, the principal stratigraphic units underlying the Hanford Site are the Columbia River Basalt Group (Miocene), Ringold Formation (Miocene-Pliocene), PlioPleistocene unit (late Pliocene to early Pleistocene), and the Hanford formation (Pleistocene) 
(Figure A-1). The Plio-Pleistocene unit is not found beneath the 200 East Area where the 241-AX Tank Farm is located. A regionally discontinuous veneer of recent alluvium, colluvium, and/or eolian sediments overlies the principal geologic units. Backfill consisting of surficial Holocene sediments and Hanford formation is common at and adjacent to numerous Hanford Site facilities, and comprises the material above and between tanks in the tank farms.

The following sections describe various stratigraphic units found within the Hanford Site 200 East Area.

\section{A2.1 RINGOLD FORMATION}

The Ringold Formation consists of a heterogeneous mixture of variably cemented and compacted gravel, sand, silt, and clay. The strata that comprise the Ringold Formation record a history associated with the ancestral Columbia River system that occurred between 8.5 and 3.4 million years ago. The history is one of alluvial-lacustrine sedimentation and pedogenic activity (Fecht et al. 1987, Lindsey 1991, 1995, Reidel et al. 1994, Lindsey et al., 1994b).

Ringold strata are subdivided into a series of informal members defined on the basis of sediment types or dominant facies associations (Reidel et al., 1992; Lindsey et al., 1994a, 1994b; Lindsey 1991, 1995). Ringold Formation facies associations consist of fluvial graveldominated deposits (facies association I), fluvial sand-dominated deposits (facies association II), paleosols and overbank deposits (facies association III), lacustrine deposits (facies association IV), and alluvial fanglomerate (facies association V).

Ringold strata are grouped into three informal members defined on the basis of dominant facies associations at the type localities indicated by the member name: (1) the member of Wooded Island (facies association I, II, III, and IV); (2) the member of Taylor Flat (facies association II and III); and (3) the member of Savage Island (facies association IV) (Lindsey 1995). The member of Wooded Island is further subdivided into informal units defined by the presence of widespread fluvial gravel. These informal units are referred to as units A, B, C, D, and E (Reidel et al. 1992, Lindsey et al. 1994a, 1994b, Lindsey 1995). A widespread lacustrine-dominated interval, referred to as the lower mud unit, also occurs near the base of the member (Reidel et al. 1992, Lindsey et al. 1994a, 1994b, Lindsey 1995).

Beneath the 200 East Area the Ringold Formation is thin to absent. Where the Ringold Formation is present in the 200 East Area, only unit A, the lower mud unit, and unit $\mathrm{E}$ are found. In the 200 East Area, these units may be erosional remnants. Descriptions of the Ringold Formation beneath the 200 East Area are found in Lindberg et al. (1992), Lindsey et al. (1992, 1994a, 1994b), and Lindsey (1995). 
Figure A-1. Stratigraphic Units Found Adjacent to and Underlying the Hanford Site, South-Central Washington (from Lindsey 1995). (Column not to scale)

Age Epoch Formation

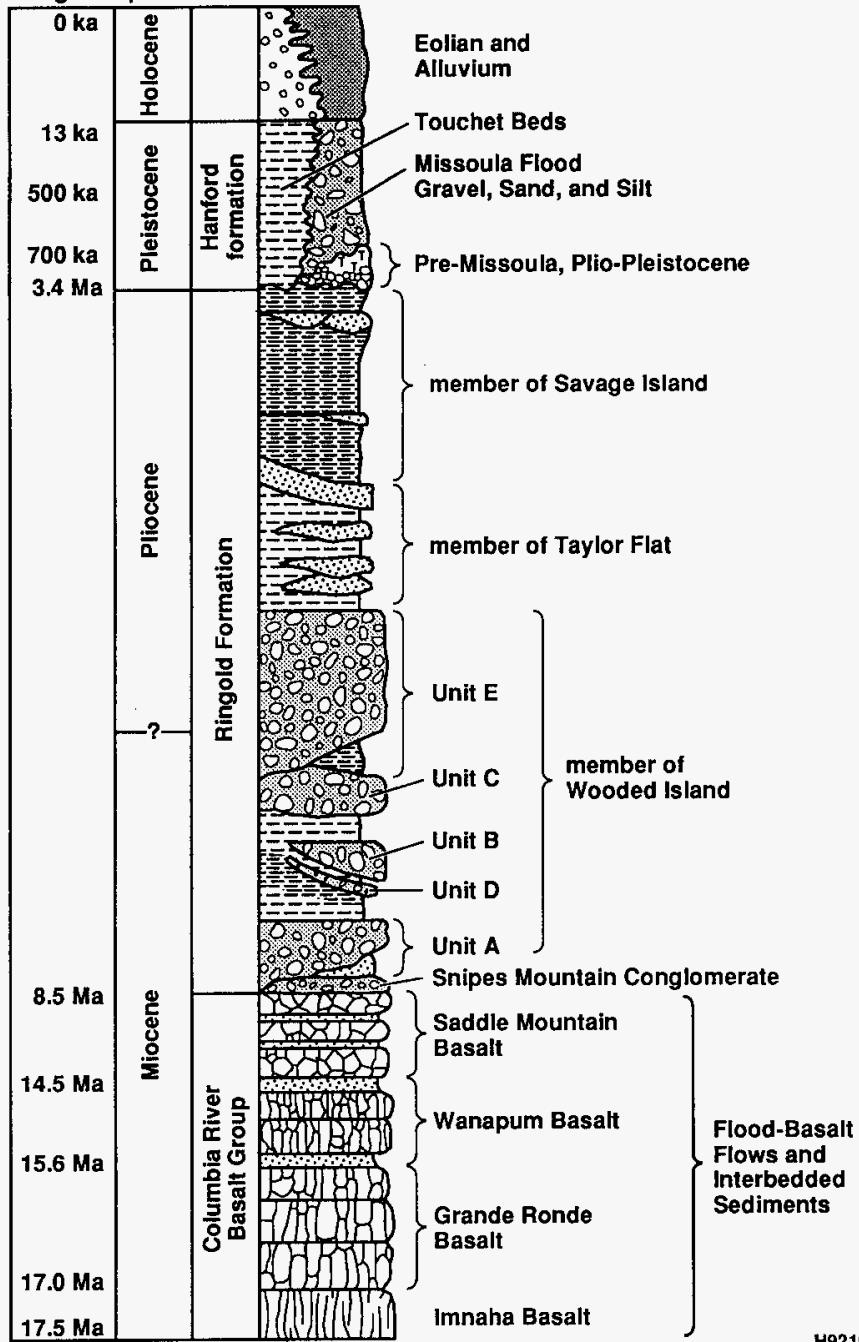

H9210011.1b 


\section{A2.2 HANFORD FORMATION}

The Hanford formation is an informal name applied to clastic sediments of terrigenous origin displaying distinctive physical properties attributed to deposition by Pleistocene (2 million yr to 10,000 yr ago) cataclysmic floods (Tallman et al. 1979, 1981; DOE 1988; Baker at al. 1991). Evidence has been found for at least four major cataclysmic flood sequences in and around the Hanford Site. Three principal types of sedimentary deposits were left behind by the floods: (1) high-energy deposits consisting of gravel and sand of the Paco Gravels, (2) low-energy, slackwater deposits consisting of rhythmically bedded silt and sand of the Touchet Beds, and (3) coarse- to fine-grained sand deposits representing a transitional environment between the other two facies.

The Hanford formation typically is divided into several sediment types, facies, or lithologies based on grain size and sedimentary structures related to depositional energy. The Hanford formation thickens from $\sim 20 \mathrm{ft}$ in parts of the 200 West Area to $\sim 300 \mathrm{ft}$ in parts of the 200 East Area. Recent reports relating to the Hanford formation (Reidel et al. 1992, Lindsey et al. 1994a, 1994b) recognize three principal facies: (1) gravel-dominated, (2) sand-dominated, and (3) silt-dominated. These facies generally correspond to the coarsegrained gravels, laminated sands, and graded rhythmites, respectively, of DOE (1988), Baker et al. (1991), and Delaney et al. (1991).

The gravel-dominated facies consists of coarse-grained sand and granule- to bouldersized gravel displaying massive bedding, plane to low-angle bedding, and large-scale cross-bedding in outcrop. Matrix commonly is lacking from the gravel, resulting in an open-framework texture. The sand-dominated facies consists of fine- to coarse-grained sand and small pebbles that display plane lamination and bedding planes and trough cross-bedding in outcrop. Small pebbles and pebbly or silty interbeds ( 8 in. thick) locally may be present. Where silt content is low, an open-framework texture can occur. The silt-dominated facies consists of planar to tabular horizons of silt and fine- to coarse-grained sand forming normally graded beds $<1 \mathrm{~m}$ thick. Plane lamination and ripple cross-lamination is common in outcrop. The three facies are inter-gradational.

Hanford formation strata are locally subdivided into a series of stratigraphic units of variable thickness and lateral extent. In the 200 East Area these units are referred to as unit $\mathrm{H} 1$ (consisting of gravel and lesser sand facies), unit H2 (consisting of sand and silt facies), and $\mathrm{H} 3$ (consisting of interbedded gravel and sand facies). Contacts between these units typically are not sharp; gradational contacts and interfingering of units are the norm.

\section{A2.3 SURFICIAL DEPOSITS}

Surficial deposits of Holocene age consist of silt, sand, and gravel. These lithologies form a thin $(<16 \mathrm{ft})$ veneer across much of the Hanford Site (DOE 1988). In the southern part of 200 East Area, these deposits consist principally of laterally discontinuous sheets of wind-blown silt and fine-grained sand. At and near facilities such the Hanford Site tank 
farms, the backfill typically is locally derived from the surficial deposits and Hanford formation.

\section{A3.0 HYDROLOGY OF THE HANFORD SITE AND 200 EAST AREA}

Hanford Site hydrogeology is discussed in several reports (DOE 1988; Gephart et al. 1979; Graham et al. 1981, 1984; Law et al. 1987; and Delaney et al. 1991). This section summarizes available information.

The Hanford Site has a semiarid climate and averages 6.25 in. of precipitation per year. Recharge rates may range from near 0 to $>4$ in./yr, depending on surface conditions (Gee 1987; Routson and Johnson 1990). Low recharge rates occur where fine-textured sediments are present at the surface and where deep-rooted plants are abundant. Larger recharge values occur in areas where coarse-grained gravelly sediments are present at the surface and there is no vegetative cover (e.g., in disturbed areas such as the tank farms). Wastewater ponds, cribs, and ditches associated with past nuclear fuel processing and waste disposal activities are also present on the Hanford Site.

\section{A3.1 SATURATED ZONE}

The saturated zone in the Pasco Basin is characterized by a multi-aquifer system consisting of four hydrogeologic units corresponding to the upper three formations of the CRBG and the sediments overlying the basalts. The basalt aquifers are confined and consist of the CRBG flood basalts and relatively minor amounts of intercalated fluvial and volcaniclastic sediments of the Ellensburg Formation. Confined zones in the basalt aquifers are present in the sedimentary interbeds and/or interflow zones that occur between dense basalt flows. The main water-bearing portions of the interflow zones are networks of interconnecting vesicles and fractured flow tops and flow bottoms (DOE 1988). The aquifer above the basalt is a regionally unconfined aquifer and is contained largely within sediments of the Ringold and Hanford formations.

The uppermost aquifer beneath the Hanford Site is at depths ranging from $1 \mathrm{ft}$ below ground surface near West Lake and the Columbia and Yakima Rivers to $350 \mathrm{ft}$ in the central part of the Cold Creek syncline. The water table in the western part of the Hanford Site is generally within Ringold unit $\mathrm{E}$ gravels. The water table in the eastern part of the Hanford Site is generally within the Hanford formation.

Beneath most of the 200 East Area the water table commonly is in the immediate vicinity the Hanford formation-Ringold Formation contact. The bottom of the uppermost aquifer is defined as the top of the uppermost basalt flow. However, fine-grained overbank and lacustrine deposits in the Ringold Formation locally confine groundwater in the Ringold 
fluvial gravels underlying gravel unit A. The uppermost aquifer is bounded laterally by anticlinal basalt ridges and is $\sim 500 \mathrm{ft}$ thick near the center of the Pasco Basin. Hydraulic conductivities for the Hanford formation (2,000 to $10,000 \mathrm{ft} /$ day) are much larger than those of the gravel facies of the Ringold Formation (610 to 3,050 ft/day) (Graham et al. 1981).

\section{A3.2 UNSATURATED ZONE}

The dominant vadose zone geologic unit is the Hanford formation. Vadose zone physical conditions across the Hanford Site and within the 200 Areas vary in a manner similar to those in the uppermost aquifer. Vadose zone sediments range from open-framework gravel and interbedded silt and sand of the silt-dominated facies of the Hanford formation, to the calcium-carbonate-rich lithology of the Plio-Pleistocene unit, to cemented gravel of the Ringold Formation.

Van Genuchten curve-fitting parameters for the major stratigraphic units beneath the 200 Areas are summarized in Connelly et al. (1992a, 1992b) and Khaleel and Freeman (1995). Examination of the data in these reports reveals that these curve-fitting parameters are highly variable, and that an accurate assessment of them depends on site-specific data. Beneath the 200 East Area, vadose zone lithologies are dominated by uncemented sand-dominated facies; in addition, there are minor intercalated gravel- and silt-dominated facies.

\section{A3.3 VADOSE ZONE GEOLOGY OF THE 241-AX TANK FARM}

The vadose zone beneath the 241-AX Tank Farm is comprised almost entirely of the Hanford formation. The bottom few meters of the vadose zone extends into the top of the Ringold Formation. Tank farm backfill derived mostly from the Hanford formation forms the uppermost part of the vadose zone.

The following discussion of vadose zone geology for the 241-AX Tank Farm is based on data and interpretations in Price and Fecht (1976), Caggiano and Goodwin (1991), Lindsey and Law (1993), borehole logs from the tank farm and vicinity, grain-size data in the ROCSAN database, and analysis of geologic features found elsewhere that are interpreted to be analogous to those at the tank farm.

\section{A3.3.1 Excavation Backfill}

Backfill consists of slightly pebbly to slightly silty, coarse to fine sand (Price and Fecht 1976) removed from the original excavation and later returned during tank farm construction. Available information indicates the backfill was not engineered, although it was returned to the excavation in lifts, resulting in varying degrees of compaction from day-to-day construction activity. Backfill ranges from 0 to $55.8 \mathrm{ft}$ thick at the 241-AX Tank Farm. 


\section{A3.3.2 Hanford Unit H1}

The uppermost 0 to $50 \mathrm{ft}$ beneath the base of the tanks in the 241-AX Tank Farm consists of a westward thinning sequence of slightly silty, pebbly, very coarse to coarse sand and sandy, fine to very fine pebble gravel to pebbly, very coarse sand (Price and Fecht 1976) assigned to unit H1. These strata are interpreted to be interbedded sand and gravel facies, with gravel beds generally thinning to the west and south. This interval is divided into an upper, laterally discontinuous, sand-rich interval designated H1A and a lower, more gravelrich interval designated $\mathrm{H} 1$. Units $\mathrm{H} 1$ and $\mathrm{H} 1 \mathrm{~A}$ interfinger. The top of unit $\mathrm{H} 1$ ranges from $625 \mathrm{ft}$ to $590 \mathrm{ft}$ above mean sea level (Figure A-2).

Throughout units $\mathrm{Hl}$ and H1A, bedding typically is laterally discontinuous, with interfingering sand- and gravel-rich horizons forming a complex series of tabular and wedgeshaped lenses. Grain size data, borehole log descriptions, and exposures in excavations such as described by Goldstrand (1984) suggest that pebbles $(2 \mathrm{~mm}$ to $64 \mathrm{~mm})$ dominate the gravel fraction. Total gravel content varies from 10 to $51 \mathrm{wt} \%$ in samples from units $\mathrm{H} 1$ and H1A.

There is no direct evidence of clay- or silt-rich horizons beneath the 241-AX Tank Farm. However, outcrops at the scale of individual tank farms (tens of meters) do occasionally contain clayey/silty lenses, as well as laterally persistent clayey/silty interbeds within gravel- and sand-dominated facies. Samples with clay and silt contents in excess of $20 \mathrm{wt} \%$ are also indicative of the presence of fine-grained horizons.

\section{A3.3.3 Hanford Unit H2}

Unit $\mathrm{H} 1$ is underlain by 114 to $151 \mathrm{ft}$ of slightly silty, very coarse to medium sand (Price and Fecht 1976) assigned to unit H2. Based on these descriptions, and examinations of borehole geologic logs and outcrops of analogous strata, the lithologies comprising unit $\mathrm{H} 2$ are interpreted to be dominated by well-stratified sand typical of the sand-dominated facies.

Although not explicitly described in logs of boreholes for the 241-AX Tank Farm, the sandy strata forming unit $\mathrm{H} 2$ are inferred to contain thin $(<1.6 \mathrm{ft})$, lenticular interbeds of silt. This interpretation is based on the presence of clay/silt-rich ( $>20 \mathrm{wt} \%$ ) samples in the ROCSAN database, borehole geologic logs from similar strata at other locations (Lindsey et al. 1992, 1994b), three cross-sections of the nearby 241-A Tank Farm showing clayey/silty horizons (Caggiano and Goodwin 1991), and the appearance of silty interbeds in analogous sand-dominated outcrops (Lindsey et al. 1994a).

Borehole logs, in conjunction with grain size data in ROCSAN, indicate the presence of gravelly sand intervals as thick as $23 \mathrm{ft}$ in unit $\mathrm{H} 2$. Several gravelly intervals appear to laterally persist beneath the entire 241-AX Tank Farm. The top of unit $\mathrm{H} 2$ ranges from $\sim 613$ to $570 \mathrm{ft}$ above mean sea level (Figure A-3). 
WHC-SD-WM-ANAL-052, Rev, 0

Figure A-2. Structure Contour Map of the Top of Hanford Formation Unit H1 Beneath the 241-AX Tank Farm.

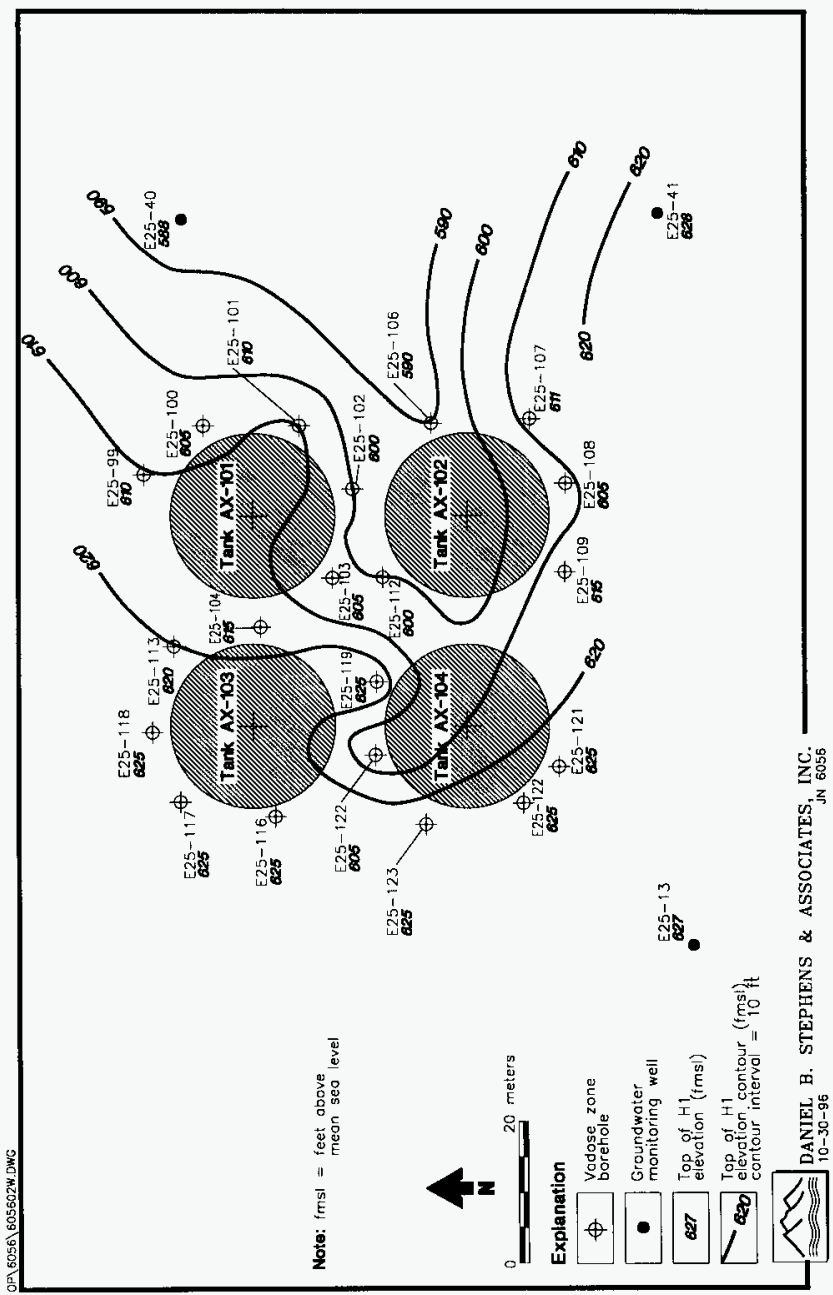


Figure A-3. Structure Contour Map of the Top of Hanford Formation Unit H2 Beneath the 241-AX Tank Farm.

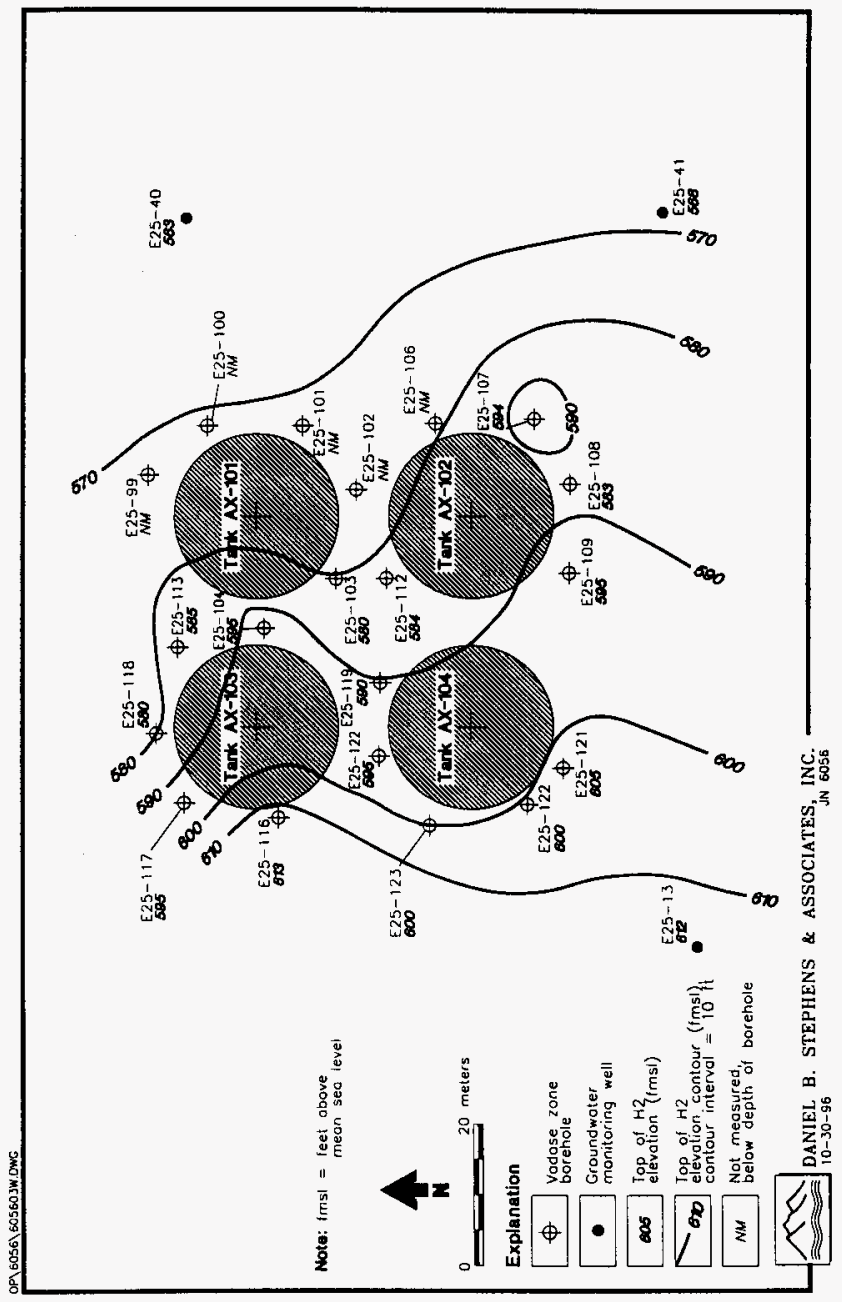




\section{A.3.3.4 Hanford Unit $\mathrm{H3}$}

The lower part of the Hanford formation consists of an interstratified sequence of sand and gravel facies referred to as unit H3. Only three boreholes near the 241-AX Tank Farm are sufficiently deep to reach unit H3. Consequently, physical characteristics for this unit are largely inferred. The small amount of information available suggests that the bedding geometries and clay/silt content of unit $\mathrm{H} 3$ are similar to those of unit $\mathrm{H} 1$. However, the number, thickness, and lateral extent of individual gravel beds in this unit may be less than in unit $\mathrm{H} 1$. Unit $\mathrm{H} 3$ ranges from $\sim 33$ to $46 \mathrm{ft}$ thick. The top of the unit $\mathrm{H} 3$ ranges from $\sim 450$ to $465 \mathrm{ft}$ above sea level (Figure A-4).

\section{A3.3.5 Ringold Formation}

The lower mud unit of the Ringold Formation is the deepest stratigraphic unit of the vadose zone beneath the 241-AX Tank Farm. The unit consists of silt- and clay-dominated lacustrine and overbank deposits of facies associations IV and III, respectively. In the vicinity of the 241-AX Tank Farm, the lower mud unit is believed to range from $\sim 10$ to $28 \mathrm{ft}$ thick, with the top of the unit dipping to the northwest. The top of the unit ranges from $\sim 421$ to $413 \mathrm{ft}$ above sea level (Figure A-5).

The water table is $\sim 10$ to $16.4 \mathrm{ft}$ below the top of the lower mud unit. Because only three boreholes in the vicinity of the 241-AX Tank Farm are sufficiently deep to intersect the lower mud unit, its continuity beneath the 241-AX Tank Farm is unknown. Absence of the lower mud unit from boreholes at other nearby facilities suggests that it may not completely underlie the tank farm. If the lower mud unit is absent beneath all or part of the 241-AX Tank Farm, the water table will be located in Ringold unit A. Unit A consists of consolidated, variably cemented fluvial sand and gravel. The top of unit $A$ in the vicinity of the 241-AX Tank Farm is at an elevation $\sim 398$ to $404 \mathrm{ft}$ above sea level (Figure A-6).

\section{A4.0 241-AX TANK FARM VADOSE ZONE MODELS}

The hydrogeology described in Sections A2.0 and A3.0 provides the physical basis for the conceptual models that were numerically simulated for the sensitivity analyses of this report. For purposes of the numerical simulations, two conceptual models were developed. They can be categorized as:

$$
\begin{array}{ll}
-\quad \text { Simplified } \\
\text { - } & \text { Detailed. }
\end{array}
$$


Figure A-4. Structure Contour Map of the Top of Hanford Formation Unit H3 Beneath the 241-AX Tank Farm.

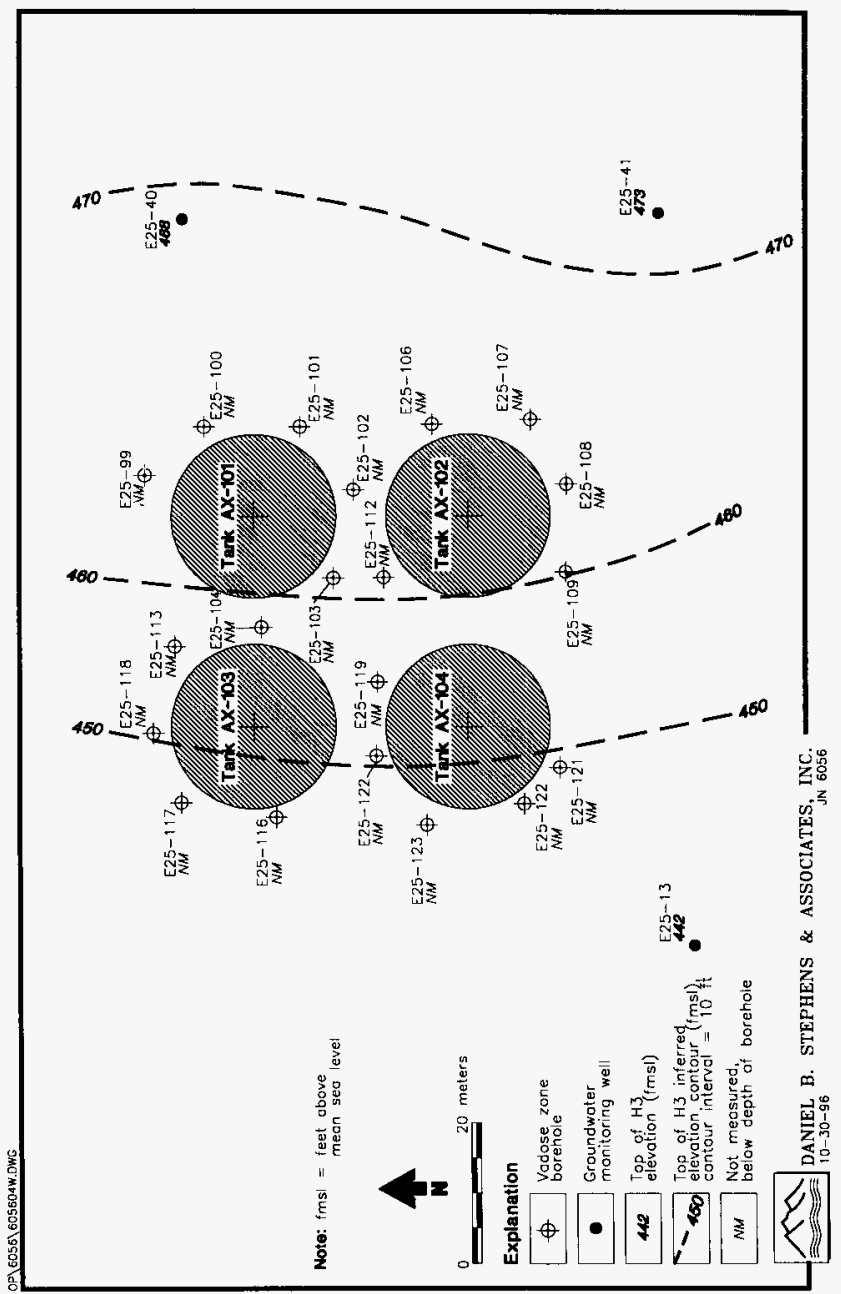


Figure A-5. Structure Contour Map of the Top of the Ringold Formation Lower Mud Unit Beneath the 241-AX Tank Farm.

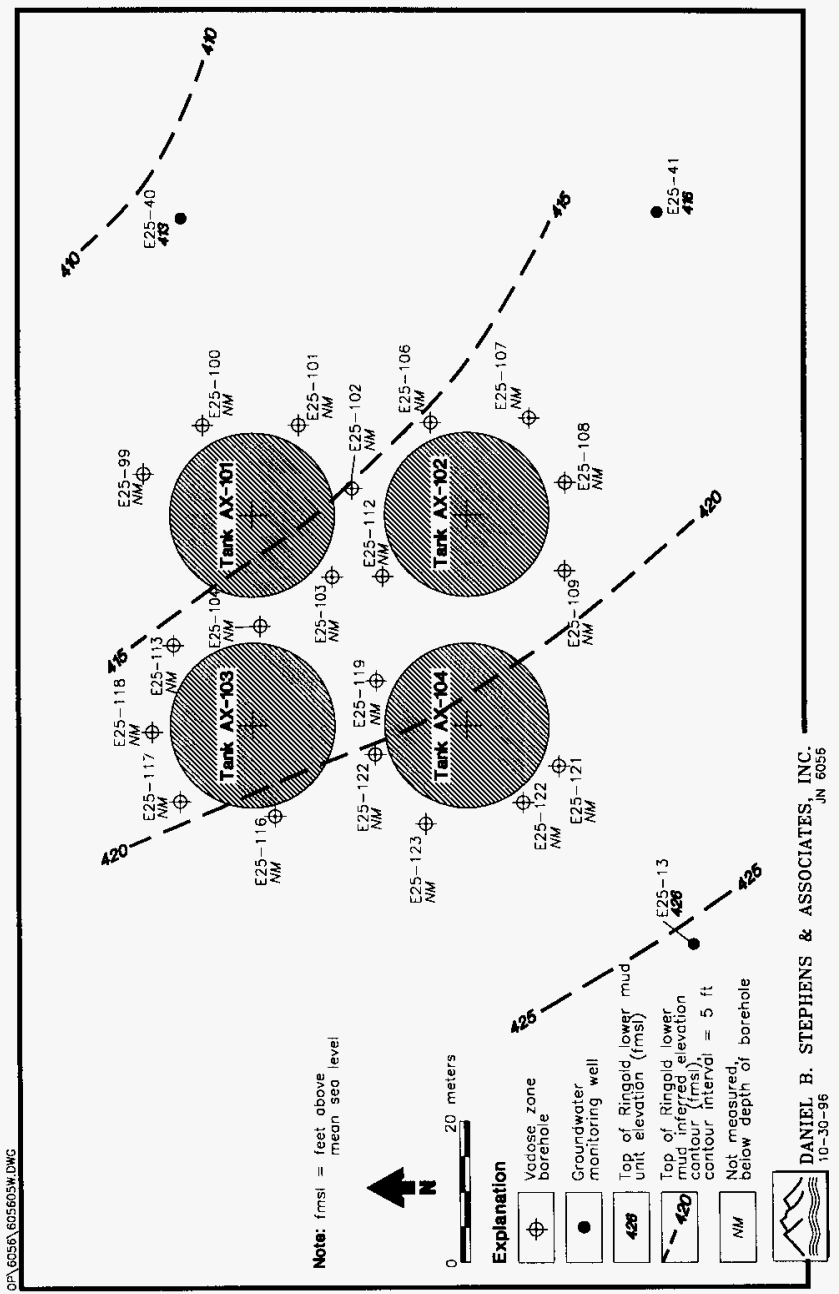


Figure A-6. Structure Contour Map of the Top of the Ringold Formation Unit A Beneath the 241-AX Tank Farm.

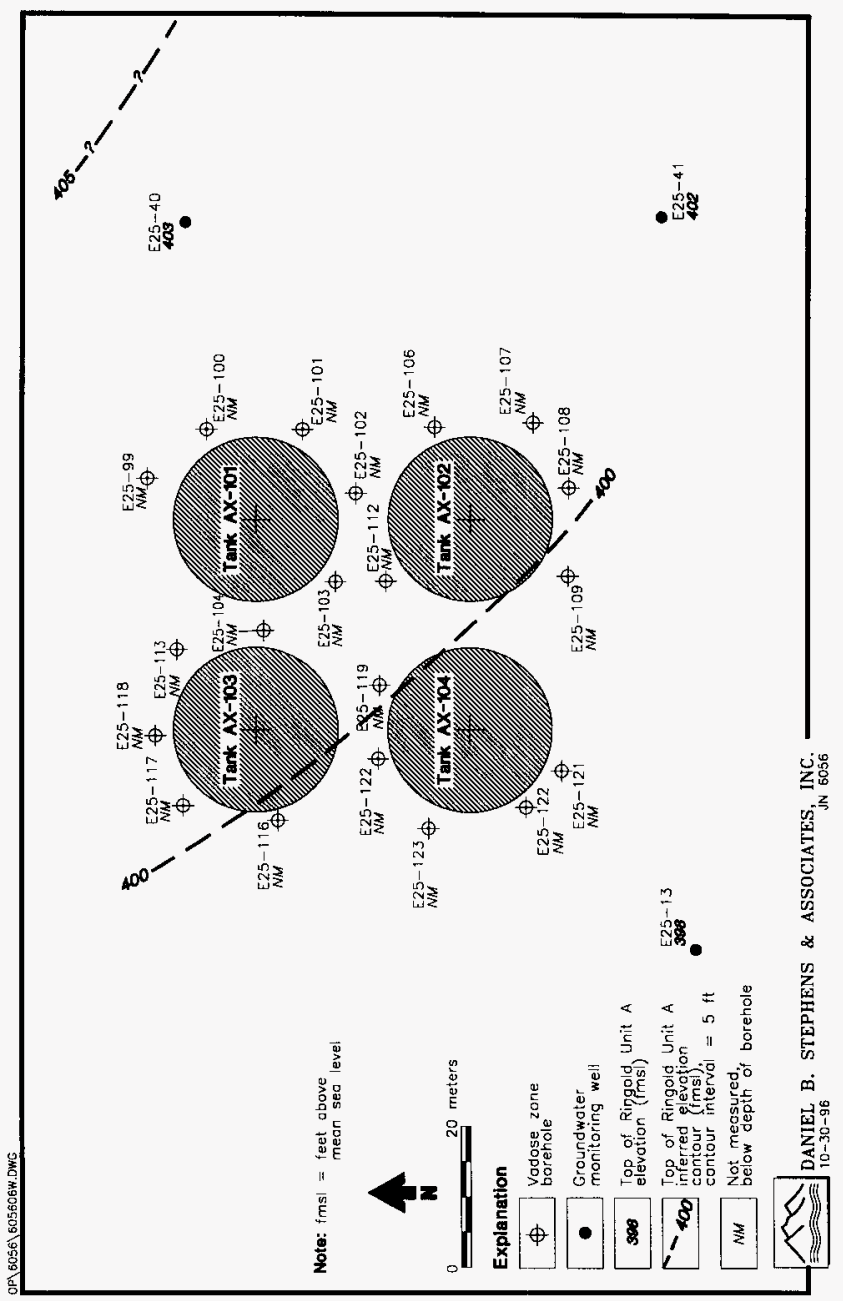


The simplified geologic model minimizes variations attributable to relatively smallscale allogenic or authigenic features. The geologic irregularities and variation observed and inferred beneath the 241-AX Tank Farm were neglected in the simplified conceptual model to expedite the tasks required for its numerical simulation.

The detailed geologic model portrays the best current knowledge of the local, threedimensional variability in unit thickness and depth beneath the tank farm. Stratigraphic units in the two models were identified using the same numbering system (e.g., 1, 2, 2A, 3, etc.). However, except for similarities in physical properties (e.g., unit 2 is always an upper Hanford formation gravelly interval), units in the two conceptual models with the same identifying number do not necessarily have the same vertical and lateral distribution. These differences reflect the differing assumptions and simplifications inherent in the two conceptual models.

For both conceptual models, internal physical characteristics (e.g. grain size, sorting, and packing) were assumed to be constant for each specified lithologic unit. This assumption was made because the magnitude of uncertainties associated with the data may in many instances outweigh the validity of detailed inferences from the data. These uncertainties stem from the following:

- Data on particle-size distributions in sediments that underlie the 241-AX Tank Farm were derived from samples that may not have been described in a consistent manner, using common criteria

- All samples may not have been collected using the same procedures

- The prescribed sampling intervals for the tank farm drywells may have resulted in failure to sample all lithologic types encountered.

As a consequence of these factors, detailed correlations based on literal interpretation of the available geologic logs and grain size data are as likely to reflect sampling and descriptive bias as the actual geology.

In addition to uncertainties associated with sampling and descriptive aspects of available data, interpretation of the data is hampered by the lack of hydraulic properties data from the vicinity of the 241-AX Tank Farm, and the absence of vadose zone data of any kind from many areas of interest. The relevance of data from other locations to the hydraulic properties of lithologies beneath the 241-AX Tank Farm cannot easily be established. This difficulty results from ambiguous sample descriptions, differences and inadequacies of sampling techniques, and/or changes in physical properties of the same strata between the 241AX Tank Farm and other locations. 


\section{A4.1 SIMPLIFIED CONCEPTUAL MODEL}

Lithologic descriptions that form the framework for the simplified conceptual model are based on inferences drawn from groundwater monitoring wells near the 241-AX Tank Farm and wells that penetrate similar strata elsewhere on the Hanford Site, from grain size data in the ROCSAN database, and from information in Fecht and Price (1976).

Using these sources, a simplified conceptual model of the hydrogeology of the 241-AX Tank Farm was constructed that portrays current hydrogeologic knowledge for the 241-AX Tank Farm. This interpretation minimizes the local lithologic and stratigraphic heterogeneities that likely are present. The model depicted in Figure A-7 is based on information from three groundwater monitoring wells near the 241-AX Tank Farm (299-E25-13, 299-E25-40, and 299-E25-41), supplemented by information from the 241-AX Tank Farm drywells and excavation.

The hydrogeologic parameters for each lithology are listed in Appendix B. A concise geologic description of each lithology from the surface downward is as follows:

$I$ - Backfill consisting of pebbly sand and sand; $16.2 \mathrm{~m}$ thick

2 - Interbedded sand- and gravel-dominated facies; dips eastward, dominated by lenticular bedding geometries; $5.2 \mathrm{~m}$ thick

3 - Sand-dominated facies with minor silt and sand interbeds; forms an eastwardthinning wedge; $12.2 \mathrm{~m}$ thick

4 - Sand-dominated facies containing intercalated, lenticular gravel; lithology is planar and continuous beneath the tank farm; $3.5 \mathrm{~m}$ thick

5 - Sand-dominated facies with minor, intercalated lenses of the gravel-and siltdominated facies; $9.1 \mathrm{~m}$ thick

6 - Interbedded sand- and gravel-dominated facies; forms an eastward-thinning wedge; $6.1 \mathrm{~m}$ thick

7 - Sand-dominated facies with lenticular interbeds of the silt-dominated facies inferred to be present; gravel rare to absent; $\sim 20.3 \mathrm{~m}$ thick

8 - Interbedded sand-and gravel-dominated facies; westward-thinning; $9.1 \mathrm{~m}$ thick

$9 a$ - Ringold lacustrine clay and silt; water table located $3.1 \mathrm{~m}$ below top of stratum. 
Figure A-7. Simplified Geologic Model Showing the Main Lithologic Units Comprising the Vadose Zone Beneath the 241-AX Tank Farm.

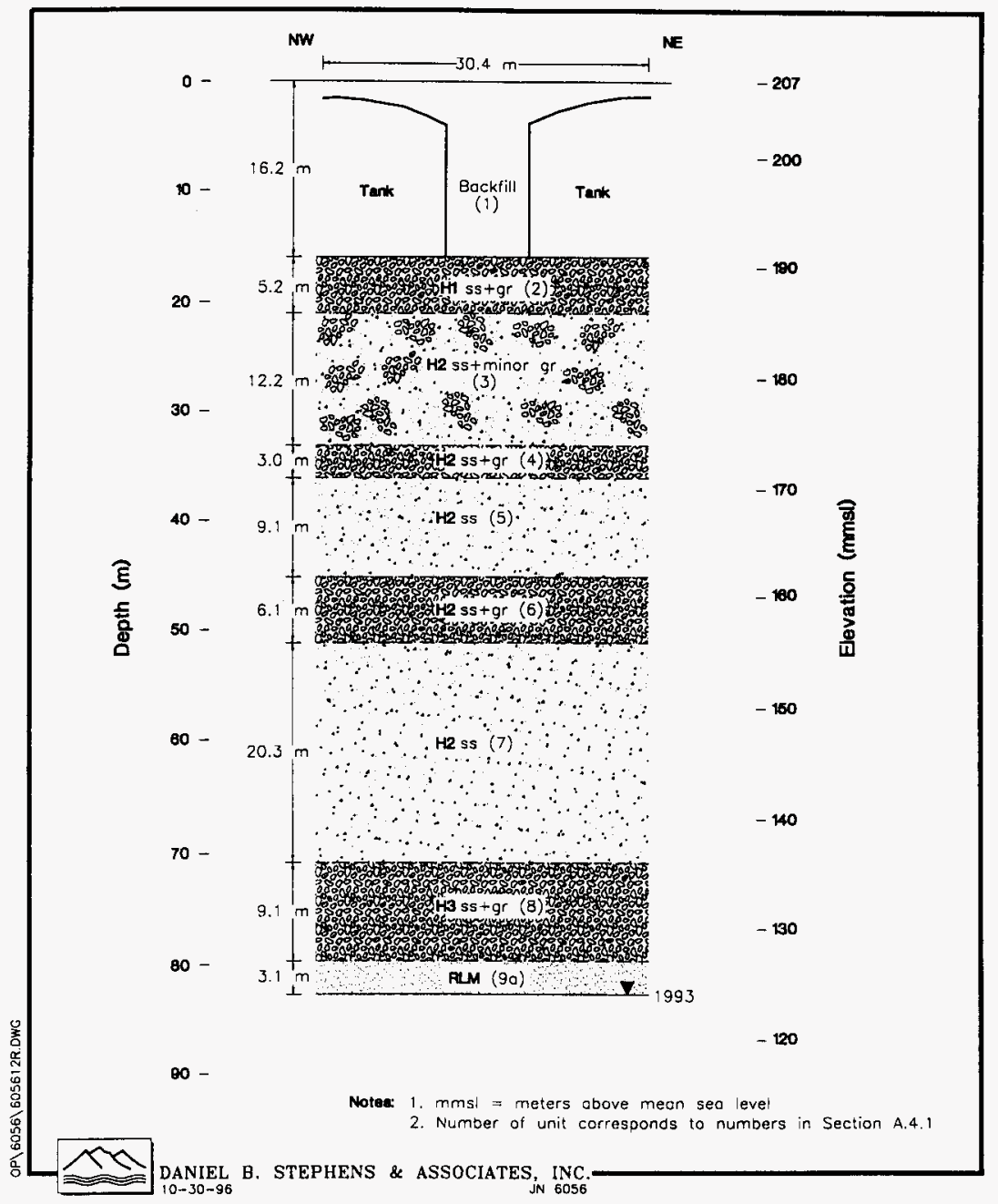




\section{A4.2 DETAILED CONCEPTUAL MODEL}

This conceptual model, based on the same information used for the simplified conceptual model, is considered to be a "best estimate" of hydrogeologic conditions beneath the 241-AX Tank Farm. However, the presence, thickness, and extent of each lithology potentially present is not portrayed because of the limitations discussed earlier. The detailed model portrays the main geologic intervals interpreted to be present and their inferred lateral variation (including thickening and thinning, pinchouts, and interfingering). The detailed conceptual model is shown as three geologic cross-sections (Figures A-8, -9, and -10).

The hydrogeologic parameters for each lithology are listed in Appendix B. A concise geologic description of each lithology from the surface downward is as follows:

$I$ - Backfill consisting of pebbly sand and sand; $16.2 \mathrm{~m}$ thick

$2 a$ - Sand-dominated facies with intercalated pebble gravel; forms a westwardthinning wedge; 0 to $9.8 \mathrm{~m}$ thick

2 - Interbedded sand- and gravel-dominated facies; dips eastward; dominated by lenticular bedding geometries; 5 to $7.8 \mathrm{~m}$ thick

3 - Sand-dominated facies with minor silt and sand interbeds; forms an eastwardthinning wedge, 2 to $9 \mathrm{~m}$ thick

4 - Sand-dominated facies containing intercalated, lenticular gravel; planar and continuous beneath the 241-AX Tank Farm; $3.5 \mathrm{~m}$ thick

5 - Sand-dominated facies with minor, intercalated lenses of the gravel- and siltdominated facies; 8.5 to $11.5 \mathrm{~m}$ thick

6 - Interbedded sand- and gravel-dominated facies; forms an eastward-thinning wedge; 0 to $7 \mathrm{~m}$ thick

7 - Sand-dominated facies with lenticular interbeds of the silt-dominated facies inferred to be present; gravel rare to absent; $\sim 18 \mathrm{~m}$ thick

8 - Interbedded sand- and gravel-dominated facies, westward-thinning; 10 to $14 \mathrm{~m}$ thick

9 - Ringold gravel facies; probably entirely within saturated zone, although locally may extend upward into the vadose zone

$9 a$ - Ringold lacustrine clay and silt; water table located 2.9 to $4.9 \mathrm{~m}$ below top of stratum. 
Figure A-8. Detailed Geologic Model Illustrating the Distribution of the Main Lithologies Comprising the Vadose Zone Beneath Tanks 241-AX-101 and -103.

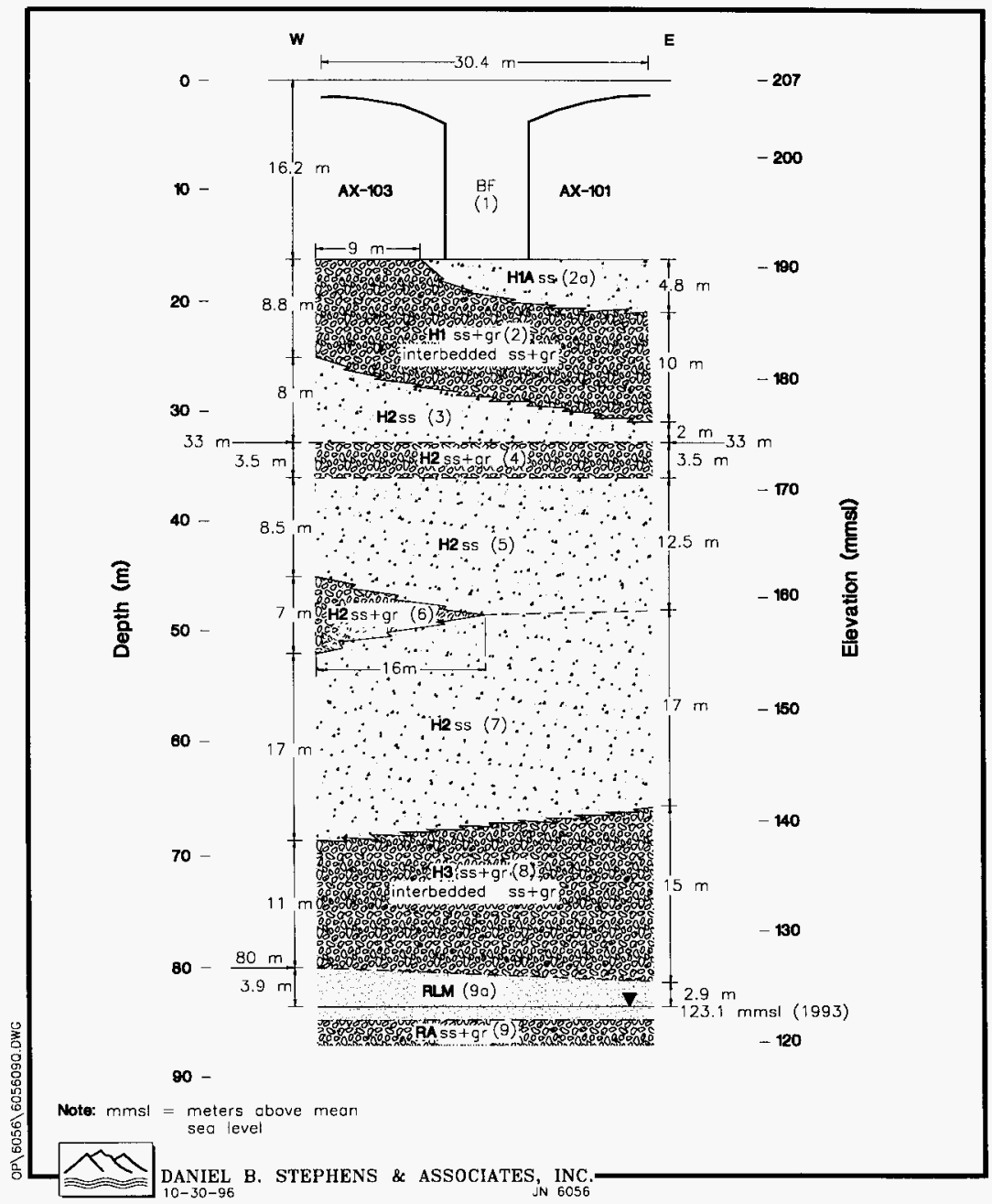


Figure A-9. Detailed Geologic Model Illustrating the Distribution of the Main Lithologies Comprising the Vadose Zone Beneath the Center of the 241-AX Tank Farm.

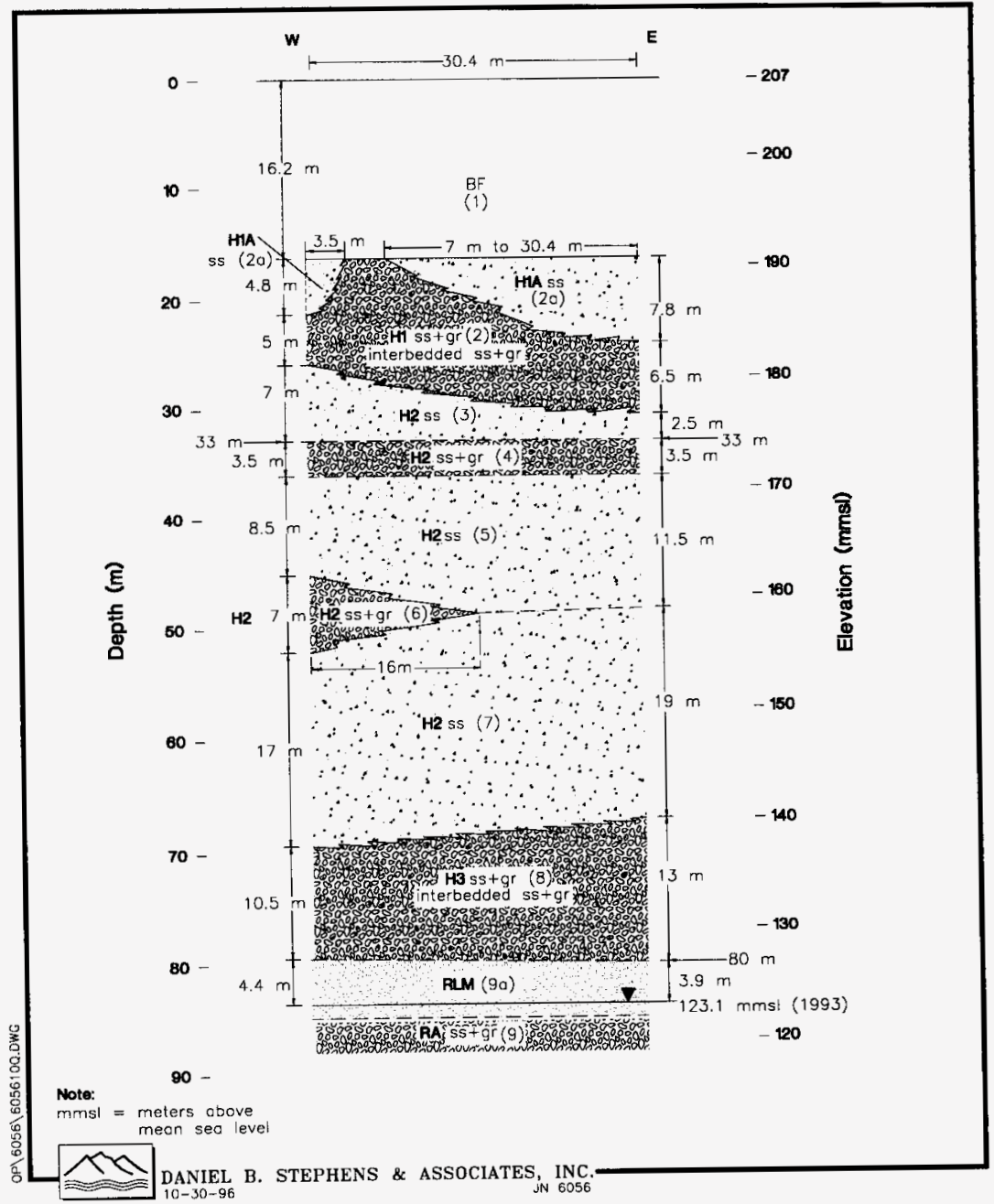


Figure A-10. Detailed Geologic Model Illustrating the Distribution of the Main Lithologies Comprising the Vadose Zone Beneath Tanks 241-AX-102 and -104.

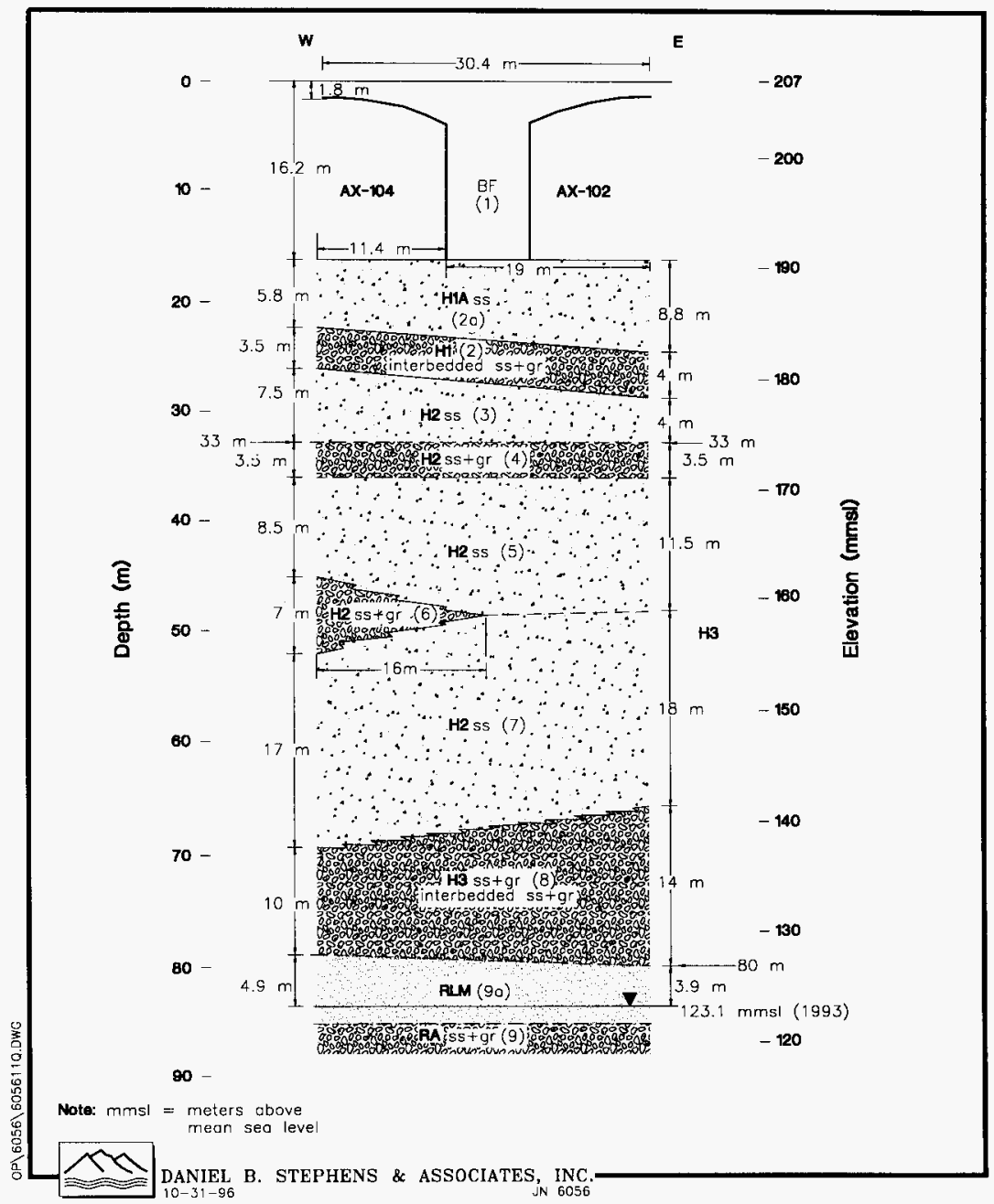




\section{A5.0 REFERENCES}

Baker, V. R., B. N. Bjornstad, A. J. Busacea, K. R. Fecht, E. P. Kiver, U. L, Moody, J. G. Rigby, O. F. Stradling, and A. M. Tallman, 1991, Quaternary Geology of the Columbia Plateau, in Morrison, R.B., editor, Quaternary Nonglacial Geology; Conterminous United States. The Geology of North America, vol. K-2, Geological Society of America, Boulder, Colorado, p. 215-250.

Caggiano, J. A. and S. M. Goodwin, 1991, Interim Status Groundwater Monitoring Plan for the Single-Shell Tanks, WHC-SD-EN-AP-012, Westinghouse Hanford Company, Richland, Washington.

Connelly, M. P., J. V. Borghese, C. D. Delaney, B. H. Ford, J. W. Lindberg, and S. J. Trent, 1992a, Hydrogeologic Model for the 200 East Groundwater Aggregate Area, WHC-SD-EN-TI-019, Rev. 0, Westinghouse Hanford Company, Richland, Washington.

Connelly, M. P., B. H. Ford, and J. V. Borghese, 1992b, Hydrogeologic Model for the 200 West Groundwater Aggregate Area, WHC-SD-EN-TI-014, Rev. 0, Westinghouse Hanford Company, Richland, Washington.

Delaney, C. D., K. A. Lindsey, and S. P. Reidel, 1991, Geology and Hydrology of the Hanford Site: A Standardized Text for Use in Westinghouse Hanford Company Documents and Reports, WHC-SD-ER-TI-0003, Rev. 0, Westinghouse Hanford Company, Richland, Washington.

DOE, 1988, Consultation Draft Site Characterization Plan, DOE/RW-0164, vols. 1-9, Office of Civilian Radioactive Waste Management, U.S. Department of Energy, Washington, D.C.

Fecht, K. R., S. P. Reidel, and A. M. Tallman, 1987, Paleodrainage of the Columbia River System on the Columbia Plateau of Washington State-- A Summary, in Selected Papers on the Geology of Washington, Division of Geology and Earth Resources, J. E. Schuster (editor), Bulletin 77, pp. 219-248.

Freeman-Pollard, J. R., J. A. Caggiano, S. J. Trent, and EBASCO/Hart Crowser, 1994, Engineering Evaluation of the GAO/RCED-89-157 Tank 241-T-106 Vadose Zone Investigation, BHI-00061, Bechtel Hanford, Inc., Richland, Washington.

Gee, G. W., 1987, Recharge of the Hanford Site: Status Report, PNL-6403, Pacific Northwest National Laboratory, Richland, Washington. 
Gephart, R. E., R. C. Arnett, R. G. Baca, L. S. Leonhart, and F. A. Spane, Jr., 1979, Hydrologic Studies Within the Columbia Plateau, Washington: An Integration of Current Knowledge, RHO-BWI-ST-5, Rockwell Hanford Operations, Richland, Washington.

Graham, M. J., M. D. Hall, S. R. Strait, and W. R. Brown, 1981, Hydrology of the Separations Area, RHO-ST-42, Rockwell Hanford Operations, Richland, Washington.

Graham, M. J., G. V. Last, and K. R. Fecht, 1984, An Assessment of Aquifer Intercommunication in the B Pond-Gable Mountain Pond Area of the Hanford Site, RHO-RE-ST-12, Rockwell Hanford Operations, Richland, Washington.

Khaleel, R. and E. J. Freeman, 1995, Variability and Scaling of Hydraulic Properties for 200 Area Soils, Hanford Site, WHC-EP-0883, Westinghouse Hanford Company, Richland, Washington.

Law, A. G., J. A. Serkowski, and A. L. Schayz, 1987, Results of the Separations Area Ground-Water Monitoring Network for 1986, RHO-RE-SR-87-24 P, Rockwell Hanford Operations, Richland, Washington.

Lindberg, J. W., J. V. Borghese, B. N. Bjornstad, and M. P. Connelly, 1992, Geology and Aquifer Characteristics of the Grout Treatment Facility, WHC-SD-EN-TI-071, Westinghouse Hanford Company, Richland, Washington.

Lindsey, K. A., 1991, Revised Stratigraphy for the Ringold Formation, Hanford Site, SouthCentral Washington, WHC-SD-EN-EE-004, 12 p., Westinghouse Hanford Company, Richland, Washington.

Lindsey, K. A., 1995, Miocene-to Pliocene-Aged Suprabasalt Sediments of the Hanford Site, South-Central Washington, BHI-00184, 42 p., 4 Appendices, Bechtel Hanford, Inc., Richland, Washington.

Lindsey, K. A. and A. G. Law, 1993, Geohydrologic Setting, Flow, and Transport Parameters for the Single Shell Tank Farms, WHC Internal Memo 81231-93-060, Westinghouse Hanford Company, Richland, Washington.

Lindsey, K. A., B. N. Bjornstad, J. W. Lindberg, and K. M. Hoffman, 1992, Geologic Setting of the 200 East Area: An Update, WHC-SD-EN-TI-012, Westinghouse Hanford Company, Richland, Washington.

Lindsey, K. A, S. P. Reidel, K. R. Fecht, J. L. Slate, A. G. Law, and A. M. Tallman, 1994a, Geohydrologic Setting of the Hanford Site, South-Central Washington, in Swanson, D.A. and Haugerud, R.A., editors, Geologic Field Trips of the Pacific Northwest: 1994 Geological Society of America Annual Meeting, Dept. of Geological Sciences, University of Washington, Seattle, Washington, p. 1C-1 - 1C-16. 
Lindsey, K. A., J. L. Slate, G. K. Jaeger, K. J. Swett, and R. B. Mercer, 1994b, Geologic Setting of the Low-Level Burial Grounds, WHC-SD-EN-TI-290, Rev. 0, 82 p., Westinghouse Hanford Company, Richland, Washington.

Price, W. H., and K. R. Fecht, 1976, Geology of the 241-AX Tank Farm, ARH-LD-128, Atlantic Richfield Hanford Company, Richland, Washington.

Reidel, S. P., K. A. Lindsey, and K. R. Fecht, 1992, Field Trip Guide to the Hanford Site, WHC-MR-0391, 49 p., Westinghouse Hanford Company, Richland, Washington.

Reidel, S. P., N. P. Campbell, K. R. Fecht, and K. A. Lindsey, 1994, Late Cenozoic Structure and Stratigraphy of South-Central Washington, in Regional Geology of Washington State, R. Lasmais and E.S. Cheney (eds.), Washington Division of Geology and Earth Resources Bulletin 80, Olympia, Washington.

Routson, R. C., and V. G. Johnson, 1990, "Recharge Estimates for the Hanford Site 200 Areas Plateau," in Northwest Science, vol. 64, No. 3.

Tallman, A. M., K. R. Fecht, M. C. Marratt, and G. V. Last, 1979, Geology of the Separations Areas, Hanford Site, South-Central Washington, RHO-ST-23, Rockwell Hanford Operations, Richland, Washington.

Tallman, A. M., J. T. Lillie, and K. R. Fecht, 1981, Suprabasalt Sediments of the Cold Creek Syncline Area, in Subsurface Geology of the Cold Creek Syncline, RHO-BWI-ST-14, C.W. Myers and S.M. Price eds., Rockwell Hanford Operations, Richland, Washington. 
WHC-SD-WM-ANAL-052, Rev. 0

APPENDIX B

HYDRAULIC DATA AND GRAVEL CORRECTIONS

B-i 
WHC-SD-WM-ANAL-052, Rev. 0

\section{CONTENTS}

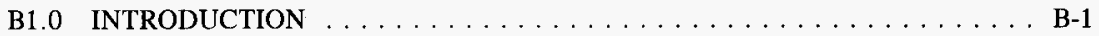

B2.0 ASSIGNMENT OF VADOSE HYDRAULIC PARAMETER VALUES $\ldots \ldots$. . B-1

B3.0 GRAVEL CORRECTIONS $\ldots \ldots \ldots \ldots \ldots \ldots \ldots \ldots \ldots \ldots$ B-3

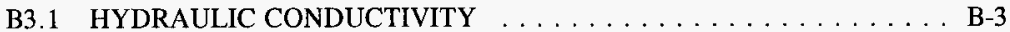

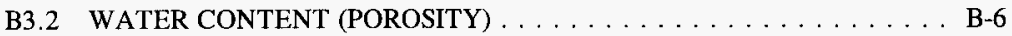

B3.3 MOISTURE RETENTION CURVES $\ldots \ldots \ldots \ldots \ldots \ldots \ldots \ldots$ B-8

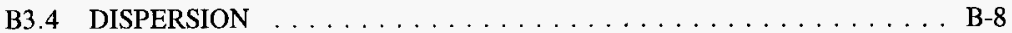

B4.0 REFERENCES . . . . . . . . . . . . . . . . . B-10

\section{TABLES:}

B-1. Hydrogeologic Data for Units Chosen for 241-AX Tank Farm Model . . . . . . B-4

B-2. Data (E25-234 Well, 14.1m Sample) Used in RETC Program . . . . . . . . . . B-9 


\section{B1.0 INTRODUCTION}

This appendix describes the hydraulic data and gravel corrections to the data used in the conceptual models. Because hydraulic data have not been collected explicitly for the 241AX Tank Farm, data from other locations at the Hanford Site had to be chosen and used. Available pore space for water is reduced when gravel is present. The key qualifying assumption is that no large open spaces exist in sediments containing gravel (i.e., no openframework gravel beds). This is expected to be the case for the 241-AX Tank Farm. Because porosity is reduced by the presence of gravel, the fluid from a tank leak has less porosity in which to be held and can be expected to flow through the remaining pore space more rapidly. The fluid flow path becomes more tortuous (and longer) due to the presence of gravel, but this is not expected to sufficiently compensate for the opposite effect resulting from the effect of gravel on porosity. Due to the more tortuous flow paths where gravel is present, the dispersion of any contaminant in the fluid may also be enhanced, particularly in the horizontal direction.

\section{B2.0 ASSIGNMENT OF VADOSE HYDRAULIC PARAMETER VALUES}

Assignment of hydrologic parameter values to the two geologic models followed a stepby-step process described below.

The first step was to determine the physical geologic conditions of the site. This involved interpreting the stratigraphic architecture, grain size and lithology, and interfingering relationships between lithologies. Analogous geologic features where these characteristics are readily described and accessible were identified. Based on these interpretations and data, vadose zone stratigraphy for the 241-AX Tank Farm was inferred. This stratigraphy, which includes known and inferred geologic characteristics, formed the basis for both the simple and detailed vadose zone geologic models. The results of this step constitute the geologic descriptions in Appendix A.

The second step in the process was to determine if any existing vadose zone hydraulic data could be applied to the site. This was done because no site-specific vadose zone hydraulic data were available. Determining the applicability of vadose hydraulic data from other locations focused on finding hydraulic data for sediments similar to those at the 241-AX Tank Farm. These comparisons evaluated similarities in such physical properties as grain size, shape and composition, and stratigraphic unit. If the comparison revealed that samples from other locations came from a lithologic unit which was physically similar a unit identified at the 241-AX Tank Farm, the other data was considered to be applicable.

The final step was assigning vadose zone hydraulic parameter values. The hydraulic parameters of interest included (1) saturated hydraulic conductivity, (2) the parameters (alpha 
and $\mathrm{N}$ ) for the van Genuchten/Mualem moisture characteristic curves used to describe moisture retention and relative permeability, (3) porosity (or, equivalently, bulk density and particle density), and (4) residual moisture content (or saturation). The criteria guiding assignments of these properties are listed below.

Unit 1: Data from the grout performance assessment (Kincaid et al. 1995) were used because of similarities between sandy to gravelly backfill material across the eastern part of the 200 East Area.

Unit 2: Data from grout sample 299-E25-234 $(14.1 \mathrm{~m})$ were used after application of a $25 \%$ gravel correction factor.

Units 3 and 5: Data from grout sample 299-E25-234 (14.1 m) were used after application of a $7 \%$ gravel correction factor.

Units 4.6. and 8: Data from grout sample 299-E25-234 (14.1 m) were used after application of a $30 \%$ gravel correction factor.

Unit 7: Data from grout sample 299-E25-234 $(14.1 \mathrm{~m})$ were used because this sample had grain sizes and textural characteristics similar to the sand-dominated strata of unit 7. The 14.1-m-deep sample was chosen because its Tempe cell (small container used to measure moisture retention) bulk density of $1.61 \mathrm{~g} / \mathrm{cm}^{3}$ resembled the in-situ bulk density of $1.71 \mathrm{~g} / \mathrm{cm}^{3}$; whereas, the other Tempe cell samples had repacked bulk densities that differed appreciably from their in-situ bulk densities. The guiding assumption was that the better and more-representive moisture-retention data were obtained from repacked bulk densities that most closely approximated the in-situ bulk densities.

Unit 9a: Data from project W-049H (sample 2-2865) was used because this sample was from the Ringold lower mud, the same lithology represented by unit 9a. Because the bulk densities were not available in Khaleel and Freeman (1995), the large porosity value of 0.58 was used in this report. After the bulk densities were obtained, it was apparent that the in-situ porosity for this unit was closer to 0.40 . However, after completing a sensitivity analysis with a porosity value of 0.40 , it was determined that fractional release rates to the water table were essentially unchanged. This was mainly because the unit's thickness in the model was only $3.1 \mathrm{~m}$ and conequently did not significantly influence the travel times or release rates. However, because the bulk density $\left(1.1 \mathrm{~g} / \mathrm{cm}^{3}\right)$ of the small sample is not representative of the in-situ bulk density $\left(1.7 \mathrm{~g} / \mathrm{cm}^{3}\right)$, the moisture retention measurements are very much in doubt.

The gravel corrections for units $2,3,4,5,6$, and 8 reflect slightly higher gravel contents in sandy strata at the 241-AX Tank Farm compared to the grout project site. Data from samples (Khaleel et al. 1996) of Hanford formation gravel were not used because of uncertainties regarding bulk density measurements, gravel content, and moisture retention in these samples. Furthermore, sample integrity of these gravels could not be verified. 
The data values for the nine units of the simple (general) geologic model are shown in Table B-1. In addition to the nine units, hydraulic parameter values were chosen to represent the tanks as impermeable objects with a very small porosity of 0.01 .

\section{B3.0 GRAVEL CORRECTIONS}

Many sediments contain gravel (particle sizes ranging from 2 to $75 \mathrm{~mm}$ in diameter). In many cases, undisturbed samples are not available because of the difficulty involved in sampling of gravel or because the lithologic structure was lost in the sampling process. Under these circumstances, samples are often repacked in the laboratory to estimated in situ conditions. Usually, only the finer-grained material $(<2 \mathrm{~mm})$ is used to repack the sample because it is difficult to uniformly repack samples containing gravel. When repacked without gravel, water content (or porosity), water retention characteristics, and hydraulic conductivity values must be corrected. The gravel correction factor is generally a linear or nearly linear reduction of porosity and saturated conductivity, corresponding to the percentage of gravel present under in situ conditions.

It is important to note that repacked samples can provide results which are not representative of in situ conditions, even if the sample is repacked to the same bulk density measured for the in situ sample. The original stratification and structure generally are virtually impossible to recreate when repacking a sample.

Gravel corrections for saturated hydraulic conductivity were made using the method of Bouwer and Rice (1984). Gravel corrections for volumetric water content (or porosity) were also made using the method of Bouwer and Rice (1984), with volumetric gravel content derived from Flint and Childs (1984). These volumetric-water-content (porosity) corrections give the same results as the Gardener method (1986). Details of these methods are discussed in the following sections.

\section{B3.1 CORRECTION OF HYDRAULIC CONDUCTIVITY}

Several techniques are available to correct laboratory-measured hydraulic conductivities for the absence of gravel in a repacked sample. Many techniques differ only with respect to whether the basis of the correction is mass or volume. In the discussion that follows, $\mathrm{V}$ denotes volume fraction, $M$ denotes mass or weight fraction, and the subscripts ' $g$ ', ' $c$ ', and ' $f$ ' signify the gravel component, the fine component, or the composite sample. 
告

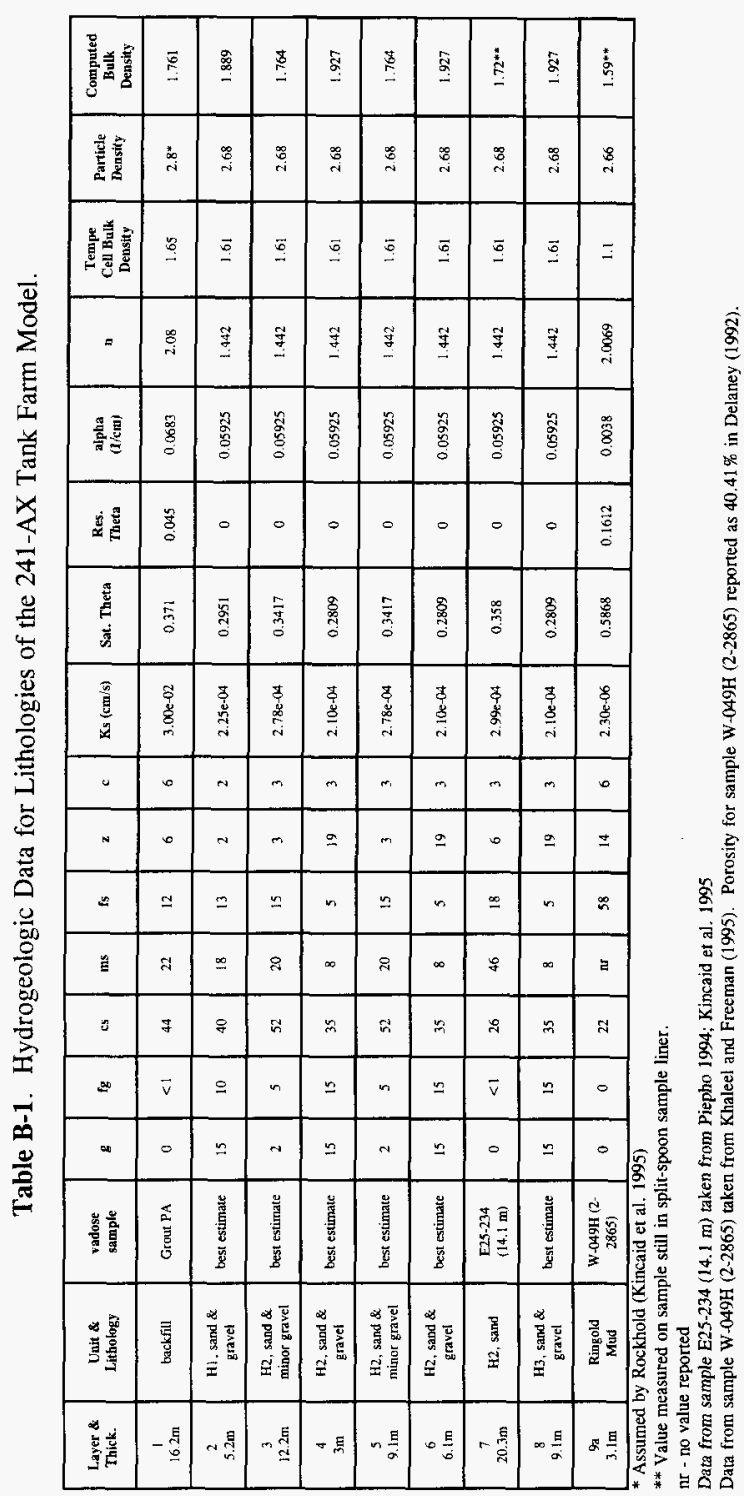


One of the early gravel-correction methods was originated by Peck and Watson (1979). They used a heat-flow analogy and derived the following equation for the ratio of hydraulic conductivity of composite samples for field conditions to the hydraulic conductivity of the fine fraction repacked in the laboratory

$$
K_{c} / K_{f}=2\left(1-V_{g}\right) /\left(2+V_{g}\right)
$$

This method was not chosen, because better methods were subsequently derived.

One method, which is believed to be better and which is used in this report, was developed by Bouwer and Rice (1984) to correct the hydraulic conductivity and water content of repacked soil samples. Large columns were packed with alternating layers of sand and gravel, and the saturated hydraulic conductivities of the columns were measured. An equation that described the relationship between the saturated hydraulic conductivity of the composite material in large columns and that of the sand (fine soil) alone was developed

$$
K_{c} / K_{f}=e_{c} / e_{f}
$$

where $\mathrm{K}_{\mathrm{c}}$ is the hydraulic conductivity of the composite (sand and gravel), $\mathrm{K}_{\mathrm{f}}$ is the hydraulic conductivity of the fine fraction (without gravel), $e_{c}$ is the void ratio of the composite, and $e_{f}$ is the void ratio of the fine fraction.

These void ratios are simply defined as

$$
e_{c}=\theta_{s c} /\left(1-\theta_{s c}\right) \quad e_{f}=\theta_{s f} /\left(1-\theta_{s f}\right)
$$

where $\theta_{\mathrm{sc}}$ is the saturated moisture content (porosity or void fraction) of the composite and $\boldsymbol{\theta}_{\mathrm{sf}}$ is the saturated moisture content (or porosity) of the fine fraction.

Another method was derived by Brakensiek et al. (1986). They simplified the Bouwer and Rice approach because the void ratios of the composite and fine fraction are sometimes laborious to obtain and generally not available. They developed a method to correct saturated hydraulic conductivity using only the mass fraction of the gravel. This information can be obtained easily and in most instances is published in soil survey descriptions. The equation developed by Brakensiek et al. (1986) for estimating corrected hydraulic conductivity is

$$
K_{c} / K_{f}=\left(1-M_{g}\right) /\left(1-M_{g} / 4\right)
$$


The 4 in the denominator of the last term is the assumed ratio of the bulk density of the fine fraction to the bulk density of the gravel. This equation can be further simplified to

$$
K_{c} / K_{f}=\left(1-M_{g}\right)
$$

with the assumption that the denominator in Equation B-4 is approximately 1. This approach is more plausible when using particle size data that are typically obtained on a percentage-ofmass basis. However, that method is more approximate than the Bouwer and Rice (1984) method; hence, it was not used for this report.

\section{B3.2 CORRECTION OF WATER CONTENT (POROSITY)}

Depending on the available laboratory and field data, water content can be calculated several ways. Bouwer and Rice (1984), calculated volumetric water content of bulk soil samples as

$$
\theta_{c}=\left(1-v_{g}\right) \theta_{f}
$$

where $\theta_{c}$ and $\theta_{f}$ are the volumetric water contents of the composite and fine fraction, respectively, and $\mathrm{V}_{\mathrm{g}}$ is the volume fraction of the gravel.

Flint and Childs (1984) expressed the gravel content of soil volumetrically as

$$
V_{g}=\alpha M_{g} /\left[1-M_{g}(1-\alpha)\right]
$$

where $\alpha$ is defined as

$$
\alpha=\rho_{f} / \rho_{g}
$$

where $\rho_{f}$ is the bulk density of the fine fraction, $\rho_{g}$ is the gravel particle density, and $M_{\mathrm{g}}$ is the fraction of total dry mass that is gravel. In this report, the Flint and Childs (1984) equation was used to obtain the volumetric gravel fraction from the mass gravel fraction, which was then used in the Bouwer and Rice (1984) equation to obtain the composite soil porosity.

Another expression was developed by Gardener (1986) that relates volume-based and mass-based water content by the following equation:

$$
\theta_{c}=\left(\theta_{M r} \rho_{c} / \rho_{w}\right) /\left(1+M_{g} / M_{f}\right)
$$


where $\boldsymbol{\theta}_{\mathrm{c}}$ is the volume fraction of water in the composite sample, $\theta_{\mathrm{Mr}}$ is the gravimetric water content (mass) of the fine fraction, $\rho_{c}$ and $\rho_{w}$ are the bulk densities of the composite sample and water, respectively, and $\mathrm{M}_{\mathrm{g}}$ and $\mathrm{M}_{\mathrm{f}}$ are the gravel and fine mass fractions, respectively. The original equation, given by Gardener (1986), uses the ratio of gravel dry mass to the fine dry mass in the denominator, not the mass fractions as in Equation B-9. However, the ratio of the dry masses is equal to the ratio of mass fractions. Hence, Equation B-9 is equivalent to the Gardener equation and the notation is consistent with the rest of this appendix. With no gravel, this reduces to the familiar equation

$$
\theta_{f}=\theta_{M f} \rho_{f} / \rho_{w}
$$

where $\theta_{\mathrm{f}}$ is the volumetric water content of the fine fraction and equals the gravimetric water content times the sample bulk density divided by the density of water. Equation B-10 can be substituted into Equation B-9 to obtain the gravel correction to the moisture content on a volume basis, requiring the bulk densities of the composite and fine fraction, the volumetric water contents of the fine soil and the mass fraction of gravel, as shown in Equation B-11, where the identity $M_{f}=1-M_{g}$ was also used

$$
\theta_{c}=\theta_{f}\left(1-M_{g}\right) \rho_{c} / \rho_{f}
$$

where $\rho_{c}$ and $\rho_{\mathrm{f}}$ are the bulk densities of the composite and fine fraction, respectively. If a composite field sample is not available to measure bulk density, then it can be estimated by the following equation

$$
1 / \rho_{c}=\left(1-M_{g}\right) / \rho_{f}+M_{g} / \rho_{g}
$$

which assumes that the presence of gravel results in no extra air space in the composite sample. If additional air space results from the presence of gravel, then Equation B-12 could still be used to estimate the composite bulk density by substituting the gravel bulk density (gravel mass/volume of gravel and additional air) for the gravel particle density. Equation B-12 can also be used to calculate the porosity of the composite soil, provided the gravel particle density is the same as the fine particle density, by using the following relationship

$$
\theta_{s c}=1-\rho_{\varepsilon} / \rho_{g}
$$

Equation B-11 provides the same gravel correction as Equation B-6 of Bouwer and Rice (1984), provided only soil surrounds the gravel particles and not open air space, as is found in Hanford's open-framework gravel. The equivalence of the two Equations B-6 and B-11 can easily be shown by substituting Equation B-7 for the volumetric gravel fraction into Equation B-6. Another equivalent approach is to use Equations B-12 and B-13 directly to obtain the composite porosity. 


\section{B3.3 CORRECTION OF MOISTURE RETENTION CURVES}

Correcting moisture retention for the absence of gravel in a sample is done simply by adjusting the water contents measured at different pressure heads by one of the above methods. When the water content is corrected for gravel content, the result is that the moisture retention curve is compressed on the axis depicting water content and thereby shifted to lower water contents.

Compression and shifting of the curve changes the curve-fitting parameters determined by means of a numerical curve-fitting program such as RETC (van Genuchten et al. 1991). The saturated and residual moisture contents, $\theta_{\mathrm{s}}$ and $\theta_{\mathrm{r}}$, respectively, scale linearly with respect to the gravel mass fraction. The $\alpha$ and $\mathrm{N}$ parameters are generally less affected. The fine fraction of a sample can generally be expected to have about the same moisture retention capability in the composite sample as it does when separated and measured separately in a Tempe cell, particularly if the bulk densities are the same.

Unsaturated hydraulic conductivity was directly computed from the curve-fitting parameters determined with the RETC program. The program uses a conductivity model developed by Mualem (1976) to predict unsaturated hydraulic conductivities at prescribed pressure-head values. The moisture-content and matric-potential data from the fine fraction sample at $14.1 \mathrm{~m}$ from well 299-E25-234 are shown in Table B-2. This data was used as input for the RETC program, assuming applicability of the van Genuchten/Mualem curves. The results from RETC included an alpha value of $0.05925 / \mathrm{cm}$ and an $\mathrm{N}$ value of 1.44194 . After these values were obtained, the porosity and saturated hydraulic conductivity values were corrected by applying Equations B-2, B-6, and B-7, respectively.

\section{B3.4 CORRECTION OF DISPERSION}

A large volumetric fraction of gravel may increase mechanical dispersion. Mechanical dispersion is due to local variations in water content, tortuosity of flow pathways, and differences in pore-water velocities. Bouwer and Rice (1984), using saturated columns, found an 18-fold increase in dispersion for a sandy soil when they incorporated gravel into the sandy matrix. On the scale of individual pores, variations in water velocity and water potential occurred as flow lines converged between gravel particles.

Dispersion in unsaturated soils is often less than in saturated soils because the larger, high-water-velocity in the former pores are empty. However, this condition is less likely to occur in a coarse gravelly soil near saturation. Near the saturation point in coarse-grained soils, local variations in water potential can result in local saturation. As flow lines converge on a pebble surface, water potential increases locally. This water can be shed from the pebble surface by unsaturated flow along the top surface of the pebble and by saturated flow along the lower surface. In all cases, flow will be focused toward the down-dip end of the pebble, leading to dispersion. If local saturation occurs, variations in pore-water velocity will be larger than in the fully saturated medium. This variation is also reflected in the highly 
Table B-2. Data Used in the RETC Program (E25-234 Well, 14.1m Sample).

\begin{tabular}{|c|c|}
\hline $\begin{array}{c}\text { Potential } \\
(\mathrm{cm})\end{array}$ & $\begin{array}{c}\text { Water Content } \\
(\mathrm{v} / \mathrm{v})\end{array}$ \\
\hline 0.1 & 0.4 \\
\hline 5 & 0.325 \\
\hline 10 & 0.312 \\
\hline 15 & 0.308 \\
\hline 20 & 0.294 \\
\hline 30 & 0.249 \\
\hline 40 & 0.226 \\
\hline 50 & 0.214 \\
\hline 70 & 0.203 \\
\hline 100 & 0.185 \\
\hline 150 & 0.165 \\
\hline 510 & 0.05 \\
\hline 1020 & 0.045 \\
\hline 3060 & 0.03 \\
\hline
\end{tabular}

with Ksat $=2.99 \mathrm{E}-4 \mathrm{~cm} / \mathrm{sec}$.

nonlinear behavior of the unsaturated hydraulic conductivity function as coarse-grained soils approach saturation. The possible result of these vadose zone effects is to increase dispersivity compared to saturated zones.

In general, dispersion at the site of the 241-AX Tank Farm is expected to depend on (1) gravel content, (2) gravel size and shape, (3) recharge and leak volume, and (4) type of lithology. This report did not examine dispersion effects. The dispersion parameters are included in the sixth parameter group (see Section 2.0), which also included the contaminant concentration in the leak volume. Parameters listed in Parameter Group P6 (see Section 2.2) were not varied in this report's analysis because knowledge and resources beyond the scope of this analysis werer needed to perform that analysis. However, these parameters should be included in future sensitivity work, particularly work pertaining to risk assessments. 


\section{B.5 REFERENCES}

Bouwer, H. and R. C. Rice, 1984, "Hydraulic Properties of Stony Vadose Zones," Groundwater 22:696-705.

Brakensiek, D. L., W. J. Rawls, and F. R. Stephenson, 1986, "Determining the Saturated Hydraulic Conductivity of a Soil Containing Rock Fragments," Soil Sci. Soc. Am. J. 50:834-835.

Delaney, C. D., 1992, W-049H Borehole Summary Report, WHC-SD-EN-DP-068, Rev. 0, Westinghouse Hanford Company, Richland, Washington.

Flint, A. L. and S. Childs, 1984, "Physical Properties of Rock Fragments and Their Effect on Available Water in Skeletal Soils," pp. 91-103, In J.D. Nichols et al. (ed.) "Erosion and Productivity of Soils Containing Rock Fragments," Spec. Pub. 13, Soil Sci. Soc. Am., Madison, Wisconsin.

Gardener, W. H., 1986, "Methods of Soils Analysis, Part 1," A. Klute, (ed)., pp.493544., Am. Soc. Agron., Madison, Wisconsin.

Hillel, D., 1994, "Rivers of Eden: The Struggle for Water and the Quest for Peace in the Middle East," Oxford University Press, 355 pp., New York, New York.

Khaleel, R. and E. J. Freeman, 1995, Variability and Scaling of Hydraulic Properties for 200 Area Soils, Hanford Site, WHC-EP-0883, Westinghouse Hanford Company, Richland, Washington.

Kemper, W. D., A. D. Nicks, and A. T. Corey, 1994, "Accumulation of Water in Soils Under Gravel and Sand Mulches," Soil Sci. Soc. Am. J. 58:56-63.

Kincaid, C. T., J. W. Shade, G. A. Whyatt, M. G. Piepho, R. Rhoads, J. A. Voogd, J. H. Westsik, Jr., M. D. Freshley, K. A. Blanchard, B. G. Lauzon, 1995, Performance Assessment of Grouted Double-Shell Tank Waste Disposal at Hanford, WHC-SD-WM-EE-004, Rev. 1, Westinghouse Hanford Company, Richland, Washington.

Knight, J. H., J. R. Philip, and R. T. Waechter, 1989, "The Seepage Exclusion Problem for Spherical Cavities," Water Resour. Res. 25:29-37.

Lemon, E. R., 1956, "The Potentialities for Decreasing Soil Moisture Evaporation Loss," Soil Sci. Soc. Am. Proc. 20:120-125. 
Mehuys, G. R., L. M. Stolzy, J. Letey, and L. V. Weeks, 1975, "Effect of Stones on the Hydraulic Conductivity of Relatively Dry Desert Soils," Soil Sci. Soc. Am. Proc. 39:37-42.

Mualem, Y., 1976, "A New Model for Predicting the Hydraulic Conductivity of Unsaturated Porous Media," Water Resour. Res. 12:513-522.

Peck, A. J., and J. D. Watson, 1979, "Hydraulic Conductivity and Flow in Non-uniform Soil" in Workshop on Soil Physics and Field Heterogeneity, CSIRO Division of Environmental Mechanics, Canberra, Australia.

Philip, J. R., J. H. Knight, and R. T. Waechter, 1989, "Unsaturated Seepage and Subterranean Holes: Conspectus, and Exclusion Problem for Circular Cylindrical Cavities," Water Resour. Res. 25:16-28.

Piepho, M. G., 1994, Grout Performance Assessment Results of Benchmark, Base, Sensitivity and Degradation Cases, WHC-SD-WM-TI-561, Rev. 0, Westinghouse Hanford Company, Richland, Washington.

Stormont, J. C., M. D. Ankeny, and M. K. Tansey, 1994, "Water Removal From a Dry Barrier Cover System. In-Situ Remediation: Scientific Basis for Current and Future Technologies," Part I of the Thirty-third Hanford Symposium on Health and the Environment, G. W. Gee and N. R. Wing, eds. Battelle Press, Columbus, Ohio.

van Genuchten, M. Th., F. L. Leij, and S. R. Yates, 1991, "The RETC Code for Quantifying the Hydraulic Functions of Unsaturated Soils," EPA/500/2-91-065, U.S. Environmental Protection Agency, Washington, D.C. 


\section{ATTACHMENT 1 \\ METRIC CONVERSION CHART}

The following conversion chart is provided to the reader as a tool to aid in conversion.

Into Metric Units

\begin{tabular}{|c|c|c|}
\hline $\begin{array}{l}\text { If You Know } \\
\text { Length }\end{array}$ & Multiply $B y$ & To Get \\
\hline $\begin{array}{l}\text { inches } \\
\text { inches } \\
\text { feet } \\
\text { yards } \\
\text { miles }\end{array}$ & $\begin{array}{l}25.4 \\
2.54 \\
0.305 \\
0.914 \\
1.609\end{array}$ & $\begin{array}{l}\text { millimeters } \\
\text { centimeters } \\
\text { meters } \\
\text { meters } \\
\text { kilometers }\end{array}$ \\
\hline
\end{tabular}

Area

sq. Inches

6.452

sq. teet

sq. yards

sq. miles

acres

0.093

0.836

2.6

0.405

Mass (weight)

ounces

pounds

short ton

28.35

0.454

0.907

Volume

teaspoons 5

tablespoons 15

fluid ounces 30

cups $\quad 0.24$

pints $\quad 0.47$

quarts $\quad 0.95$

gallons

cubic feet

cubic yards

3.8

0.028

0.765

\section{Temperature}

\section{Fahrenheit subtract 32} then multiply by $5 / 9$ ths

sq. meters

sq. meters

hectares

grams

kilograms

metric ton

milliliters

milliliters

milliliters

liters

liters

liters

liters

Celsius
Out of Metric Units If You Know Multiply By To Get Length

millimeters

centimeters

meters

meters

kilometers

0.394

3.281

1.094

0.621

inches

inches

teet

yards

miles

\section{Area}

\begin{tabular}{|c|c|c|}
\hline $\begin{array}{l}\text { sq. centimeters } \\
\text { sq. meters } \\
\text { sq. meters } \\
\text { sq. kilometers } \\
\text { hectares }\end{array}$ & $\begin{array}{l}0.155 \\
10.76 \\
1.196 \\
0.4 \\
2.47\end{array}$ & $\begin{array}{l}\text { sq. Inches } \\
\text { sq. feet } \\
\text { sq. yards } \\
\text { sq. miles } \\
\text { acres }\end{array}$ \\
\hline \multicolumn{3}{|l|}{ Mass (weight) } \\
\hline $\begin{array}{l}\text { grams } \\
\text { kilograms } \\
\text { metric ton }\end{array}$ & $\begin{array}{l}0.035 \\
2.205 \\
1.102\end{array}$ & $\begin{array}{l}\text { ounces } \\
\text { pounds } \\
\text { short ton }\end{array}$ \\
\hline \multicolumn{3}{|l|}{ Volume } \\
\hline $\begin{array}{l}\text { milliliters } \\
\text { liters } \\
\text { liters } \\
\text { liters } \\
\text { cubic meters } \\
\text { cubic meters }\end{array}$ & $\begin{array}{l}0.033 \\
2.1 \\
1.057 \\
0.264 \\
35.315 \\
1.308\end{array}$ & $\begin{array}{l}\text { fluid ounces } \\
\text { pints } \\
\text { quarts } \\
\text { gallons } \\
\text { cubic feet } \\
\text { cubic yards }\end{array}$ \\
\hline
\end{tabular}

sq. centimeters

sq. kilometers

cubic meters

cubic meters

\section{Temperature}

Celsius

multiply by

$9 / 5$ ths, then

Fahrenheit add 32 